Latvijas Lauksaimniecības universitāte

Latvia University of Agriculture

Tehniskā fakultāte

Faculty of Engineering

Izglīî̄ibas un mājsaimniecības institūts

Institute of Education and Home Economics

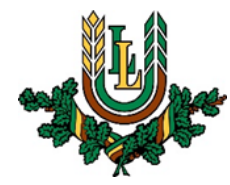

Mg.ed., Mg.oec. Anita Rācene

KARJERAS ATTĪSTĪBA SIEVIETĒM PROFESIONĀLĀS KRĪZES SITUĀCIJĀS MŪŽIZGLĪTĪBAS KONTEKSTĀ

\title{
Career Development for Women in Professional Crisis SituATIONS IN THE CONTEXT OF LIFELONG EDUCATION
}

Promocijas darba KOPSAVILKUMS

Dr. paed. zinātniskā grāda iegūšanai

\section{SUMMARY}

of the Doctoral Thesis for the Scientific Degree of Dr. paed.

Jelgava

2017 
Promocijas darbs izstrādāts Latvijas Lauksaimniecības universitātē laika posmā no 2012. līdz 2016. gadam

\section{Darba zinātniskā vadītāja}

Dr. paed., LLU asociētā profesore Vija Dišlere

\section{Darba recenzenti}

Dr. paed., RPIVA profesore Zenta Anspoka

Dr. paed., LiepU asoc. profesore Ilze Mikselsone

Dr. paed., RTA asoc. profesors Gunārs Strods

LLU pedagogijas zinātnes nozares

Promocijas padomes priekšsēdētāja:

Dr. paed., LLU profesore Baiba Briede

\section{Promocijas darba aizstāvēšana notiks:}

Latvijas Lauksaimniecības universitātes Tehniskās fakultātes Izglītības un mājsaimniecības institūtā, Pedagoǵijas zinātnes nozares promocijas padomes atklātajā sēdē 2017. gada 3. maijā plkst. 11:00 Jelgavā, J. Čakstes bulvārī 5, 502. auditorijā.

Ar promocijas darbu un tā kopsavilkumu var iepazīties:

LLU Fundamentālajā bibliotēkā, Jelgavā, Lielajā ielā 2.

(C) Anita Rācene, 2017

(C) Latvijas Lauksaimniecības universitāte, 2017

Tirāža 60 eks.

DOI: 10.22616/LLUthesis/2017.004 


\section{Saturs}

IEVADS

1. KARJERAS ATTĪSTĪBA SIEVIETĒM MŪŽIZGLĪTĪBAS

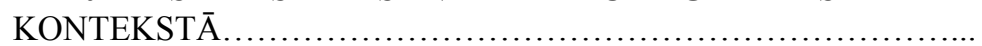

1.1. Karjeras un karjeras attīstības jēdzieniskā izpratne.................. 12

1.2. Mūžizglīî̄bas nozīmīgums karjeras attīstībā sievietēm.................. 14

1.2.1.Pieaugušo izglīîiba mūžizglīîibas kontekstā karjeras attīstībai......... 15

1.2.2.Mūžizglītîbas pasākumu loma karjeras mainai sievietēm............. 16

1.3. Informācijas un komunikācijas tehnolog̣ijas kā karjeras attīstības atbalsta pilnveides līdzekḷi...................................... 17

2. PROFESIONĀLĀS KRĪZES SITUĀCIJU IZVĒRTĒJUMS KARJERAS ATTİSTĪBĀ SIEVIETËM.............................

2.1. Sievietēm piemērojamo karjeras attīstības teoriju izvērtējums............

2.2. Profesionālo krīžu situāciju teorētiska analīze un to noteikšanas kritēriji un rādìtāji......................................................

2.3. Dzimumatbilstīibas principa teorētiskais pamatojums karjeras attīstības problēmu risinājumam sievietēm krīzes situācijās.................. 26

3. VEIDOJOŠAIS EKSPERIMENTS SIEVIEŠU PROFESIONĀLĀS KRĪZES PĀRVARĒŠSANAI..................................... 31

3.1. Pētījuma organizācija un bāzes raksturojums....................... 31

3.2. Profesionālās krīzes pārvarēšanas model̦a un metodikas 33 izstrāde.

3.2.1.Sieviešu karjeras maiñas pētîjumu rezultāti.

3.2.2.Sieviešu karjeru ietekmējošo faktoru pētîjumi...................... 33

3.2.3.Pētījumi par sieviešu karjeras attīstību veicinošām prasmēm.......... 36

3.2.4.Pètījums par profesionālās krīzes noteikšanu pēc kritērijiem un $\quad 38$ rādītājiem........................................................

3.2.5.Pêtījumi par dzimumatbilstības principa ietekmi uz sieviešu $\quad 39$ karjeru......

3.2.6.Diskusija par karjeras mainu sievietēm.

3.2.7.Profesionālās krīzes pārvarēšanas modelis......................... 41

3.2.8.Profesionālās krīzes pārvarēěanas metodikas izstrāde.................... 43

3.3. Profesionālās krīzes pārvarēšanas model̦a aprobācija un 45 ekspertvērtējums.

3.3.1.Profesionālās krīzes pārvarēšanas modeḷa un metodikas ekspertvērtējums.

3.3.2. Klienta attīstošās programmas pētījuma rezultāti karjeras maiņai sievietēm profesionālās krīzes situācijās

SECINĀJUMI

IETEIKUMI. 


\section{Ievads}

Promocijas darba apjoms ir 137 lpp., darbs sastāv no ievada, trīs nodal̦ām, secinājumiem, ieteikumiem un 15 pielikumiem. Teorētisko un praktisko atzinu rezultāti ir attēloti 32 tabulās un 23 attēlā. Kopumā analizēti 244 zinātniskās literatūras un avotu vienības latviešu, angḷu un krievu valodā.

Promocijas darba autore ir beigusi Latvijas Lauksaimniecības universitātes Tehniskās fakultātes Izglīìibas un mājsaimniecības institūta maǵistra studiju programmu Karjeras konsultants un Pedagogijas doktora studiju programmu. Autorei ir 7 gadi pedagogiskā darba pieredze, 5 gadi karjeras konsultēěanas pieredze, kā arī darba stāžs grāmatvedībā un finansēs 24 gadi. Pieredze Eiropas Savienības projektos 5 gadi. Promocijas darba autore strādā Valsts izglītīibas un attīstības aǵentūrā par eksperti - karjeras konsultanti.

Promocijas darbā pētīta problēma par sievietēm profesionālās krīzes situācijās un kā tā varētu tikt pārvarēta ar karjeras atbalstu un izglītošanos. Eiropā ir nodarbināti $63 \%$ sieviešu, salīdzinot ar 76 \% vīriešu nodarbinātību. 2015. gadā Latvijā apmēram četrdesmit sešiem tūkstošiem sieviešu, kuras ir nonākušas profesionālajā krīzes situācijā un palikušas bez darba, ir nepieciešams atbalsts karjeras attīstībā, kas ietvertu gan konsultēšanu, gan izglītojošu programmu.

Mūžizglîtības politika Latvijā balstās uz ideju, ka jāsekmē cilvēka person̄̄go izaugsmi un pašpilnveidi katrā dzīves posmā un visās dzīves jomās mūža garumā, tādējādi radot priekšnosacījumus katra iedzīvotāja uzṇēmības, adaptācijas spēju attīstǐšanai un panākot sociālo iekḷautību, nodarbinātību, aktīvu pilsonisku līdzdalību (Par programmu mūžizglīitības politikas pamatnostādṇu 2007. - 2013. gadam ieviešanai...., 2009; Mūžizglīīības politikas pamatnostādnes 2007. - 2013. gadam, 2007/2009; Mūžizglītības politikas pamatnostādņu 2007. - 2013. gadam īstenošanas gaita..., 2011; 2013).

Mūsdienās ir vērojama tendence, ka pieaugušo izglīî̄bā vispopulārākie ir kursi profesionālās meistarības pilnveidei. Svarīga ir pieaugušo lietpratības dinamika, kritiskās domāšanas attīstība, brīva pašrealizācija, nodrošinot sev pilnvērtīgu funkcionēšanu darba tirgū, kas būtībā ir pieaugušo izglītīibas augstākais uzdevums.

Būtiskākās atšķirības vīriešu un sieviešu starpā vērojamas darba tirgū, kur vīrieši ieņem augstākus amatus un labāk apmaksātus darba tirgus sektorus (stereotips par vīriešiem kā labākiem vadītājiem, kam labāk padodas eksaktās zinātnes). Līdz ar to arī viṇu algas, pensijas un dzīves labklājība ir augstāka nekā sievietēm. Sievietes Latvijā vidēji saņem par $15.4 \%$ zemāku darba algu nekā vīrieši (ES - 17.4 \%). Visās vecuma grupās sieviešu nabadzības risks kopumā ir augstāks nekā vīriešu gan Latvijāa, gan Eiropas Savienībā. Latvijā sieviešu situācija ir krietni sliktāka nekā citu dalībvalstu sievietēm - Latvijā ir visaugstākais sieviešu nabadzības riska rādītājs Eiropas Savienībā - $28 \%$ (Rupenheite, 2010).

Tādēl aktuāls ir kḷuvis jautājums par neformālās izglîtîbas iespējām pieaugušajiem (Adult Education in Europe..., 2015). Autores šî darba misija ir 
sieviešu, kas nonākušas krīzes vai karjeras maiņas situācijās, izglītošanās sekmēšana un karjeras atbalsta sniegšana viņu profesionālās dzīves pilnveidei un attīstībai.

\section{Pētījuma temats}

Karjeras attīstība sievietēm profesionālās krīzes situācijās mūžizglīîibas kontekstā.

\section{Pētijuma objekts}

Karjeras attīstība sievietēm pieaugušo izglītīibā mūžizglītîbas kontekstā.

\section{Pētījuma priekšmets}

Karjeras attīstība sievietēm profesionālās krīzes situācijās.

\section{Pētījuma mērḳis}

Izvērtēt karjeras attīstības iespējas sievietēm profesionālās krīzes situācijās, pamatot un veicināt to pārvarēšanu, izmantojot Profesionālās krīzes pārvarēšanas modeli mūžizglītīibas kontekstā.

\section{Pētijuma jautājumi}

1. Kā mūžizglìtības pasākumi var ietekmēt karjeras attīstību sievietēm?

2. Kādas ir sieviešu profesionālās krīzes situācijas?

3. Kādi profesionālās krīzes noteikšanas kritēriji un rādītāji ir nepieciešami?

4. Kādi faktori ietekmē sieviešu veiksmīgu karjeru?

5. Kā dzimumatbilstības principa ievērošana ietekmē karjeras attīstības problēmu risinājumu sievietēm?

6. Kāds profesionālās krīzes pārvarēšanas modelis nepieciešams sievietēm profesionālās krīzes situācijās?

\section{Pētījuma uzdevumi}

1. Analizēt un izvērtēt zinātnisko literatūru par zinātniskajām pieejām sieviešu karjeras attīstībā un faktoriem, kas ietekmē sieviešu veiksmīgu karjeru mūžizglītības kontekstā.

2. Pētīt profesionālās krīzes situācijas un pamatot pieaugušo izglīitibas nozīmi profesionālās krīzes pārvarēšanā.

3. Teorētiski pamatot dzimumatbilstības principu karjeras attīstības problēmu risinājumam sievietēm profesionālās krīzes situācijās.

4. Izstrādāt, izvērtēt un adaptēt profesionālās krīzes noteikšanas kritērijus un rādītājus.

5. Izstrādāt un zinātniski pamatot profesionālās krīzes pārvarēšanas modeli, atbilstoši tam izstrādāt un ekspertēt sieviešu karjeras konsultēšanas metodiku profesionālās krīzes situācijās.

6. Veikt veidojošo eksperimentu praksē, aprobējot izstrādāto profesionālās krīzes pārvarēšanas modeli, apkopot datus, veikt matemātisko apstrādi, iegūto rezultātu analīzi, salīdzināšanu un izvērtēšanu. 


\section{Pētijuma metodes}

1. Teorētiskās metodes:

- teorētiskās literatūras (pedagoǵijas, psihologijas, karjeras attīstības teorijas, konsultēšanas teorijas) analīze un izvērtēšana;

- normatīivo avotu (LV, ES dokumentu) analīze.

2. Empīiskās metodes. Datu ieguves metodes:

- konstatējošais eksperiments (aptauja, ekspertvērtējums);

- veidojošais eksperiments (eksperiments).

3. Empīiskās metodes. Datu statistiskās apstrādes metodes:

- Grafiskā;

- konkordācijas koeficients (vienprātības) jeb Kendala (M.Kendall) testa $\mathrm{W}$ aprēkins;

- $\chi^{2}$ kritērija, būtiskuma līmeņa aprēķins.

\section{Pētijuma teorētiskais pamats}

Darba teorētiskais pamats veidots, balstoties uz teorijām un atziņām, kā arī starptautiska mēroga dokumentiem par mūžizglītību un karjeras attīstību.

Pieaugušo izglìtībā mūžizglìt̄̄bas kontekstā: M.T. Brauns (Brown), A. Carlsen, R.H. Deivs (Dave), P. Džarvis (Jarvis), E. Karnītis, K.P. Kross (Cross), T. Koḳe, M.S. Nouls (Knowles), D. Lieǵeniece, B.C. Lonstrupa, I. Muraškovska, A. Ouane, V. Vilcāne.

Dzimumatbilstības princips: S. Benhabiba (Benhabib), K. Giligana, K. Krāmere (Kramarae) C.D. Kasla (Kasl), N. Slī (Slee), D. Tanena (Tannen), J.T. Wood.

Sieviešu karjeras konsultēšana: H. Astina, A. Bandura, N. Beca, J. Bimroze, S.D. Brauns (Brown), L. Brauna (Brown), D.A. Koters (Cotter), H. Farmere, R. Fasingere, L. Fitcdžeralde, L. Gotfredsone, Dž. Heketa, Dž. Holands, I. Ķīkule, R. Lents, J.J. Levis (Lewis), A.M. Lopezs (Lopez), B. Lovs, M. Makmahons (McMahon), L. Napikoski, L. Nota, S. Osipovs, V. Patone (W.Patton), R.V. Pīvijs, G. Psathas, J. Rosiers (Rossier), M.L. Savickas, D. Supers, J. Tousainte (Toussaint), L. Veicmane, D. Zitovskis.

Profesionālās krīzes pārvarēšana: G. Ancāne, N.K. Denzin, E. Eriksons, L. Frīmens, K.G. Jungs, K. Kaprino, K. Levins, C.J. Mettlin, M. Peks, J. Rubenis, E. Simaņuks, G. Svence, O.A. Volkova, E. Zejers.

Pétījumu metodologija: I. Arhipova, S. Bāliņa, A. L. Paura.

Normatīvie dokumenti: ES Mūžizglīitibas memorands, Eiropa 2020 Stratēẹija gudrai, ilgtspējīgai un integrējošai izaugsmei, ES Padome rezolūcija, Eiropas Padomes Direktīva, Eiropas Parlamenta un Padomes Direktīva, Eiropas Savienības pamattiesību harta, UNESCO Starptautiskās komisijas ziņojums "Izglītība XXI gadsimtam", Mūžilga karjeras atbalsta politika, Mūžilgs karjeras atbalsts Eiropā, Izglīîibas likums, Mūžizglītības politikas pamatnostādṇu 2007. - 2013. gadam īstenošanas gaita, EMKAPT karjeras atbalsta glosārijs, Latvijas Nacionālais attīstības plāns 2014. - 2020. gadam, Izglīîibas attīstības 
pamatnostādnes 2014. - 2020. gadam, Latvijas ilgtspējīgas attīstības stratēgija līdz 2030. gadam.

\section{Pētījuma bāze}

Pētījuma norises vieta: Nodarbinātības valsts aǵentūras Jelgavas, Bauskas, Dobeles filiāles, tālākizglītības centrs SIA BUTS Bauskas filiāle, sociālie tīkli, piemēram, Draugiem.lv, Facebook.com; Linkedin.com; visidati.lv; e-vide.

Pētījuma dalībnieki: respondenti 1087 - sievietes (gan strādājošas, gan bezdarbnieces, t.sk. profesionālās krīzes situācijās) Latvijā un Lietuvāa, 48 karjeras konsultanti Latvijā, 4 eksperti, 18 veidojošā eksperimenta pētījuma dalībnieces.

Pētījuma norises laiks: 2012. - 2016. gadam.

\section{Pētijuma posmi}

1. posms. (2012-2013). Situācijas izpēte. Nestrukturizēti sieviešu karjeras maiņas novērojumi, personīgās pieredzes refleksija par karjeras maiņu. Ar karjeru, mūžizglîtību, pieaugušo izglìtību un profesionālo krīzi saistītās informācijas apzināšana, apkopošana un izvērtēšana. Karjeras attīstības teoriju, kas piemērojamas sievietēm, izvērtējums. Dzimumatbilstības principa būtības un dimensiju izstrāde. Eksperimenta metodikas izstrādāšana par karjeras maiņu un profesionālajām krīzes situācijām. Pētījums par modernās informācijas komunikācijas tehnologiju izmantošanu karjeras konsultēšanas procesā no 2013. gada aprīḷa līdz 2013. gada maijam.

2.posms. (2013 - 2014). Pētījumi par sieviešu karjeras maiņu, karjeru ietekmējošiem faktoriem un karjeras attīstību veicinošām prasmēm. Anketas izstrāde. Sieviešu anketēšana, pētījums.

3.posms. (2014-2015). Pētîjums par dzimumatbilstības principu sieviešu karjerā no 2014. gada decembra līdz 2015. gada janvārim praktizējošu karjeras konsultantu vidū, lai gūtu priekšstatu par dzimumatbilstîbas principa ietekmi uz sieviešu karjeru. Kritēriju izstrāde dzimumatbilstîbas principa ietekmes noteikšanai uz sieviešu karjeru. Profesionālās krīzes pārvarēšanas modẹ̦a un metodikas izstrāde. Profesionālās krīzes noteikšanas kritēriju un rādītāju izstrāde. Sieviešu aptaujas veikšana no 2015. gada jūnija līdz 2015. gada augustam. Profesionālās krīzes noteikšana pirms eksperimenta, izmantojot izstrādātos kritērijus. Veidojošā eksperimenta veikšana, model̦a aprobācija, metodikas ieviešana. Konstatējošais eksperiments. Ekspertvērtēšanas metodikas izstrāde. Profesionālās krīzes pārvarēšanas modeļa ekspertēšana no 2015. gada jūnija - 2016. gada janvārim, ekspertu novērtējumu apkopojums un analīze. Profesionālās krīzes noteikšana pēc izstrādātajiem kritērijiem pēc eksperimenta ar mērķi noteikt izmaiņas profesionālās krīzes esamībā.

4.posms. (2016). Pētijjuma rezultātu apkopošana un izvērtēšana. Sieviešu aptaujas datu apkopošana, analīze, interpretēšana un izvērtēšana. Secinājumu un ieteikumu izstrāde. 


\section{Pētījuma zinātniskā novitāte}

- Izvērtēts mūžizglīīības nozīmīgums karjeras attīstībā sievietēm profesionālās krīzes situācijās un izvērtētas karjeras konsultēšanas teorijas sievietēm.

- Teorētiski pamatots dzimumatbilstības princips karjeras konsultēšanā sievietēm, kas izsaka sakarību veidošanu starp sieviešu karjeru ietekmējošiem faktoriem, profesionālo krīzi izraisošām situācijām, dzimumatbilstības principa dimensijām un profesionālās krīzes noteikšanas kritērijiem.

- Pamatoti un apkopoti svarīgākie ietekmējošie faktori karjeras attīstībā sievietēm - izglîtības līmenis, brīvo darba vietu skaits dzīves vietā, psiholoǵiskais klimats darba vietā, vadības attieksme, partnera atbalsts.

- Adaptēti profesionālās krīzes noteikšanas kritēriji un rādītāji.

\section{Pētījuma praktiskais devums un nozīmība}

- Izstrādāts Profesionālās krīzes pārvarēšanas modelis sievietēm profesionālās krīzes situācijās. Izstrādāti ieteikumi un pedagog̣iskie risinājumi profesionālās krīzes pārvarēšanai.

- Eksperimentāli aprobēts profesionālās krīzes pārvarēšanas modelis. Sieviešu karjeras maiṇas pētījumu rezultātā izstrādāta, ieviesta un izvērtēta Klienta attīstošā programma karjeras maiņai sievietēm profesionālās krīzes situācijās mūžizglīîibā tiešsaistē.

- Eksperimentāli aprobēta progresīvu metožu izmantošana karjeras konsultēšanā e-porfolio, e-mentorisms, e-konsultēšana.

- Izstrādāti kritēriji dzimumatbilstības principa ievērošanas ietekmes noteikšanai uz sieviešu karjeru.

\section{Pētījuma robežas} iesaistīti:

Model̦a aprobācijā un no 2012. līdz 2016. gadam veiktajos pētījumos tika

- sievietes no Latvijas (909) un Lietuvas (178), bet pētījumu ierobežo tas, ka lielākais respondentu skaits veidojies aizpildot aptauju internetā, tas nozīmē, ka pētījumā nevarēja piedalīties sievietes, kurām nav datorprasmes, nav pieejams dators un interneta pieslēgums. Aptaujas veidlapas aizpildīšana klātienē bija iespējama tām sievietēm, kuras apmeklēja konkurētspējas paaugstināšanas pakalpojumus NVA filiālēs izlases veidā, kurus vadīja autore;

- karjeras konsultanti, kuri strādā NVA un ESF projekta ietvaros;

- eksperti, kuri tika uzaicināti veikt model̦a ekspertīzi.

\section{Tēzes aizstāvēšanai}

1. Karjeras attīstība sievietēm ir dinamisks process, kas ietver sievietes pašrealizāciju gan karjerā, gan gimenē visa mūža garumā, sievietes izaugsmi, tās personīgās īpašības, prasmes, to ietekmējošos faktorus, to 
mijiedarbību un pārmaiņas dzīves visdažādākajās situācijās. Svarīgākie ietekmējošie faktori karjeras attīstībā sievietēm ir izglìtības līmenis, kas tiek pilnveidots izglīîibas programmās mūža garumā, brīvo darba vietu skaits dzīves vietā, psiholoǵiskais klimats darba vietā, vadības attieksme, partnera atbalsts, personīgās īpašības - mērkstiecība, uzņēmība, neatlaidība, prasme tikt galā ar stresu, loǵiskā domāšana un prasmes prasme organizēt savu darbu, prasme strādāt komandā, patstāvīgi pieņemt lēmumus, risināt problēmsituācijas, sadarboties ar citiem cilvēkiem.

2. Dzimumatbilstības princips karjeras konsultēšanā sievietēm izsaka sakarību veidošanos starp sieviešu karjeru ietekmējošiem faktoriem, profesionālo krīzi izraisošām situācijām, dzimumatbilstības principa dimensijām un profesionālās krīzes noteikšanas kritērijiem. Dzimumatbilstības principa ievērošana karjeras konsultēšanā veicina krīzes pārvarēšanu un sekmē karjeras attīstību profesionālā krīzē nonākušām sievietēm.

3. Profesionālās krīzes pārvarēšanas modelis tiek izmantots kā līdzeklis karjeras attīstības veicināšanai profesionālās krīzes situācijās nonākušām sievietēm, realizējot Klienta attīstošo programmu karjeras mainai sievietēm, ievērojot dzimumatbilstības principu gan karjeras izglīitībā, gan karjeras konsultēšanas procesā, gan karjeras atbalstā, rodot iespēju katram klientam izmantot personalizētas e-mācību aktivitātes.

4. Profesionālās krīzes noteikšanas kritēriji un rādītāji ir izmantojami profesionālās krīzes noteikšanai sievietēm pirms un pēc Klienta attīstošās programmas karjeras maiṇai sievietēm profesionālās krīzes situācijās realizācijas.

\section{Pētījuma rezultātu aprobācija}

\section{Referāti zinātniskajās konferencēs}

1. Rācene A. (2016). Sieviešu veiksmīgai karjeras attīstībai nepieciešamās prasmes. Rakstu krājums Izglītības inovāciju un tehnoloğiju konferencē LatSTE'2016 - Karjera digitālajā laikmetā. 25.10.2016. Liepāja: Liepājas Universitāte.

2. Rācene A. (2016). The Model of Career Crisis Management for Women as a Means of Career Development in Relation to Lifelong Education. Report in the 9th International Scientific Conference Rural Environemnt. Education. Personality. Jelgava: LLU.

3. Rācene A. (2016). Factors Influencing Women's Career Change. Report in the 9th International Scientific Conference Rural Environemnt. Education. Personality. Jelgava: LLU.

4. Rācene A. (2015). The Priciple of Gender Conformity in Women's Career Development. Report in the 8th International Scientific Conference Rural Environemnt. Education. Personality. Jelgava: LLU. 
5. Rācene A. (2014). Role of e-Portfolio in Career Education. Report in the International Scientific Conference Social education VII: Children and youth socialization in the postmodern society, Šiauliai, Lithuania: Šiauliai University.

6. Rācene A., Dišlere V. (2014). Internet Tools as a Kind of Career e-Guidance. Report in the 7th International Scientific Conference Rural Environment, Education, Personality, $7^{\text {th }}-8^{\text {st }}$ February, 2014. Jelgava: LLU.

7. Rācene A. (2013). Career Counselling in e-Environment in Latvia. Report in the International Conference New Media for Active Learning in the Digital Age, Šiauliai, Lithuania: Šiauliai University, Distance Studies Centre.

8. Rācene A. (2013). Factors Determining Successful Women Careers. Report in the 6th International Scientific Conferenc Rural Environment. Education. Personality (REEP). Jelgava: LLU.

9. Rācene A. (2012). Women Skills Needed in the Process of Searching for a Job. Report in International Conference Back to Work. The Role of Validation of Competences in Professional Couseling of Adults. Thessaloniki, Greece: Aristotle University of Thessaloniki.

10. Rācene A. (2012). Factors Hindering the Process of Search for Jobs. Report in the 5th International Scientific Conference Rural Environment. Education. Personality. (REEP). Jelgava: LLU.

\section{Publikācijas vispāratzītos zinātniskos recenzējamos izdevumos}

1. Rācene A. (2016). The Model of Career Crisis Management for Women as a Means of Career Development in Relation to Lifelong Education. Proceedings of the 9th International Scientific Conference Rural Environemnt. Education. Personality. Jelgava: LLU, ISSN 2255-808X, pp. 229-238. (Indexed: Thomson Reuters Web of Science; EBSCO Central \& Eastern European Academic Source; AGRIS). Piejams: http://lufb.llu.lv/conference/REEP/2016/Latvia-Univ-Agricult-REEP2016proceed2255-808X.pdf

2. Rācene A. (2016). Factors Influencing Women's Career Change. Proceedings of the 9th International Scientific Conference Rural Environemnt. Education. Personality. Jelgava: LLU, ISSN 2255-808X, pp. 219-228. (Indexed: Thomson Reuters Web of Science; EBSCO Central \& Eastern European Academic Source; AGRIS). Pieejams: http://llufb.llu.lv/conference/REEP/2016/Latvia-Univ-AgricultREEP-2016proceed2255-808X.pdf

3. Racene A. (2016). Pilot Research Results of the Client Developing Programme for Women in Professional Crisis Situations. British Journal of Education, Society \& Behavioural Science, Vol. 14 (3), pp. 1-14. Pieejams: http://sciencedomain.org/issue/1577. DOI: 10.9734/BJESBS/2016/24045

4. Racene A., Dislere V. (2016). Didactic Model of Crisis Management for Women in Professional Crisis Situations. British Journal of Education, 
Society \& Behavioural Science, Vol. 12 (1), pp. 1-16. Pieejams: http://sciencedomain.org/issue/1379. DOI: 10.9734/BJESBS/2016/20619

5. Rācene A. (2015). The Principle of Gender Conformity in Women's Career Development. Proceedings of the 8th International Scientific Conference Rural Environemnt. Education. Personality. Jelgava: LLU, ISSN 2255-808X, pp. 317-328. (Indexed: Thomson Reuters Web of Science; EBSCO Central \& Eastern European Academic Source; AGRIS). Pieejams: http://llufb.llu.lv/conference/REEP/2015/Latvia-Univ-Agricult-REEP2015proceedings.pdf

6. Rācene A. (2014). Development of Women's Career Pattern in Relation of Employment. Baltic Journal of Career Education and Management. Šiauliai, Lithuania: Šiauliai University. ISSN 2345 - 0193, pp. 16-23. Pieejams: http://www.scientiasocialis.lt/bjcem/files/pdf/vol2/1623.Racene bjcem Vol.2-1.pdf.

7. Rācene A. (2014). Role of e-Portfolio in Career Education. Proceedings of the International Scientific Conference Social Education VII: Children and youth socialization in the postmodern society, Šiauliai, Lithuania: Šiauliai University, pp. 281-287. Pieejams: http://content.yudu.com/Library/A32we7/Socialinisugdymas/resources/ 281.htm.

8. Rācene A., Dišlere V. (2014). Internet Tools as a Kind of Career e-Guidance. Proceedings of the 7th International Scientific Conference Rural Environment, Education, Personality. Jelgava: LLU, ISSN 2255-808X, pp. 200-207. (Indexed: Thomson Reuters Web of Science; EBSCO Central \& Eastern European Academic Source; AGRIS) Pieejams: http://lufb.llu.lv/conference/REEP/2014/Latvia-Univ-Agricult-REEP2014proceedings.pdf

9. Rācene A., Dišlere V. (2013). A Career Development Support Programme for Women in Professional Crisis Situations. The European Integration Studies, Vol. 7, pp. 42-50. Lithuania. (Indexed: EBSCO) Pieejams: http://www.eis.ktu.lt/index.php/EIS/article/view/4183

10. Rācene A. (2013a). Career Counselling in e-Environment in Latvia. Research papers and abstracts of international conference New Media for Active Learning in the Digital Age, Šiauliai, Lithuania: Šiauliai University, Distance Studies Centre, pp. 26-39.

11. Rācene A. (2013b). Factors Determining Successful Women Careers. Proceedings of the 6th International Scientific Conferenc Rural Environment. Education. Personality (REEP). Jelgava: LLU, ISSN 2255-808X, pp. 138-145. (Indexed: Thomson Reuters Web of Science; EBSCO Central \& Eastern European Academic Source; AGRIS) Pieejams: http://lufb.llu.lv/conference/REEP/2013/Latvia-UnivAgricult REEP 2013 ISSN 2255-808X.pdf

12. Rācene A. (2012). Women Skills Needed in the Process of Searching for a Job. Medimond International Proceedings Back to Work. The Role of Validation of Competences in Professional Couseling of Adults. Thessaloniki, 
Greece: Aristotle University of Thessaloniki. ISBN-978-88-7587-661-6, pp. 81-86. (Indexed: Thomson Reuters Web of Science). Pieejams: http://www.edlearning.it/proceedings/moreinfo/20121207 index.pdf

13. Rācene A. (2012). Factors Hindering the Process of Search for Jobs. Proceedings of the 5th International Scientific Conference Rural Environment. Education. Personality. (REEP). Jelgava: LLU, ISSN 2255808X, pp. 306-312. (Indexed: Thomson Reuters Web of Science; EBSCO Central \& Eastern European Academic Source; AGRIS) Pieejams: http://llufb.llu.lv/conference/REEP/2012/REEP-2012-proceedings-E-ISSN2255-808X.pdf

\section{Pārējās publikācijas}

1. Rācene A. (2017). Importance of Goal-Setting Tasks in Career Counselling. Proceedings of the 10th International Scientific Conference Rural Environemnt. Education. Personality. Jelgava: LLU. (Akceptēts publicēšanai 13.05.2017).

2. Rācene A. (2016). Sieviešu veiksmīgai karjeras attīstībai nepieciešamās prasmes. Rakstu krājums Izglītības inovāciju un tehnologiju konferencē LatSTE'2016 - Karjera digitālajā laikmetā. 25.10.2016. Liepāja: Liepājas Universitāte, 61. - 69. lpp.

3. Rācene A. (2011) Sieviešu karjeras attīstỉbas teorētiskie aspekti. LLU TF Studentu un maǵistrantu zinātniskā konference, pedagoǵijas zinātņu sekcija 2011. gada 5.maijā, Jelgava. Pieejams: http://www.tf.llu.lv/getfile.php?id=2713

\section{Promocijas darba konspektīvs izklāsts}

Promocijas darba pirmajā nodạ̣ā Karjeras attīstība sievietēm müžizglītības kontekstā pētīti karjeras, karjeras attīstības, mūžizglītības jēdzieni, to nepieciešamība, karjeras attīistības pozitīvā ietekme uz darbu, sadzīvi un sievietes pašapziņu, un vērtību sabiedrībā un gimenē. Pamatota mūžizglītības pasākumu ietekme uz zināšanām, karjeras attīstību sievietēm, kā arī apskatīta pieaugušo izglìtība kā mūžizglìtības sastāvdalı. Izvērtēts mūžizglītības nozīmīgums karjeras attīstībā sievietēm profesionālās krīzes situācijās un izvērtētas karjeras konsultēšanas teorijas sievietēm. Analizēti informācijas un komunikācijas tehnologijas kā karjeras konsultēšanas kvalitātes pilnveides lìdzekḷi. Pirmo nodaḷu veido trīs apakšnodal̦as.

\section{1. apakšnodaḷā Karjeras un karjeras attīstības jēedzieniskā izpratne} tiek skaidroti karjeras un karjeras attīstības jēdzienu dažădu autoru skatījumā, klasificēti pa grupām, kā arī dots autores secinājums.

Ar jēdzienu karjera tiek apzīmēta izaugsme darba un privātās dzīves jomā mūža garumā, un tā skaidrojumi dažādu autoru skatîjumā ir atšķirīgi, tādēl jēdzienu "karjera" zinātnieku skaidrojumus var klasificēt pa grupām. 
1) Karjera tiek definēta kā izaugsme saistībā tikai ar darbu vai politiku izvirzīšanās kādā darbības sfērā, panākumu un slavas sasniegšana (Толочек, 2006); karjera ir personas ar nodarbinātību saistīto amatu, uzdevumu, pasākumu un pieredzes secība (Arnold, 1997).

2) Karjera tiek definēta kā izaugsme saistībā ar mūžizglìtību - karjera tas ir ilgstošs darbs vai profesija ar izredzēm uz attīstības iespējām (Karjeras attīstības atbalsts: izglìtība..., 2008); cilvēka darba pieredzes attīstība laika gaitā (Arthur, Hall, Lawrence, 1989); karjera - personas attīstība mācībās un darbā mūža laikā (Watts, 1998);

3) Karjera tiek definēta, iekḷaujot arī indivīda personīgos dz̄ives izaugsmi un ietekmi - karjera ir jēdziens, kas saistīts ar dzīvesveidu un ietver darba, mācību un brīvā laika nodarbju secību, kuras cilvēks veic sava mūža laikā (EMKAPT karjeras atbalsta glosārijs, 2013); karjera ir dažādu sociāli nozīmīgu, ar darbu, mācībām, pašizteiksmi un brīvā laika nodarbēm saistītu cilvēka uzdevumu secība, kas aptver darba dzìvi, darbavietas, amatus un sasniegumus (EMKAPT karjeras atbalsta glosārijs, 2013). Karjera - darba un privātās dzīves mijiedarbība cilvēka mūža laikā, t. sk. apmaksātā un neapmaksātā darba līdzsvarošana, kā arī līdzdalība mācībās un izglìtībā (EMKAPT karjeras atbalsta glosārijs, 2013).

Apkopojot dažādu karjeras teoriju skatījumu, autore secina, ka karjera ir apzināta cilvēka mērkstiecīga darbība savu personisko un profesionālo mērksu sasniegšanai visa mūža garumā.

Karjeras attīstība tiek definēta kā mācīšanās, darba un citu personīgi nozīmīgu pašapliecināšanās veidu attīstības process mūža garumā (Karjeras attīstības atbalsts: izglīīiba.., 2008).

Karjeras attīstība tiek definēta arī kā ekonomisku, socioloǵisku, psihologisku, fizisku, izglītības un nejaušības faktoru kopums, kas veido indivīda karjeru (Sears, 1982).

Karjeras attīstību mūsdienās vairums zinātnieku raksturo kā dinamisku procesu, kas ietver indivīda pašrealizāciju, vidi, mijiedarbību, pārmaiņas. Karjeras attīstība ne vienmēr nozīmē augšupeju, ir iespējama arī karjeras lejupslīde, vai karjeras attīstība plašumā. Karjeru pieaugušā vecumā ietekmē esošā posma dzīves loma.

Tā kā karjeras attīstības līmenis katram indivīdam ir dziļi personisks, vienam pietiek ar vienkāršu darbu ilgstošā periodā, kuram nav nepieciešama augsta kvalifikācija, bet citam ir vēlme izglītoties un ieņemt arvien augstākus un atbildīgākus amatus, līdz ar to var teikt, ka pašrealizācijas vajadzības cilvēkiem l̦oti atšķiras, tās ir loti individuālas un laika gaitā main̄̄gas, tāpēc autore nepievērsās īpašu karjeras attīstības rādītāju izstrādei, bet gan profesionālās krīzes situāciju analīzei un kritēriju izstrādei krīzes noteikšanai.

Apkopojot analizētās teorētiskās atziņas, autore secina, ka karjeras attīstība sievietēm ir pašrealizācija gan karjerā, gan gimenē visa mūža garumā, ievērojot ekonomiskos, sociālos, psihologiiskos un fiziskos karjeru ietekmējošos faktorus. 
Darba autore savā pētījumā pievēršas karjeru ietekmējošo faktoru izpētei sievietēm, personīgajām īpašībām un prasmēm, noskaidrojot pašas svarīgākās, kuras ietekmē un veicina veiksmīgu karjeras attīstību sievietēm.

\section{2. apakšnodaḷā Mūžizglīî̉bas nozīmīgums karjeras attīstībā sievietēm,} balstoties uz dažādu autoru zinātniskajām publikācijām, promocijas darba autore skaidro un pamato mūžizglītības nozīmi karjeras attīstībā sievietēm.

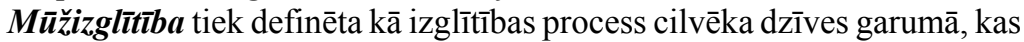
balstās uz mainīgām vajadzībām iegūt zināšanas, prasmes, pieredzi, lai paaugstinātu vai mainītu savu kvalifikāciju atbilstoši darba tirgus prasībām un savām interesēm un vajadzībām.

Mūžizglīî̄ba apvieno neformālo mācīšanos ar formālo izglìtīibu, attīsta iedzimtas spējas līdztekus jaunām kompetencēm (Mūžizglītības politikas pamatnostādnes..., 2007/2009).

Mūžizglìtība ir visas mācību darbības, kas veiktas dzìves laikā, kuru rezultātā personīgu, sabiedrisku vai profesionālu iemeslu dēl tiek uzlabotas zināšanas, tehnologiskā kompetence, iemaņas, prasmes un kvalifikācija (EMKAPT karjeras atbalsta glosārijs, 2013).

Autore secina, tā kā karjeras attîstība notiek mūža garumā un mūžizglīitība ir process mūža garumā, tad abi jēedzieni ir saistīti. Karjeras attīstība iespējama izglītojoties, pilnveidojot savas prasmes un personības izaugsmi, kas savukārt iespējams mūžizglītībā piedāvātajos kursos un programmās, līdz ar to liela nozīme sieviešu karjeras attīstībā ir mūžizglītībai.

Dokumentā Eiropa 2020 izvirzītas prioritātes: veicināt ilgtspējīgu, iekḷaujošu izaugsmi, kas balstās uz augstu nodarbinātības līmeni un noteikts mērksis, ka līdz 2020. gadam samazināt to cilvēku skaitu, kam draud nabadzība. Latvijas Nodarbinātības Valsts aǵentūrā uzskaitē 2015. gada marta beigās reǵistrētas bija 46240 sievietes, un sieviešu nodarbinātības līmenis Latvijā ir zemāks, nekā vīriešu nodarbinātības līmenis, kas pierāda, ka sievietēm ir visvairāk nepieciešamas karjeras konsultācijas un karjeras attīstības atbalsts, kas ietvertu gan konsultēšanu, gan izglìtojošu programmu. Autore to piedāvā šajā promocijas darbā, apkopojot visu atbalsta pasākumu kopumu.

Mūžizglīîība tiek aplūkota kā vienots veselums, kas sākas no cilvēka piedzimšanas brīža un turpinās līdz mūža beigām. Individuālā motivācija mācīties un dažādas izglītības iespējas ir galvenie faktori, lai sekmīgi īstenotu mūžizglîtīibu. Mūžizglītības nepārtrauktajā procesā lielāka loma ir neformālām mācībām, kura notiek ārpus skolām, koledžām, un augstskolām.

M.S. Nouls (M. Knowles) pētot neformālo izglītību, secina, ka vislabāk izmantot grupu un forumu pieejas organizējot neformālo izglītību.

Eiropas Savienības (turpmāk tekstā ES) Izglītības padomes divas Rezolūcijas (no 2004. un 2008. gada) ir pamatojušas nepieciešamību pēc stabiliem karjeras atbalsta pasākumiem cilvēka mūža garumā, lai nodrošinātu personas ar prasmēm vadīt savu izglītošanās procesu un karjeras izveidi, kā arī 
pāreju no viena izglītības un/vai darba cēliena uz nākamo. Rezolūcijas ir koncentrējušas uzmanību uz četrām prioritātēm:

- karjeras vadības prasmju izveide,

- karjeras atbalsta pakalpojumu pieejamība,

- karjeras pakalpojumu kvalitātes nodrošinājums,

- pakalpojumu saskaņotības koordinēšana (Resolution of the Council..., 2010; Mūžilga karjeras atbalsta politika: darbs turpinās, 2011; Mūžilgs karjeras atbalsts Eiropā..., 2011).

Autore secina, ka cilvēka attīstība notiek mūžizglîtības rezultātā, un mūžizglìtīiba - tā ir iespēja sevi izglītot, nodarbināt, paplašināt redzesloku, būt sabiedrībā un būt apmierinātam ar sevi un rezultātā iespēja rast atbilstošu darbu savai izglītîbai un prasmēm vai uzsākt pašnodarbinātību. Autoresprāt, mūžizglīitība jāsaprot kā izglīî̄iba cilvēka mūža garumā. Tā balstās uz iekšèju vajadzību vai ārēju faktoru izraisītu nepieciešamību iegūt un arvien papildināt savas zināšanas un prasmes. Mūžizglìtība ar īpaši organizētu gan formālo, gan neformālo izglìitības sistēmu, sekmē pilnvērtīgu personības attīstību un l̦auj cilvēkam veiksmīgāk pielāgoties jaunajām laikmeta un sociālajām pārmaiņām un, nemitīgi paaugstinot savu kvalifikāciju vai pat pārkvalificējoties, nezaudēt darbu.

Mūžizglīî̄ba nozīmē iegūt izglîtību un zināšanas visas mūža garumā, neatkarīgi no vecuma un izglītības vai sociālā stāvokḷa, līdz ar to Latvijā aktualizējas pieaugušo izglītīiba, kas saistīta ar lielo bezdarba pieaugumu.

Apakšnodaḷā 1.2.1. Pieaugušo izglītỉba müžizglītības kontekstā karjeras attīstībai autore pamato pieaugušo izglìtības aktualitāti un nozīmīgumu.

Pieaugušo izglītība tiek definēta kā personu daudzveidīgs izglītošanās process, kas cilvēka mūža garumā nodrošina personas attīstību un konkurētspēju darba tirgū (Izglītîbas likums, 1999).

Kā norāda T. Koḳe (Koḳe, 1999) 20. gadsimta astoṇdesmito gadu sākumā K.P. Kross (Cross,1981) jēdzienus "nepārtrauktā izglītîba" un "pieaugušo izglìtība" lietoja kā sinonīmus. Tāpat arī 80. un 90. gadu mijā M.S. Nouls (Knowles, 1988) nesaskatīja īpašas atšķirības starp jēdzieniem "pieaugušo izglītība", "nepārtrauktā izglîtīiba" un "tālākizglìtība", uzsverot, ka būtiska un kopēja izglītības iezīme ir tās nepārtrauktība.

UNESCO Starptautiskās komisijas ziņojumā "Izglīîiba XXI gadsimtam" (Learning the Treasure within, 1996) tiek runāts par četriem pīlāriem, uz kuriem balstīsies izglîtība visa mūža garumā:

- mācīšanās zināt;

- mācīšanās darīt;

- mācǐšanās dzīvot kopā;

- mācīšanās būt.

Pieaugušo izglìtība sievietēm var palīdzēt apgūt jaunas iemaņas vai labāk izprast apkārtni, kā arī uzlabot dzīvi un paplašināt tās robežas, kā arī kursu dalībnieki ir trenējuši savas spējas būt kopā un sadarboties ar citiem. 
Pieaugušajiem aktualizējas profesionālās meistarības un lietpratīibas pilnveidošanas nepieciešamība, lai uzlabotu savas karjeras attīstību darba vietā. Nevis pašas zināšanas un prasmes ir mērkis profesionālās pilnveides izglīīībā, bet gan profesionālās meistarības un lietpratības dinamika un tas, kā cilvēks to prot izmantot, nodrošinot sev pilnvērtīgu funkcionēšanu darba tirgū.

Vissarežǵîtākais ir novērtēt iekšêjās kvalitatīvās izmaiņas personības izpratnē, vērtībās, attieksmēs, pārliecībā. Šādi novērtěšanas un pašvērtējuma pañēmieni sekmē cilvēku kritiskās domāšanas attīstību, refleksiju, brīvu, humānu pašrealizāciju, kas plašākā kontekstā ir demokrātijas pamatu stabilizācijas priekšnosacījums, kas būtībā ir pieaugušo izglītības augstākais uzdevums.

D. Lieǵeniece (2002), balstoties uz M.S. Noula (Knowles, 1988) atzin̄ām, secina, ka pieaugušie kḷusst gatavi mācīties, kad viņi izjūt vajadzību zināt vai kaut ko darīt, lai efektīvi pārveidotu kādu savas dzīves aspektu. M.S. Nouls (Knowles, 1988) ir norādījis, ka pieaugušo gatavība mācīties ir saistīta ar sekojošiem faktoriem:

- izpratni par to, ko viniem vajag zināt,

- orientāciju uz reālām problēmām vairāk nekā uz mācību priekšmetiem,

- iekšēju motivāciju mācīties.

Pozitīivu rezultātu mūžizglîtība dod, ja cilvēks iegūtās zināšanas var izmantot darbā, sadzìvē un līdz ar to vairojas cilvēka pašapziṇa un vērtība sabiedrībā.

Apakšnodaḷā 1.2.2. Mū̌̆izglītības pasākumu loma karjeras mainai sievietēm autore pamato mūžizglītības lielo pasākumu un iespēju lomu, ietekmi, pien,emot lēmumu karjeras maiņai, apkopotas iespējas, kā iegūt jaunas prasmes.

Karjeras attīstība sievietēm ir sarežg̀îtāka nekā vīriešiem, jo pastāv vairākas iekšējās un ārējās barjeras, tostarp, ǵimenes pienākumi, dzīves loma, nodarbinātība, apkārtējā vide, tradīcijas, stereotipi, kas ierobežo sieviešu karjeras izvēli, karjeras izaugsmi vai karjeras mainuu.

Pamatojoties uz zinātnieku P. Džarvis (Jarvis), A. Carlsen, E. Karn̄̄ša, T. Koķes, I. Muraškovskas, A. Ouane, V. Vilcānes atziņu analīzi var secināt, ka mūžizglītība ar īpaši organizētu gan formālo, gan neformālo izglītības sistēmu, sekmē pilnvērtīgu personības attīstību un l̦auj sievietēm veiksmīgāk pielāgoties jaunajām laikmeta un sociālajām pārmaiņām, un, nemitīgi paaugstinot savu kvalifikāciju vai pārkvalificējoties, ļauj nezaudēt darbu vai veiksmīgi veikt karjeras mainu.

Mūsdienās, kad darba tirgus situācija strauji mainās, daudzās nozarēs ienāk jaunas tehnolog̣ijas, līdz ar to pieaug prasības pret strādājošiem, rodas nepieciešamība pēc profesionālo spēju pilnveidošanas un zināšanu pārstrukturēšanas. Ja cilvēks netiek līdzi jaunajām prasībām, vinšs kḷūst par bezdarbnieku, kas nav izdevīgi sabiedrības ilgtspējīgai attīstībai. Mūžizglītīiba ir veids, kā valstiskā līmenī šo problēmu risināt holistiski, kā cilvēki tās ietvaros var papildināt savas zināšanas visa mūža garumā, neatkarīgi no vecuma, esošās izglīitības vai sociālā stāvokḷa. Mūžizglîtības ietvaros arī sievietēm, lai 
nodrošinātu iespēju izdzīvot jebkurā dzīves situācijā un rastu jaunas perspektīvas, ir jāpilnveidojas, jāuzlabo savas profesionālās spējas, jāmaina savas attieksmes, vērtības un pārliecība personības kvalitatīvas izaugsmes izpratnē. Profesionālās meistarības pilnveides mūžizglītỉbas dažādi neformālās izglītības kursi, ko profesionālajā krīzē nonākušas sievietes apmeklē iekšēju vajadzību vai ārēju faktoru ietekmē, sniedz iespēju paplašināt redzesloku, sekmē cilvēku kritiskās domāšanas attīstību, refleksiju, personības autonomiju, brīvu, humānu pašrealizāciju. Plašākā kontekstā skatoties, iepriekšminētās kvalitātes ir demokrātijas pamatu stabilizācijas priekšnosacījums, kas būtībā ir mūžizglītības augstākais uzdevums. Mācoties, pilnveidojoties un tādejādi attīstoties, vairojas cilvēka pašapziņa un vērtība sabiedrībā, kas ir ceľ̦s uz pilnvērtīgu, gandarījumu sniedzošu dzīvi, kas balstās uz apmierinātību darbā un personiskajā dzīvē. Tā rezultātā rodas cilvēku, kas mācās mūža garumā, lietpratības pastāvīga pozitīva dinamika, kas ir priekšnoteikums pilnvērtīgai funkcionēšanai darba tirgū, kas arī ir pamats visas sabiedrības ilgtspējīgai attīstībai. Tādejādi mūžizglītība dod iespējas krīzē nonākušām sievietēm realizēt savus mērķus, iegūt izglītību, uzlabot prasmes, līdz ar to paveras daudzveidīgas iespējas pašrealizācijai karjeras tālākai attīstībai.

\section{3. apakšnodaḷā Informācijas un komunikācijas tehnologíjas kā} karjeras attīistības atbalsta pilnveides līdzekli izvērtētas iespējas kā modernizēt un uzlabot karjeras attīstības atbalsta pakalpojumus un pilnveidotu vai apgūtu jaunas prasmes sievietèm, izmantojot karjeras atbalsta pakalpojumus.

Līdz ar straujo informācijas un komunikācijas tehnologijas attīstību, un e-mācību ieviešanu augstskolās, vidusskolās, kursos, aktuāla ir kḷuvusi e-konsultācijas izmantošana karjeras attīstības atbalsta procesā. Ieviešot virtuālo tiešsaisti karjeras attīstības atbalsta procesā, mērķis būs palīdzēt cilvēkiem, kuriem nepieciešams uzlabot prasmes, iegūt nepieciešamo informāciju un saņemt atbalstu no karjeras konsultanta un konsultācijas, informācijas resursus, interaktīvos novērtēšanas līdzekḷus var saņemt jebkurā laikā un jebkurā dienā (Karjeras atbalsta pasākumi..., 2010).

IKT kompetence ir kḷuvusi par būtisku vispārējās kompetences indikatoru. Karjeras attīstības atbalsta sistēma sastāv no trim galvenajiem pamatelementiem:

- informācija (sagatavošana un sniegšana);

- karjeras izglïtība (pakalpojumi, kursi, programmas);

- karjeras konsultācijas (palīdzība karjeras plānošanā, profesionālās piemērotības noteikšana, darba izmēǵinājumi, darba meklēšanas un darbā noturēšanās prasmju apguve) (Koncepcija karjeras attīstības atbalsta sistēmas ..., 2006).

E-mācības l̦auj jebkāda veida tradicionālās mācības pārnest elektroniskā vidē, tās var sastāvēt no video, audio, tekstuāliem materiāliem, kā arī no animācijas un datora ekrāna simulācijām. E-mācību programmas un procesi ietver tiešsaistē balstītu mācīšanos, datorizētas mācības, virtuālās klases iespējas 
un digitālo sadarbību, kurās mācību saturs tiek piegādāts, izmantojot internetu (gan iekštīkla, gan ārtīkla), audio vai video, satelīta TV un CD. Mācības var tikt organizētas gan pašmācības cel̦ā, gan instruktora vadībā un ietver mediju formā tekstus, attēlus, animācijas, dažāda veida video un audio materiālus. (Elearningcompanion.com, 2015).

Tiešsaistes pakalpojumi sniedz jaunas iespējas izglītībā. Internets kḷūst par mācību līdzekli, kā arī paplašina iespējas strādāt (Guthrie, McCracken, 2010).

E-konsultēšana ir konsultēšana jeb atbalsts, kas tiek sniegts, izmantojot IKT, un kurā var būt vai nebūt tieši iesaistīts karjeras atbalsta konsultants. E-konsultēšana ietver karjeras atbalsta darbību, izmatojot visas IKT formas:

- karjeras atbalsts tiešsaistē;

- karjeras atbalsts pa tālruni;

- karjeras atbalsts internetā.

Informācijas un komunikācijas tehnologijas karjeras atbalstam ir tehnolog̣ijas, kas nodrošina informācijas elektronisko ievadīšanu, uzglabāšanu, iegūšanu, apstrādāšanu, kā arī nosūtīšanu un izplatīšanu.

Vispārīgi informācijas un karjeras attīstības atbalsta pakalpojumi tīmeklī aptver virkni informācijas pasniegšanas modalitāšu: vienkārša vai strukturēta hiperteksta informatīvās lapas; lejupielādējamas datnes; datu bāzes; multimediju resursi.

No 2013. gada aprị̣̄a līdz 2013. gada maijam tika veikts pētījums praktizējošu karjeras konsultantu vidū, lai gūtu priekšstatu, kā karjeras konsultants izmanto modernās informācijas komunikācijas tehnologijas karjeras attīstības atbalsta procesā. Aptaujā piedalījās 42 praktizējoši karjeras konsultanti, vecumā no 24 līdz 60 gadiem. Karjeras attīstības atbalstu, izmantojot informācijas un komunikācijas tehnologijas, veica 37 no aptaujā piedalījušo karjeras konsultantu skaita. Aptaujas mērķis bija informācijas komunikācijas tehnologiju izmantošanas izpēte karjeras attīstības atbalsta procesā. Pētījuma rezultāti bija šādi.

- Karjeras attīstîbas atbalsts ar IT palīdzību paplašina konsultēšanas iespējas, sniedz papildus informāciju, klientam ir iespēja saņemt ātras atbildes uz neskaidriem jautājumiem.

- Praktizējošie karjeras konsultanti Latvijā karjeras attīstības atbalsta procesā visbiežāk izmanto e-pasta vēstules (28), tad internetu (18), tālruni (16), karjeras pakalpojumus attālināti nesniedz (12) un citu variantu (7).

- praktizējošie karjeras konsultanti visbiežāk tomēr neizmanto interneta vietnes karjeras konsultēšanā, tas izskaidrojams ar to, ka trūkst informācijas un prasmju šo vietņu izmantošanā, labās prakses piemēri. 10 respondenti atzina, ka izmanto citas vietnes, kā piemēram - skype, draugiem.lv, facebook.com, e-klase, skolas iekštikls, www.viaa.gov.lv, www.nva.gov.lv, inbox.lv, e-klase.lv. 7 karjeras konsultanti atzina, ka izmanto vietni www.pbworks.com, šie konsultanti strādā LU PPMF ESF projekta ietvaros, kur tika izmantota šĩ vietne, un 1 respondents atzina, ka izmanto vietni moodle.com. 
- Analizējot respondentu atbildes, var secināt, ka, priekšrocības karjeras konsultēšanai e-vidē ir šādas: 1.vietā iespēja saņemt karjeras konsultācijas un piedalīities grupu nodarbībās neatkarīgi no atrašanās vietas, 2.vietā karjeras konsultēšana notiek abām pusēm pieejamā laikā, 3.vietā zemākas izmaksas - klientiem nav jābrauc uz karjeras centru, lai saņemtu konsultāciju, 4.vietā karjeras konsultanta uzdevumi, dod iespēju klientam patstāvīgi uzlabot prasmes, zināšanas un risināt savas problēmas, 5.vietā IKT prasmju apgūšana karjeras konsultēšanas procesā.

- Pēc respondentu atbildēm kā svarīgākie trūkumi karjeras konsultēšanai e-vidē: 1.vietā minēts, ka nav tiešais kontakts karjeras konsultantam ar klientu, 2.vietā - trūkst tieša un tūlîtēja atgriezeniska saite no karjeras konsultanta, 3.vietā klientiem trūkst zināšanas un prasmes darbā ar datoru un jaunajām tehnologijām, 4.vietā karjeras konsultēšana vietnē kavē ātru informācijas apmaiņu. 5.vietā karjeras attīstības atbalsta process var ieilgt klienta neizdarības dēl vai arī konsultācija var palikt bez rezultāta.

\section{Promocijas darba otrajā nodạ̄ā Profesionālās krīzes situāciju} izvērtējums karjeras attīst̄̄bā sievietēm izvērtêtas sievietēm piemērojamās karjeras attīstības teorijas. Teorētiski analizētas piecas pieejas karjeras attīstībā sievietēm, izpētìtas profesionālās krīzes situācijas un teorētiski pamatots dzimumatbilstības princips karjeras attīstībā sievietēm un izstrādāti profesionālās krīzes noteikšanas kritēriji un rādītāji. Otro nodaļu veido trīs apakšnodalas.

\section{1. apakšnodaḷā Sievietēm piemēerojamo karjeras attīstības teoriju} izvērtējums analizètas zinātnieku atzin̄as par piecām pieejām karjeras attīstībā sievietēm un aplūkotas autores izvēlètas karjeras attīstības teorijas, kuras var piemērot profesionālajā krīzē nonākušu sieviešu karjeras atbalstam.

Sieviešu karjeras attīstību pētījuši dažādi autori. Dž. Holands (Holland, 1973) sieviešu karjeras attīstību atzina kā l̦oti līdzīgu vīriešu karjeras teorijai. D. Supers (Super, 1957, Super, 1980; Super, 1990) savos karjeras izaugsmes posmos ietver arī sieviešu karjeras attīstību. S. Osipovs (Osipow, Littlejohn, 1995) savukārt atzīmē karjeras teoriju nespēju skaidrot sieviešu karjeru kā atsevišksu grupu. L.E. Izaksone (Isaacson) un S.D. Brauns (Isaacson, Brown, 1993) norāda sievietes kā atsevišķu "īpašu grupu”, kas ir ārpus esošajām teorijām. V. Patone (Patton) un M. Makmahons (McMahon) (Patton, McMahon, 2006) analizē ekoloǵiskos un starpkultūru aspektus sieviešu karjeras attīstībā. J. Bimrose atzīmē, ka sievietes un vīrieši tiek vērtēti atšķirīgi, un analizē veidus, kā sievietēm veiksmīgi iekḷauties darba tirgū (Bimrose, 2008). C. Čens pievērš uzmanību konsultēšanas specifikai sievietēm, kā tikt galā ar darbu un gimenes pienākumiem nekonfliktējot (Chen, 2008). L. Belangers piedāvā piemērus, kā sievietēm iesaistîties biznesā un būt veiksmīgām (Belanger, 2015). M.B. Arthur, D.T. Hall, B.S. Lawrence, A.B. Rochlen, D.P. Bloch analizē karjeras teorijas kopumā, kā arī 
aplūko dažādus iemeslus, faktorus un saistības, kā veicināt sieviešu karjeras attīstību (Arthur, Hall, Lawrence, 2008; Bloch, 2005; Applying counseling theories, 2007). Turpmāk aplūkotas piecas pieejas karjeras attīstībā sievietēm.

Pirmā pieeja - sieviešu karjeras atsevišķu teoriju veidošana. Tās izveidi pamato atšķirīgās vajadzības, perspektīvas, izvēles, prioritātes un karjeras veidi. Tādi faktori kā laulības, gandarījums, ğimenes finanses, sociālā piederība, vecāku izglītîba un nodarbošanās, vērtības, sociālā mobilitāte un draugu izvēle sievietēm izpaužas atšķirīgi nekā vīriešiem.

D. Zitovskis (Zytowski, 1969/2011) izdala trīs sieviešu nodarbinātîbas faktorus: darba uzsākšanas vecums; darbā pavadītais laiks; darbā iesaistǐšanās pakāpe.

Otrā pieeja - esošo teoriju adaptācija. D. Supers (Super, 1957) izdala septiņus sieviešu karjeras veidus:

- stabilas mājsaimnieces;

- tradicionālā karjera;

- stabila nodarbinātība; sievietes strādā algotu darbu visu dz̄ivi;

- paralēlais karjeras veids; sieviete apvieno algotu darbu ar darbu mājsaimniecībā;

- pārtrauktais karjeras veids;

- nestabilais nodarbinātības veids; neregulāra iesaistīšanās darbā;

- jauktais karjeras veids.

Autore D. Supera teoriju ir iekḷāvusi Klienta attīstošās programmas nodarbību sastāvā, kā arī izveidots mājas darbs sievietēm, kurā ir uzdevums izanalizēt savu karjeras veidu pēc D. Supera septiniem sieviešu karjeras veidiem.

Dž. Holands (Holland, 1973; Holland, 1985; Holland 1994), aprakstot sešus cilvēku tipus un tiem atbilstošo nodarbinātību, uzskata, ka starp cilvēku interešu sistēmu un viņu darbošanās spējām ir cieša saistība (Karjeras konsultēšanas metodes, 2009).

Trešā pieeja - visaptverošu sieviešu un vīriešu karjeras teoriju veidošana. L. Gotfredsone (Gottfredson, 1981) un H. Astina (Astin, 1984) izveido teorijas abu dzimumu karjerai. H. Astina (1984) apvieno motivāciju, darba lomu gaidas, dzimuma lomas socializāciju un iespēju struktūras. Savukārt L. Gotfredsone (1981) pauž atziṇu, ka personības struktūras veidošanos ietekmē dzimums, sociālā grupa, inteliǵence, intereses, vērtības un to mijiedarbība ar priekšstatiem par nodarbinātību.

Ceturtā pieeja - saistās ar specifisku, individuāli atšķirīgu sieviešu karjeras izvēles izpēti. H. Farmere (Farmer, 1997) izvirza teoriju, kas saista izcelšanās faktorus (dzimums, rase, sociālais slānis, skolas atrašanās vieta, vecums) ar personas psiholoǵiskajiem (pašvērtējums, vērtības, attieksme pret mājām, sasniegumu uztvere) un vides faktoriem (sabiedrības attieksme pret sieviešu darbu, skolotāju un vecāku atbalsts).

Piektā pieeja - sieviešu karjerai piemērojamu sociāli kognitīvo modeļu veidošana. Zinātnieces Dž. Heketa un N.E. Beca (Hackett, Betz, 1981; Hackett, 1995) mēǵina izskaidrot socializācijas ietekmi uz karjeras veidošanu, izmantojot 
A. Banduras (Bandura, 1977) definētos personas pašpārliecības rādītājus: sasniegumu uzrādī̌sana, citu pieredzes izmantošana, saņemts verbāls iedrošinājums, emocionāls pacēlums (augstākajā pakāpē kā cenšanās, zemākā kā pašpārliecība).

Autore izmanto otro pieeju par esošo teoriju adaptēšanu sievietēm un piekto pieeju par sociāli kognitîvo modeḷu izmantošanu sieviešu profesionālo krīžu pārvarēšanā, klienta attīstošās programmas izstrādei.

Tālāk aplūkotas autores izvēlētas karjeras attīstības teorijas, kuras var piemērot krīzē nonākušu sieviešu karjeras atbalstam.

Profesionālās ierobežotības teorija. Saistībā ar sieviešu karjeru, to attīstību un ierobežotību tiek lietota frāze stikla griesti (angl. the glass ceiling). Profesionālās ierobežotības teorija atbilst ceturtajai karjeras attīstības pieejai.

Stikla griesti politikas plānošanas dokumentos tiek apzīmēts ar terminu vertikālā darba tirgus segregācija - vīriešu un sieviešu tendence ieņemt atšķirīgus amatus tajā pašã profesijā vai profesiju grupā (Ķîkule, 2006).

J. Tousainte savos pētījumos uzskata, ka stikla griesti nozīmē sieviešu ekonomisko apspiešanu (Toussaint, 1993). Frāze stikla griesti attiecas uz neredzamu barjeru, kas neḷauj sievietēm turpināt gūt panākumus karjerā. Šì metafora visbiežāk tiek lietota saistībā ar sievietēm, kuras nevar pakāpties pa karjeras kāpnēm savā darbavietā. Teorētiski jau it kā nekas netraucē veidot šo augšupejošo karjeru, barjeru uzliek stereotipi, līdz ar to izskaidrojums, ka griesti ir no stikla.

Stikla griesti ietver barjeras karjeras vertikālai izaugsmei, nevienlīdzīgas darba samaksas par vienu un to pašu paveikto darbu, profesionalitāties zaudēšanu uz grūtniecības un dzemdību atvalıinājuma laiku.

Parasti darba vietā diskriminācija notiek vairāku būtisku faktoru ietekmē - vecums, dzimums, tautība, tādēl ir grūti nodalīt tieši to diskrimināciju, kas vērsta pret darbinieku tādēl, ka viņš ir vīrietis vai sieviete (Ķīkule, 2006).

Latvijas Republikā likumdošana paredz vienādu attieksmi pret vīriešiem un sievietēm. Stikla griestu parādību ir grūti regulēt tikai ar likumdošanas palīdzību, jo tas lielā mērā saistīts ar sabiedrības izpratni, stereotipiem par dzimumu lomām.

Kopienas mijiedarbības teorija. Kopienas mijiedarbības teorijas pamatā kā noteicošo faktoru profesijas izvēlē uzskata cilvēka mainīgo dzīvi un personību kopumā, vietējās starppersonu saites, kas vinu vieno ar svarīgiem cilvēkiem, apstākḷu kopējā struktūra (Wolfe, Kolb, 1980).

Teorija apskata sabiedrības ietekmi uz indivīda lēmumu pieņemšanas procesu. B. Lovs noteica piecus galvenos veidus, kādā minētā ietekme notiek:

- lomu gaidas (cerības) - lēmumi tiek pieņemti, pamatojoties uz to, kas tiek uzskatīts par pieņemamu ǵimenes vai kopienas grupām;

- atgriezeniskā saite - informācija, ko cilvēki saņem, par profesijas izvēles stiprām un vājām pusēm, kā arī to piemērotību konkrētiem mērksiem;

- atbalsts - stiprināt un attīstīt nepieciešamās prasmes;

- modelēšana - ietekmīgu piemēru pieejamība un identifikācijas pakāpe ar citiem, domājot par darbu; 
- informācija - iespējas uzzināt par dažādām iespējām.

Koncentrējoties uz šo ideju, pētot klienta kopienas, sabiedrības vai gimenes ietekmi uz karjeras veidošanu, šñ teorija palīdz konsultantiem atbrīvoties no aizspriedumiem un labāk izprast to, kā klienti veidojuši savu karjeru un kā sniegt palīdzību turpmāk.

Rasu, etniskie un kultūras aspekti karjeras attīstībā. Rasu un etnisko grupu karjeras teorijas iedala trijās kategorijās. Tradicionālās teorijas, kas:

1) ietver arī minoritāšu aspektus Dž. Holands, D. Supers (Holland, 1973; Holland, 1985; Super, 1957, Super, 1980; Patton, McMahon, 2006);

2) plašāki teorētiskie modelii, kas piemērojami dažādās kultūrās:

- pašpārliecības (self-efficacy) teorija Dž. Heketa, N.E. Beca (Hackett, Betz, 1981; Hackett, 1995);

- sociāli kognitīvais modelis R. Lents, Dž. Heketa (Bandura, 1986; Lent, Brown, Hackett, 1994, 2000, 2002);

- karjeras izvēles sociālās mācīšanās teorija Dž. Krumbolcs (Krumboltz, 1994; Osipow, Fitzgerald, 1996; Mitchell, Krumboltz, 1996; Sharf, 2006; Krumboltz, 2006; Bimrose, 2016);

- sociālpsihologiskais modelis L. Gotfredsone (Gottfredson, Lapan, 1997; Gottfredson, 1981; Gottfredson, 2002; Hauser, Tsai, Sewell, 1983);

- sistēmteorija, starpkultūru perspektīvas V. Patone (Patton), M. Makmahons (McMahon) (Patton, McMahon, 2006);

- dzīves dizaina paradigma karjeras attīstībā M.L. Savickas, L.Nota, J. Rosiers (Savickas, Nota, Rossier, 2009).

3) teorētiskie mēǵinājumi ievērot kultūras specifiku:

- mazākuma/ minoritāšu karjeras attīstība, nevis rases atšķirības (Osipow, Littlejohn, 1995);

- saistībā ar karjeru ierosina lietot jēdzienus etniskā grupa un kultūras grupa, jo jēdzieni rase, etniskā piederība, minoritāte mūsdienu sociālkultūrā ir izplūduši un grūti precīzi atdalāmi (Leong, Brown, 1995).

Lai pārbaudītu praksē, kā darbojas šīs teorijas, kā teorētiskās atzinas efektīvāk izmantot sieviešu karjeras attīstības atbalstam, un iepazīstināt sievietes ar sieviešu karjeras attīstības teoriju daudzveidīgumu, tika veikti pētījumi sieviešu vidū, kas detalizētāk aprakstīts 3.nodaḷā.

\section{2. apakšnodaḷā Profesionālo krī̌̆u situāciju teorētiska analīze un to} noteikšanas kritēriji un rādītäji tiek pētīta profesionālās krīzes situācijas, dots profesionālo krī̌u raksturojums personības attīstības procesā, raksturoti profesionālās krīzes cēloṇi un faktori, apkopotas galvenās profesionālās krīzes saistībā ar sievietes vecumposmu, kā arī autore ir atlasījusi un adaptējusi profesionālās krīzes noteikšanas kritērijus un rādītājus izmantojot E.F. Zejera (Э.Ф.Зеер) un E.E. Simaņuka (Э.Э. Симанюк) teorētiskās atziņas, apkopojusi 
kritērijus, kas izriet no dzimumatbilstības principa dimensijām, pēc kuriem tika veikts pētījums ar karjeras konsultantiem, sievietēm par dzimumatbilstības principa ievērošanas ietekmi uz sieviešu karjeru.

Krīze karjerā ir kā profesionālās attīstības krīze, ko izraisa (Denzin, Mettlin, 1972; Волкова, 2005):

- procesi, kas saitīti ar indivīda vecumu;

- profesionālās attīstības destrukcijas;

- jaunības periodā identitātes krīze var izraisīt profesionālo krīzi, izpausmes;

- profesionālā krīze var būt saistīta ar personības identitāti, ja personība objektīvi nespēj veikt profesionālu pārorientēšanos un nonāk konfliktā ar agrāko profesionālo identitāti;

- krīzi var izraisīt nepilna profesionalizācija;

- krīzi izraisa situācija, kurā referentā profesionālā grupa nav gatava pieņemt konkrēto indivīdu;

- emocionālā izdegšana tiek uzskatīta par profesionālo krīzi, jo izpaužas kā attieksmes izmaiņa pret darbu un profesiju.

K.G. Jungs (Юнг, 1996) uzsver, ka konstruktīvā izeja no krīzes ir individualizācija - pašattīstība, paštapšana.

Jebkuras krīzes gadījumā norit izmaiņas, un tās paver iespējas attīstībai. Krīzes veiksmīgas pārvarēšanas nosacījumi pēc M. Peka ir (Пек, 1996):

- emocionāls lokanums, emocionāls atbalsts bērniem un saviem vecākiem;

- dzīves plānu/ mērķu reālu izvērtēšana,

- dzīves laika ierobežotības apzināšanās;

- dzīves veida korekcija;

- jauna Es tēla izveide;

- sava stāvokḷa pieņemšana kā normāla, tāda, kurš veicina stabilitāti.

Saistībā ar vecumposmiem profesionālās krīzes sievietēm apkopotas 1. tabulā. Autore profesionālo krīzi raksturo kā situāciju karjerā, kad nepieciešamas pārmaiņas profesijas izvēlē vai maiṇā, vai nodarbinātības statusa maiņā (no darbinieka par uzṇēmēju), kuras pārvarēšanai tiek piedāvāts karjeras konsultanta un mentora atbalsts, kura detalizēts apraksts apkopots profesionālā krīzes pārvarēšanas modelī . 
Galvenās profesionālās krīzes saistībā ar sievietes vecumu

\begin{tabular}{|c|l|l|}
\hline $\begin{array}{c}\text { Vecum- } \\
\text { posmi }\end{array}$ & \multicolumn{1}{|c|}{ Krīze } & \multicolumn{1}{|c|}{ Raksturojošais krīzei attiecībā uz darba tirgu } \\
\hline $19-20$ & $\begin{array}{l}\text { Profesionāāās } \\
\text { izvēles krīze (3eep, } \\
\text { Симанюк, 2005) }\end{array}$ & $\begin{array}{l}\text { Mācību profesionālās darbības motīvu maiņa. } \\
\text { Profesijas izvēle un tās korekcija. Prakses trūkums, } \\
\text { kas apgrūtina darba atrašanu. }\end{array}$ \\
\hline $40-45$ & $\begin{array}{l}\text { Psiholoğiskā un un } \\
\text { fizioloğiskā krīze } \\
\text { sievietēm (Svence, } \\
\text { 2003). }\end{array}$ & $\begin{array}{l}40-45 \text { gadus vecu sieviešu dzīvē var sākties jaunas } \\
\text { izjūtas par sevi kā personību, sieviete var iegūt, } \\
\text { piemēram, izjūtu, ka "beidzot esmu es pati un man } \\
\text { nav bail, ko domās citi ". Sievietes atkal uzsāk ko } \\
\text { jaunu, kaut ko maina, vai izglīitību un profesionālo } \\
\text { karjeru. }\end{array}$ \\
\hline $60-62$ & $\begin{array}{l}\text { Pirmspensijas } \\
\text { profesionālā krīze }\end{array}$ & Apgrūtināta darba atrašana, maiņa, darba zaudēšana. \\
\hline
\end{tabular}

Avots: autores konstrukcija

Autore ir atlasījusi un adaptējusi profesionālās krīzes noteikšanas kritērijus un rādītājus izmantojot E.F. Zejera (Э.Ф.Зeep) un Е.Е. Simaņuka (Э.Э. Симанюк) teorētiskās atziņas (skat. 2. tab.). Kritērijs tiek definēts, kā pazīme, pēc kuras kaut ko novērtē, definē vai klasificē (AkadermTerm, 2016d). Profesionālās krīzes noteikšanas kritēriji ir pazīmes ar kuru palīdzību var novērtēt vai esošā situācijā ir vai nav profesionālā krīze sievietei. Kā rādīiājus, cik lielā mērā konkrētais kritērijs ir izteikts sievietei noteiktā situācijā, tiek izteikti ballēs no $1-5.1$ balle - stipri izteikts negatīvs vērtējums (pilnībā nepiekrītu), 2 balles - izteikts negatīvs vērtējums (nepiekrītu), 3 balles - neitrāls vērtējums (neitrāli), 4 balles - izteikts pozitīvs vērtējums (piekrītu), 5 balles - stipri izteikts pozitīvs vērtējums (pilnībā piekrītu).

2. tabula

Profesionālās krīzes noteikšanas kritēriji un rādītāji

\begin{tabular}{|c|l|c|c|c|c|c|}
\hline Nr. & \multicolumn{2}{|c|}{ Kritēriji } & \multicolumn{4}{|c|}{ Rādītāji } \\
\hline 1 & $\begin{array}{l}\text { Manā dzīvē profesionālā karjera } \\
\text { man ir nozīmīga. }\end{array}$ & 1 balle & 2 balles & 3 balles & 4 balles & 5 balles \\
\hline 2 & $\begin{array}{l}\text { Es spēju realizēt profesionālos } \\
\text { nodomus. }\end{array}$ & 1 balle & 2 balles & 3 balles & 4 balles & 5 balles \\
\hline 3 & $\begin{array}{l}\text { Esmu apmierināta ar } \\
\text { profesionālo izglīīību. }\end{array}$ & 1 balle & 2 balles & 3 balles & 4 balles & 5 balles \\
\hline 4 & $\begin{array}{l}\text { Esmu apmierināta ar } \\
\text { profesionālo sagatavotību. }\end{array}$ & 1 balle & 2 balles & 3 balles & 4 balles & 5 balles \\
\hline
\end{tabular}


2. tabulas turpinājums

\begin{tabular}{|c|c|c|c|c|c|c|}
\hline Nr. & Kritēriji & & & Rādītāji & & \\
\hline 5 & $\begin{array}{l}\text { Man ir profesionālās } \\
\text { adaptācijas grūtības. }\end{array}$ & 1 balle & 2 balles & 3 balles & 4 balles & 5 balles \\
\hline 6 & $\begin{array}{l}\text { Man ir jaunu vadošo darbību } \\
\text { apguves grūtîbas. }\end{array}$ & 1 balle & 2 balles & 3 balles & 4 balles & 5 balles \\
\hline 7 & $\begin{array}{l}\text { Man ir profesionālo gaidu } \\
\text { nesakritîba ar reālo îstenību. }\end{array}$ & 1 balle & 2 balles & 3 balles & 4 balles & 5 balles \\
\hline 8 & $\begin{array}{ll}\text { Esmu apmierināta } & \text { ar savām } \\
\text { profesionālās } & \text { izaugsmes } \\
\text { iespejā̄m. } & \end{array}$ & 1 balle & 2 balles & 3 balles & 4 balles & 5 balles \\
\hline 9 & $\begin{array}{l}\text { Man ir vajadzība pēc } \\
\text { profesionālās pašnoteikšanās. }\end{array}$ & 1 balle & 2 balles & 3 balles & 4 balles & 5 balles \\
\hline 10 & $\begin{array}{l}\text { Man ir grūtības profesionālās } \\
\text { pašnoteikšanās īstenošanā. }\end{array}$ & 1 balle & 2 balles & 3 balles & 4 balles & 5 balles \\
\hline 11 & $\begin{array}{l}\text { Man ir jauna profesionālo } \\
\text { vêrtîbu dominante. }\end{array}$ & 1 balle & 2 balles & 3 balles & 4 balles & 5 balles \\
\hline 12 & $\begin{array}{l}\text { Esmu neapmierināta ar iespējām } \\
\text { realizēt sevi izveidojušajās } \\
\text { profesionālajās situācijās. }\end{array}$ & 1 balle & 2 balles & alles & 4 balles & 5 balles \\
\hline 13 & $\begin{array}{l}\text { Esmu neapmierināta ar savu } \\
\text { sociāli profesionālo statusu. }\end{array}$ & 1 balle & 2 balles & 3 balles & 4 balles & 5 balles \\
\hline 14 & $\begin{array}{l}\text { Es jūtu profesijas } \\
\text { psihofizioloğiskās izmaiņas un } \\
\text { veselības pasliktināšanos. }\end{array}$ & 1 balle & 2 balles & 3 balles & 4 balles & 5 balles \\
\hline 15 & $\begin{array}{l}\text { Manā profesionālajā darbā man } \\
\text { nav skaidrības par ko esmu } \\
\text { atbildīgs. }\end{array}$ & 1 balle & 2 balles & 3 balles & 4 balles & 5 balles \\
\hline 16 & $\begin{array}{l}\text { Manā profesionālajā darbā es } \\
\text { uzņemos arvien vairāk un } \\
\text { vairāk pienākumu, nekā jebkad } \\
\text { spēšu paveikt, jo nemāku } \\
\text { pateikt "nē". }\end{array}$ & 1 balle & 2 balles & 3 balles & 4 balles & 5 balles \\
\hline 17 & 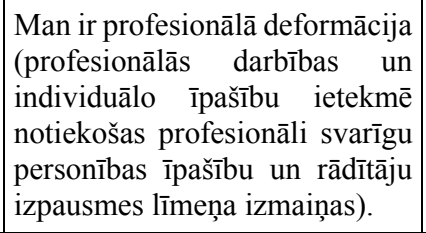 & 1 balle & 2 balles & 3 balles & 4 balles & 5 balles \\
\hline
\end{tabular}

Autores konstrukcija, adaptēts pēc (Зеер, Симанюк, 2005) 
Profesionālo krīzi izraisa nespēja realizēt profesionālos nodomus, profesionālās adaptācijas grūtības, neapmierinātība ar sociāli profesionālo statusu, jaunu darbību apguves grūtības, veselības pasliktināšanās. Profesionālās krīzes noteikšanas kritēriji un rādītāji tiks izmantoti pētījumā, anketējot respondentus pirms un pēc veidojošā eksperimenta, lai noskaidrotu vai autores piedāvātais profesionālās krīzes pārvarēšanas modelis ir devis gaidītos rezultātus.

2.3. apakšnodaḷā Dzimumatbilstības principa teorētiskais pamatojums karjeras attīstības problēmu risinäjumam sievietēm krī̄es situācijās ir izpētītas dzimumu komunikāciju teorijas un teorētiski pamatots dzimumatbilstības princips karjeras attīstību problēmu risinājumam sievietēm profesionālās krīzes situācijās.

Pastāv uzskats, ka indivīdiem ir ierobežota izvēle profesijas un nodarbinātības ziņā saistībā ar dzimumu, etnisko un sociālo piederību.

Sieviešu un vīriešu līdztiesības stratēgijā ir uzsvērts dzimumu līdztiesības ieguldījums ekonomiskajā izaugsmē un ilgtspējīgā attīstībā un atbalstīita dzimumu līdztiesības dimensijas iekl̦aušana stratēǵijā "Eiropa 2020". Viens no stratēǵijas pamatmērķiem ir nodarbinātības līmenim iedzìvotāju grupā no 20 līdz 64 gadiem no pašreizējiem 69 \% būtu jāpieaug vismaz līdz $75 \%$, tostarp izmantojot sieviešu lielāku nodarbinātību (Eiropa 2020. Stratēǵija gudrai, ilgtspējīgai un integrējošai izaugsmei, 2010). Tomēr dzimumu atšksirības joprojām pastāv un darba tirgū sievietes vēl joprojām ir vairāk pārstāvētas zemāk apmaksātajās nozarēs, bet nepietiekami pārstāvētas amatos, kuros tiek pieņemti lēmumi. Vidējais dzimumu līdztiesības indekss Eiropas Savienībā ir 54 (1 nozīmēe, ka nav dzimumu līdztiesība un 100 dzimumu līdztiesība ir sasniegta pilnībā). Latvijā tas ir zemāks nekā ES vidējais - 44.4. Dzimumu līdztiesības indekss parāda vidējos rādītājus šādās dzimumu līdztiesības jomās: nodarbinātîba, ienākumi, zināšanas, laiks, vara un veselība.

Jebkurā jomā, kurā vērojama atšķirīga sieviešu un vīriešu situācija, cēlonis ir sabiedrības stereotipi par viena vai otra dzimuma lomu, uzvedību, izskatu, prāta spējām. Mūsu pieņēmumi par sievišķību un vīrišķību ietekmē saskarsmi gan ǵimenē, gan darbavietā un apkārtējā sabiedrībā, tāpēc komunikāciju teorijas, kas skaidro sieviešu un vīriešu komunicēšanas atšķirības, varētu būt ḷoti noderīgas veiksmīgas karjeras veidošanas procesu izpratnei (skat. 3. tab.). 
Dzimumu komunikācijas atšḳirības

\begin{tabular}{|c|c|c|}
\hline Nr. & Teorijas & Galvenās pamatidejas \\
\hline 1 & \begin{tabular}{l}
\multicolumn{1}{c}{ Dzimumu } \\
komunikāciju \\
stili \\
(Tannen, \\
1990/2007; \\
Tannen, \\
1992a; \\
Tannen \\
1992b)
\end{tabular} & 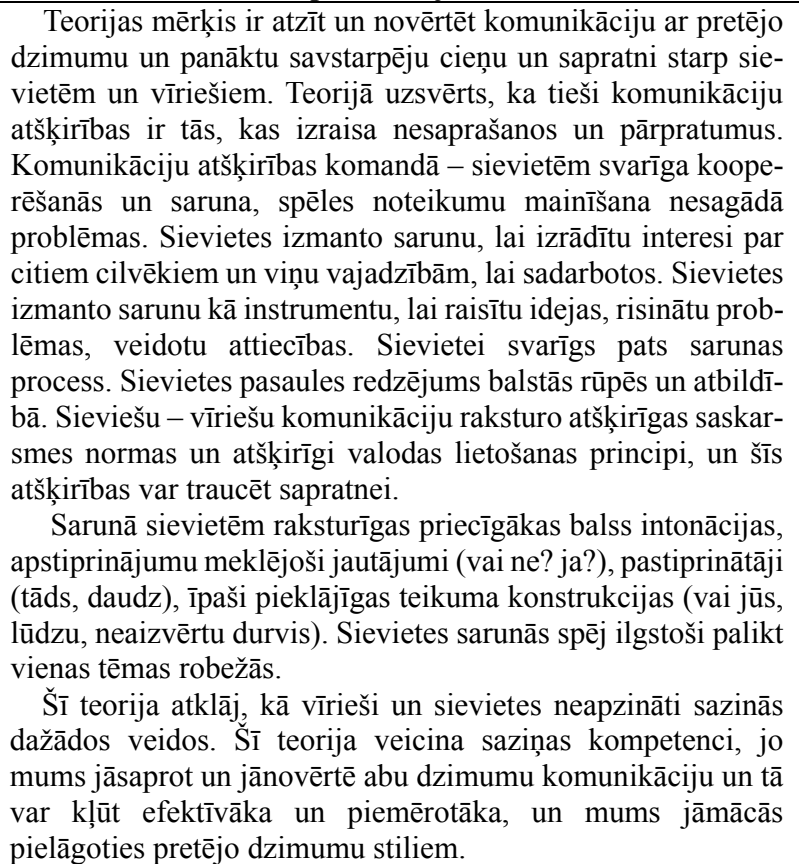 \\
\hline 2 & $\begin{array}{l}\text { Klusējošo } \\
\text { grupu } \\
\text { teorija } \\
\text { (Kramarae, } \\
\text { 1996a; } \\
\text { Kramarae } \\
\text { 1996b; } \\
\text { Ardener, } \\
\text { Ardener, } \\
\text { 2005) }\end{array}$ & 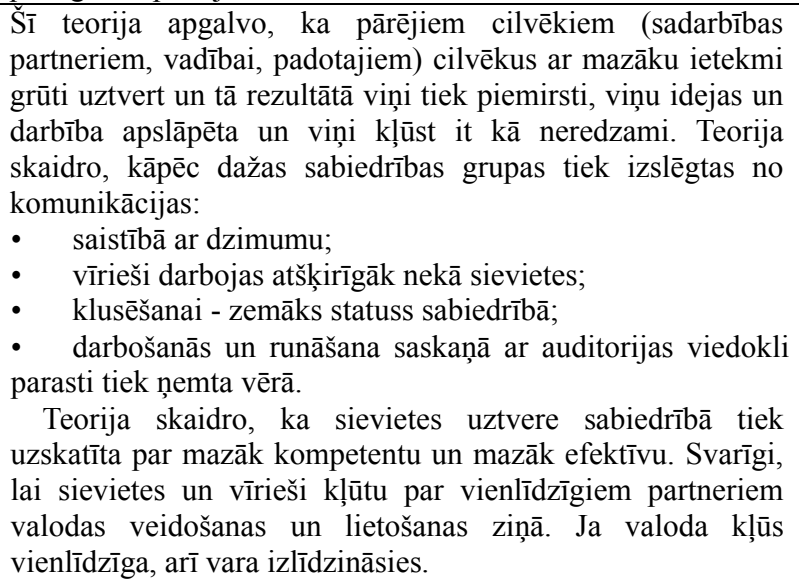 \\
\hline
\end{tabular}


3. tabulas turpinājums

\begin{tabular}{|c|c|c|}
\hline Nr. & Teorijas & Galvenās pamatidejas \\
\hline 3 & $\begin{array}{l}\text { Interaktīvā } \\
\text { universālisma } \\
\text { teorija } \\
\text { (Benhabib, } \\
\text { 1992) }\end{array}$ & 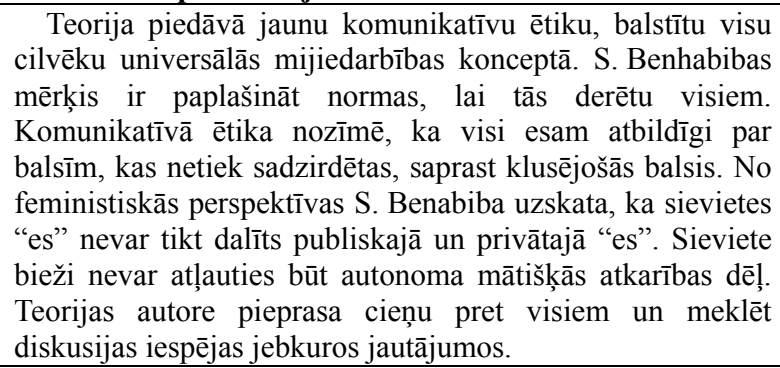 \\
\hline 4 & $\begin{array}{l}\text { Objektivitātes } \\
\text { (viedokḷa) } \\
\text { teorija } \\
\text { (Standpoint } \\
\text { Theory) } \\
\text { (Harding, } \\
\text { Wood, 2014) }\end{array}$ & 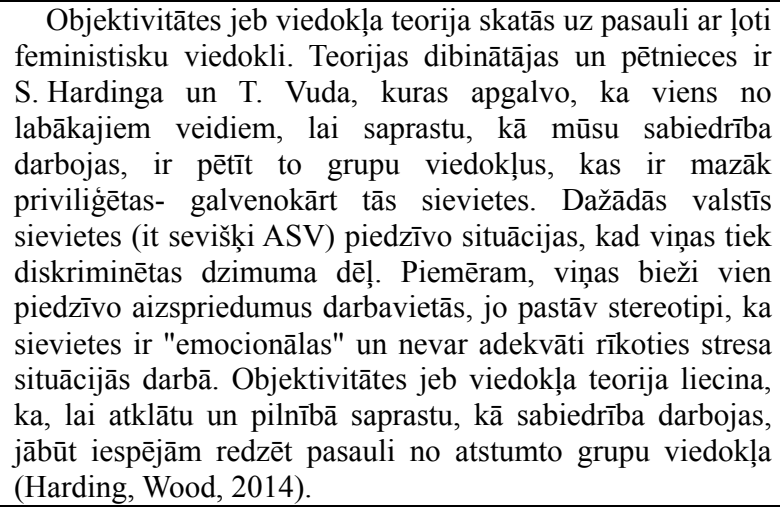 \\
\hline
\end{tabular}

Avots: autores apkopojums

Komunicēšanas prasmes ir saistītas arī ar katra cilvēka individuālo karjeru, un ir būtisks ikviena speciālista sociālās kompetences rādīiājs, ko augstu vērtē visa sabiedrība, jo bieži vien nespēja būt par labu saskarsmes partneri ir šķērslis indivīda karjeras izaugsmei. Balstoties iepriekšējos pētîjumos un izmantojot dzimumu komunikāciju teoriju atziņas (skat. 3.tab.), autore ir izstrādājusi kopsavilkumu par dzimumatbilstības principa dimensijām, kas ietver gan likumos noteiktos normatīvus, gan sabiedrībā esošos stereotipus par sieviešu un vīriešu atšķirībām, gan priekšlikumus dzimumu līdztiesības problēmu risinājumam (skat. 1. att.).

Priekšlikumos ir akcentēta nepieciešamība sekmēt likumā noteikto dzimumu līdztiesību ievērošanu un komunikāciju teoriju izmantošanu (dzimumu komunikāciju stili; interaktīvā universiālisma teorija; klusējošo grupu teorijas; sabiedrības androcentrisma ietekme uz profesijas izvēli; objektivitātes jeb viedokḷa teorija), stereotipu laušana un sieviešu pašapziņas celšana. 


\begin{tabular}{|c|c|}
\hline $\begin{array}{c}\text { Likumiskie normatīvi/ likumā noteiktā } \\
\text { līdztiesība }\end{array}$ & Sabiedrībā eksistējošie stereotipi \\
\hline $\begin{array}{l}\text { - sieviešu un vīriešu vienlīdzība, } \\
\text { - ekonomiskā neatkarība; } \\
\text { - vienlīdzīgs atalgojums par vienādu darbu; } \\
\text { - līdztiesība lēmumu pieņemšanā; } \\
\text { - cieņa; } \\
\text { - ar dzimumu saistības vardarbības } \\
\text { izbeigšana; } \\
\text { - dzimumu līdztiesības veicināšana ārpus } \\
\text { ES. }\end{array}$ & $\begin{array}{l}\text { - vēsturiski pieñemto sieviešu un } \\
\text { vīriešu profesijas; } \\
\text { - } \quad \text { stereotipi par viena vai otru } \\
\text { dzimuma lomu, uzvedību, } \\
\text { izskatu, prāta spējām. }\end{array}$ \\
\hline Realitāte & Problēmas \\
\hline $\begin{array}{l}\text { Dzimumu līdztiesības indekss (nodarbinātība, } \\
\text { ienākumi, zināšanas, laiks, vara, veselība). } \\
\text { Vidējais dzimumu līdztiesības indekss: } \\
\text { - ES - } 54 \\
\text { - Latvija - 44,4 } \\
\text { - Igaunija - 50 } \\
\text { - Lietuva - 43,6 }\end{array}$ & $\begin{array}{ll}\text { - } & \text { profesionālā krīze; } \\
\text { - } & \text { bezdarbs; } \\
\text { - } & \text { pedagogu dzimumu } \\
& \text { disproporcija; } \\
\text { - } & \text { ierobežotas iespējas sievietēm } \\
& \text { ieņemt dažādus amatus; } \\
\text { - } & \text { ierobežotas iespējas sievietēm } \\
& \text { ieņemt amatu vecuma dēḷ; } \\
\text { - } \quad \text { ierobežotas iespējas sievietēm } & \text { ieñemt amatu bērnu dēḷ. }\end{array}$ \\
\hline \multicolumn{2}{|c|}{$\begin{array}{l}\text { Darbība } \\
\text { priekšlikumi, kā risināt dzimumu līdztiesības problēmas }\end{array}$} \\
\hline \multicolumn{2}{|c|}{$\begin{array}{l}\text { - } \quad \text { Sekmēt likumā noteikto dzimumu līdztiesību. } \\
\text { Komunikāciju teorijas izmantošana: } \\
\text { - dzimumu komunikāciju stili; } \\
\text { - interaktīvā universiālisma teorija; } \\
\text { - klusējošo grupu teorijas; } \\
\text { - sabiedrības androcentrisma ietekme uz profesijas izvēli; } \\
\text { - objektivitātes jeb viedokļa teorija. } \\
\text { - } \quad \text { Stereotipu laušana. } \\
\text { - } \quad \text { Sieviešu pašapziņas celšana. }\end{array}$} \\
\hline \\
\hline
\end{tabular}

\section{1. att. Dzimumatbilstības principa dimensijas}

Avots: autores konstrukcija

Dzimumatbilstības princips karjeras konsultēšanā sievietēm izsaka sakarību veidošanos starp sieviešu karjeru ietekmējošiem faktoriem, profesionālo krīzi izraisošām situācijām, dzimumatbilstības principa dimensijām 
un profesionālās krīzes noteikšanas kritērijiem. Dzimumatbilstības principa ievērošana karjeras konsultēšanā sekmē karjeras attīstību profesionālā krīzē nonākušām sievietēm. Autore ir apkopojusi kritērijus, kas izriet no dzimumatbilstības principa dimensijām (skat.2. att.).

\begin{tabular}{|c|c|}
\hline Nr. & Kritēriji \\
\hline 1 & “Stikla griesti” sieviešu karjerā (Ķ̄ikule, 2006) \\
\hline 2 & $\begin{array}{l}\text { Stereotipi par sieviešu un vīriešu profesijām (Strategy for equality between } \\
\text { women and men } 2010-2015,2010 \text { ) }\end{array}$ \\
\hline 3 & $\begin{array}{l}\text { Vienlīdzīgs atalgojums par vienādu darbu neatkarīgi no dzimuma - gan vīriešiem, gan } \\
\text { sievietēm stratēǵija (Strategy for equality between women and men 2010-2015, 2010) }\end{array}$ \\
\hline 4 & Sievietēm atšķiras komunikācija komandā (pēc D. Tanenas (Tannen)) \\
\hline 5 & Sievietes sarunas gaitā viegli maina spēles noteikumus (pēc D. Tanenas) \\
\hline 6 & Sievietēm ir svarīga kooperēšanās un pati sarunas gaita (pēc D. Tanenas) \\
\hline 7 & $\begin{array}{l}\text { Sievietes izmanto sarunu, lai izrādītu interesi par citiem cilvēkiem un vinuu } \\
\text { vajadzībām, lai sadarbotos (pēc D. Tanenas) }\end{array}$ \\
\hline 8 & Sievietes pasaules redzējums balstās rūpēs un atbildībā (pēc D. Tanenas) \\
\hline 9 & $\begin{array}{l}\text { Sieviešu - vīriešu komunikāciju raksturo atšķirīgas saskarsmes normas un atšķirīgi } \\
\text { valodas lietošanas principi, un šīs atšķirības var traucēt sapratnei (pēc D. Tanenas) }\end{array}$ \\
\hline 10 & $\begin{array}{l}\text { Sarunā sievietēm raksturīgas priecīgākas balss intonācijas, apstiprinājumu } \\
\text { meklējoši jautājumi (vai ne? ja?), pastiprinātāji (tāds, daudz), īpaši pieklājīgas } \\
\text { teikuma konstrukcijas (vai jūs, lūdzu, neaizvērtu durvis) (pēc D. Tanenas) }\end{array}$ \\
\hline 11 & Sievietes sarunās spēj ilgstoši palikt vienas tēmas robežās (pēc D. Tanenas) \\
\hline 12 & $\begin{array}{l}\text { Tās sievietes, kuras ir klusas, tiek izstumtas no komunikācijas darbavietā, un karjeras } \\
\text { izaugsmes iespējas kolektīvā ir ierobežotas (pēc K. Krāmeres (Kramarae)) }\end{array}$ \\
\hline 13 & $\begin{array}{l}\text { Tās sievietes, kurām ir ǵimene un bērni, ir ierobežotas karjeras izvēlē } \\
\text { (pēc K. Krāmeres (Kramarae)) }\end{array}$ \\
\hline 14 & $\begin{array}{l}\text { Sievietes ir "emocionālas", un nevar adekvāti rīkoties stresa situācijās darbā (pēc } \\
\text { S. Benhabibas (Benhabib)) }\end{array}$ \\
\hline
\end{tabular}

\section{2. att. Kritēriji dzimumatbilstības principa ievērošanas ietekmes noteikšanai uz sieviešu karjeru}

Avots: autores apkopojums

Pirmie trīs kritēriji ņemti no profesionālās ierobežotības teorijas. Stikla griesti sieviešu karjerā nozīmē vertikālo darba tirgus segregāciju, kas apzīmē tendenci sievietēm un vīriešiem ieņemt atšķirīgus amatus vienā un tajā pašā profesiju grupā, kā arī tie ietver barjeras karjeras vertikālai izaugsmei. Kritēriji no 4. līdz 11. ir no D. Tanenas (Tannen, 1990/2007; Tannen, 1992a; Tannen 1992b) dzimumu komunikāciju teorijas. Kritēriji 12. un 13. n̦emti no K. Krāmeres klusējošo grupu teorijas (Kramarae, 1996a; 1996b; Ardener, 
Ardener, 2005). 14. kritērijs ir no S. Benhabibas intereaktīvās universālisma teorijas (Benhabib, 1992).

Šie kritēriji tiks izmantoti turpmākā pētījumā par dzimumatbilstības principa ietekmi uz sieviešu karjeru.

Promocijas darba trešajā nodaḷā Veidojošais eksperiments sieviešu profesionālās krīzes pārvarēěanai ir izstrādāta un ekspertēta sieviešu karjeras konsultēšanas metodika profesionālās krīzes situācijās un izstrādāts un zinātniski pamatots profesionālās krīzes pārvarēšanas modelis, aprakstīti veiktie karjeras mainas empīriskie pētījumi sievietēm Latvijā un Lietuvā un veidojošais eksperiments; veikta sieviešu karjeru ietekmējošo faktoru un karjeras attīstību veicinošo prasmju analīze. Trešo nodal̦u veido trīs apakšnodaḷas.

\section{1. apakšnodaḷā Pētỉjuma organizācija un bāzes raksturojums.} Pētījumu autore sāka veikt, izmantojot sociālos tīklus - kā draugiem.lv, facebook.lv, twitter.com, gan uzaicinot sievietes pildīt aptaujas anketas Nodarbinātības valsts aǵentūras Jelgavas, Bauskas, Dobeles reǵionālajās filiālēs, Valsts Policijas Zemgales reǵiona pārvaldē, kā arī tieši uzrunājot un izsūtot aptaujas anketas ar e-pasta vēstuḷu palīdzību gan Latvijā, gan Lietuvā dzīvojošām sievietēm. Respondenti izvēlēti nejauši. Izlase ir nevarbūtīgā, stihiski veidojusies. Katrā pētījumā izmantots mērkstiecības, pieejamības princips. Aptaujā piedalījās - 1087 sievietes, 48 - karjeras konsultanti, 4 - eksperti, 18 sievietes veidojošā eksperimentā.

Pētījumus shēma attēlota 3.attēlā. 

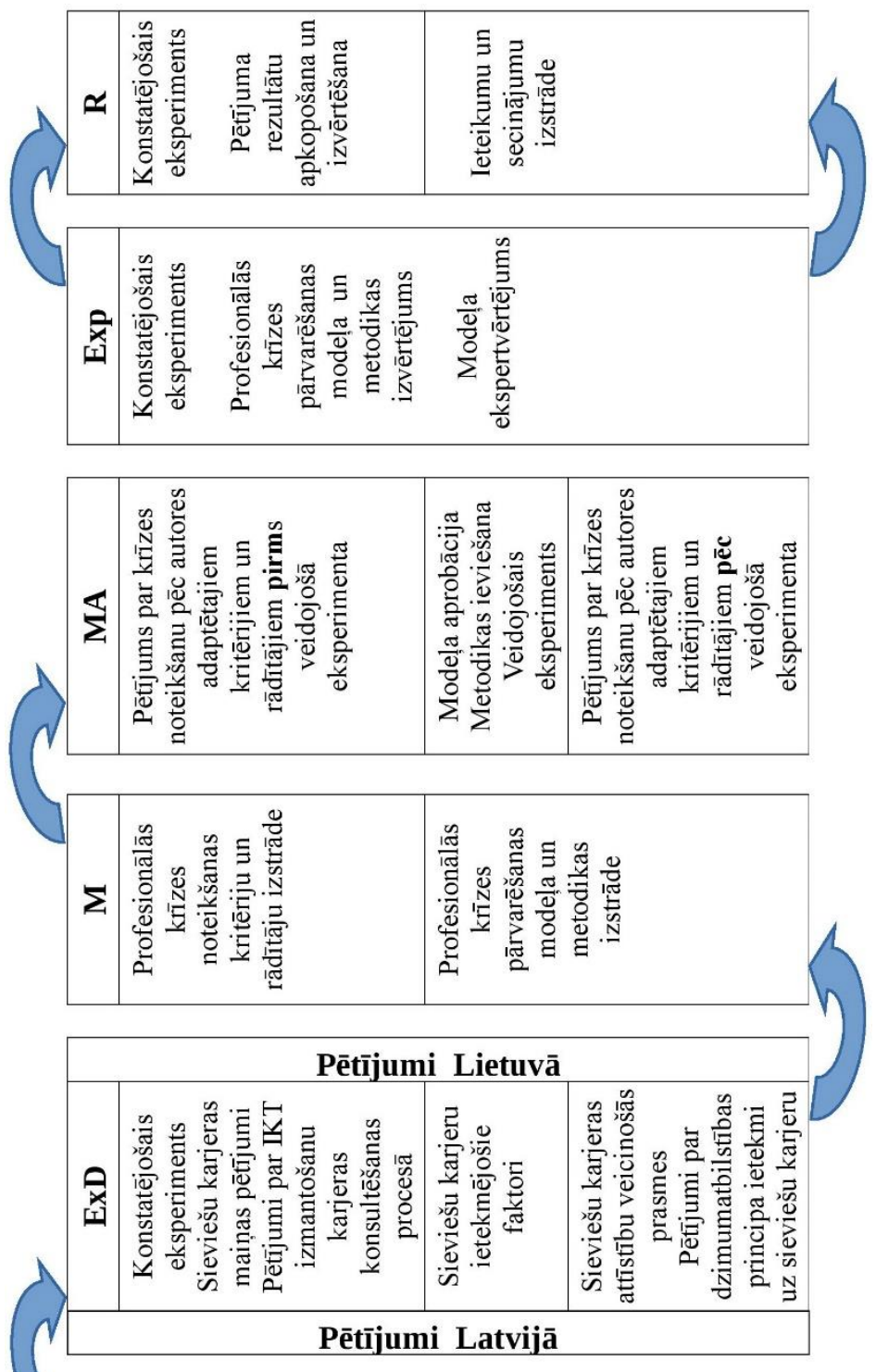

\begin{tabular}{|c|c|c|c|}
\hline$\infty$ & 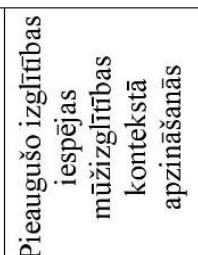 & 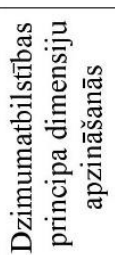 & 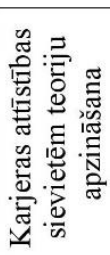 \\
\hline
\end{tabular}




\section{2. apakšnodạ̦ā Profesionālās krīzes pārvarēšanas modeḷa un}

metodikas izstrāde. Šajā apakšnodaḷā ir 8 apakšnodalas.

\subsection{1. apakšnodaḷā Sieviešu karjeras mainas pētījumu rezultāti} apkopoti, aprēķināti aptaujā piedalījušos sieviešu statistiskie rādītāji un analizēti sieviešu aptaujas rezultāti.

Aptauja tika veikta no 2015. gada 1.jūnija līdz 2015. gada 18.augustam, izsūtot 2000 anketas sievietēm pa e-pastu Latvijā un Lietuvā, kā arī aptaujājot klātienē. Atpakal̦ saņemtas aizpildītas 1087 derīgas anketas, no tām 909 no sievietēm Latvijā, un 178 sievietēm Lietuvā. Sieviešu anketēšana notika, izsūtot tās pa e-pastu, kā arī sociālajā tīklā www.draugiem.lv, twitter.com, facebook.com. Aptaujas anketas tika izstrādātas, izmantojot www.visidati.lv piedāvātās anketu matricas, lai vieglāk un ērtāk būtu respondentiem tās aizpildīt. Rezultāti apstrādāti, izmantojot grupēšanas metodi, aprakstošo statistiku, izmantojot MS Excel, SPSS (Paura, Arhipova, 2002).

Pētījuma sākumā respondentēm tika jautāts, cik lielā mērā viñas būtu gatavas mainīt darbu vai nodarbošanos un novērtēt ballēs intervālā no „1" līdz ,5”, kur „1" nozīmē, ka „pašlaik” - nav gatavi mainīt darbu un ,5” nozīme, ka darba vai nodarbošanās maiņa šobrīd ir maksimāli nepieciešama. $42 \%$ respondentes atbildēja, ka pašlaik nav gatavi mainīt darbu, bet $10 \%$ ir nolēmuši mainīt darbu.

Tika noskaidrots vai respondentes savu pašreizējo situāciju raksturotu kā krīzi (bīstams, sarežǵīts, smags stāvoklis). Jā atbildējuši $29 \%$, nē - 72 \% respondentu.

Var secināt, ka 29 \% sieviešu tomēr jūtas krīzes situācijā un vin̄ām ir nepieciešama palīdzība profesionālās krīzes pārvarēšanā. Tā tiek piedāvāta ar profesionālās krīzes pārvarēšanas model̦a palīdzību (skat. 4. att.).

\subsection{2. apakšnodaḷā Sieviešu karjeru ietekmējošo faktoru pētījumi.}

Izpètīti Sieviešu karjeru ietekmējušie profesijas izvēles faktori, noskaidroti un izanalizēti sieviešu karjeras ietekmējošie faktori respondentu skatījumā.

Lai noskaidrotu, kādi ir būtiskākie profesijas izvēles faktori sievietēm pēc respondentu domām, lūgts saranžèt pēc nozīmības, cik dotie faktori ietekmē sieviešu veiksmīgu karjeras attīstību. Atbilžu varianti bija pieci, sākot no "1" - neietekmē nemaz, „5" - lıti ietekmē. Analīzei ir izvēlēts atbilžu variants "loti ietekmē". Nepieciešams noskaidrot respondentu atbilžu skaita vienmērīgu sadalījumu un atbilstību teorētiskajam novērojumu skaita sadalījumam (skat 4. tab.). 
4. tabula

Sieviešu veiksmīgu karjeru ietekmējošo faktoru ranžējums

Dati iegūti 01.06.2015.-18.08.2015. anonīmi aptaujājot sievietes, n=1087

\begin{tabular}{|c|c|c|c|c|}
\hline Nr. & Faktori & $\begin{array}{c}\text { Novērotais } \\
\text { atbilžu } \\
\text { biežums }\end{array}$ & $\begin{array}{c}\text { Teorētiskais } \\
\text { atbilžu } \\
\text { biežums }\end{array}$ & $\begin{array}{c}\text { Starpība starp } \\
\text { novēroto un } \\
\text { teorētisko } \\
\text { biežumu }\end{array}$ \\
\hline 1. & Vecums & 297 & 268.3 & 28.7 \\
\hline 2. & Dzimums & 94 & 268.3 & -174.3 \\
\hline 3. & $\begin{array}{l}\text { Ģimenes apstāklli } \\
\text { (precējusies. } \\
\text { neprecējusies) }\end{array}$ & 111 & 268.3 & -157.3 \\
\hline 4. & $\begin{array}{l}\text { Gimenes pieredze } \\
\text { (vecāku profesijas } \\
\text { pieredze) }\end{array}$ & 82 & 268.3 & -186.3 \\
\hline 5. & Bērni (ir. nav. skaits) & 215 & 268.3 & -53.3 \\
\hline 6. & Izglītības līmenis & 558 & 268.3 & 289.7 \\
\hline 7. & Dzīves vieta & 259 & 268.3 & -9.3 \\
\hline 8. & Finansiālais stāvoklis & 198 & 268.3 & -70.3 \\
\hline 9. & $\begin{array}{l}\text { Brīvo darba vietu } \\
\text { skaits dzīves vietā }\end{array}$ & 443 & 268.3 & 174.7 \\
\hline 10. & Fiziskie dotumi & 152 & 268.3 & -116.3 \\
\hline 11. & Dzīves veids & 161 & 268.3 & -107.3 \\
\hline 12. & Vadības attieksme & 438 & 268.3 & 169.7 \\
\hline 13. & $\begin{array}{l}\text { Psiholoğiskais } \\
\text { klimats }\end{array}$ & 439 & 268.3 & 170.7 \\
\hline 14. & $\begin{array}{l}\text { Darba vietas attālums } \\
\text { no mājām }\end{array}$ & 236 & 268.3 & -32.3 \\
\hline 15. & Partnera atbalsts & 341 & 268.3 & 72.7 \\
\hline \multicolumn{5}{|c|}{$\chi^{2}$ testa rezultāti } \\
\hline \multicolumn{2}{|c|}{ Rādītāji } & \multicolumn{3}{|c|}{ Atbildes } \\
\hline \multicolumn{2}{|c|}{$\chi^{2}$ faktiskā vērtība } & \multicolumn{3}{|c|}{1126.770} \\
\hline \multicolumn{2}{|c|}{ Brīvības pakāpju skaits } & \multicolumn{3}{|c|}{14} \\
\hline \multicolumn{2}{|c|}{ p-vērtība } & \multicolumn{3}{|c|}{0.000} \\
\hline
\end{tabular}

Secinājums. Tā kā p-vērtība $=0.000<0.05$, tad ar varbūtību $95 \%$ var secināt, ka respondentu atbilžu skaits ir būtiski atšķirīgs un tas nesadalās vienmērīgi (Paura, Arhipova, 2002). Izmantojot $\chi^{2}$ testa starpības, var novērot statistiski nozīmīgu atbildes pārsvaru 6.faktoram Izglìtības lìmenis. Tas nozīmē, ka visvairāk no aptaujātajām sievietēm par visbūtiskāko faktoru min izglīî̄bas līmeni. 2.vietā brīvo darba vietu skaits dzīves vietā, 3.vietā - psiholoǵisko klimatu, 4.vietā - vadības attieksmi, 5.vietā - partnera atbalstu. 
Profesiju daudzveidība ir lıti plaša, lai varētu izvēlēties sev piemērotu un vēlamu profesiju, vispirms ir jāizpēta sevi, kādas personīgās īpašības piemīt un kādas ir jāattīsta, un jāizpēta vēlamās profesijas apraksts, un jānoskaidro vai šī profesija ir atbilstoša vēlmēm. Tādēḷ autore aptaujā iekḷāva jautājumu par personīgajām īpašībām. Respondentiem jautāts - norādiet, kuras no dotajām personīgajām īpašībām ietekmē sieviešu karjeru veiksmīgu attīstību. Atbilžu varianti bija pieci, sākot no "1" - neietekmē nemaz, ,5" - loti ietekmē. Analīzei ir izvēlēts atbilžu variants "loti ietekmē". Nepieciešams noskaidrot respondentu atbilžu skaita vienmērīgu sadalījumu un atbilstību teorētiskajam novērojumu skaita sadalījumam (skat. 5. tab.).

Personīgo īpašību ietekmes nozīmīguma ranžējums

5. tabula

Dati iegūti 01.06.2015.-18.08.2015. anonīmi aptaujājot sievietes, n=1087

\begin{tabular}{|r|l|c|c|c|}
\hline Nr. & \multicolumn{1}{|c|}{ İpašības } & $\begin{array}{c}\text { Novērotais } \\
\text { atbilžu } \\
\text { biežums }\end{array}$ & $\begin{array}{c}\text { Teorētiska } \\
\text { is atbilžu } \\
\text { biežums }\end{array}$ & $\begin{array}{c}\text { Starpība starp } \\
\text { novēroto un } \\
\text { teorētisko biežumu }\end{array}$ \\
\hline 1 & Vēlme palīdzēt citiem & 131 & 407.7 & -276.7 \\
\hline 2 & Paciētība & 376 & 407.7 & -31.7 \\
\hline $\mathbf{3}$ & Uzṇēmība & $\mathbf{7 2 6}$ & 407.7 & $\mathbf{3 1 8 . 3}$ \\
\hline 4 & Jūtīgums & 153 & 407.7 & -254.7 \\
\hline $\mathbf{5}$ & Neatlaidība & $\mathbf{6 7 7}$ & $\mathbf{4 0 7 . 7}$ & $\mathbf{2 6 9 . 3}$ \\
\hline $\mathbf{6}$ & Mērķtiecība & $\mathbf{7 2 8}$ & $\mathbf{4 0 7 . 7}$ & $\mathbf{3 2 0 . 3}$ \\
\hline 7 & $\begin{array}{l}\text { Prasme glabāt } \\
\text { noslēpumus }\end{array}$ & 305 & 407.7 & -102.7 \\
\hline $\mathbf{8}$ & $\begin{array}{l}\text { Prasme tikt galā ar } \\
\text { stresu }\end{array}$ & $\mathbf{6 2 1}$ & $\mathbf{4 0 7 . 7}$ & $\mathbf{2 1 3 . 3}$ \\
\hline 9 & Zinātkāre & 337 & 407.7 & -70.7 \\
\hline 10 & Uzticamība & 507 & 407.7 & 99.3 \\
\hline 11 & Sirsnīgums & 130 & 407.7 & -277.7 \\
\hline 12 & Prasmīgums & 435 & 407.7 & 27.3 \\
\hline 13 & Empātija & 175 & 407.7 & -232.7 \\
\hline 14 & Runīgums & 181 & 407.7 & -226.7 \\
\hline 15 & Spēja sevi kontrolēt & 512 & 407.7 & 104.3 \\
\hline 16 & Apñēmīgums & 570 & 407.7 & 162.3 \\
\hline 17 & Radošums & 415 & 407.7 & 7.3 \\
\hline 18 & Pašpārliecinātība & 566 & 407.7 & 158.3 \\
\hline $\mathbf{1 9}$ & Loğiska domāšana & $\mathbf{6 1 9}$ & $\mathbf{4 0 7 . 7}$ & $\mathbf{2 1 1 . 3}$ \\
\hline 20 & Centīgums & 435 & 407.7 & 27.3 \\
\hline & & & & \\
\hline
\end{tabular}


5. tabulas turpinājums

\begin{tabular}{|c|c|c|c|c|}
\hline Nr. & Īpašības & $\begin{array}{c}\text { Novērotais } \\
\text { atbilžu } \\
\text { biežums }\end{array}$ & $\begin{array}{c}\text { Teorētiska } \\
\text { is atbilžu } \\
\text { biežums }\end{array}$ & $\begin{array}{c}\text { Starpība starp } \\
\text { novēroto un } \\
\text { teorētisko biežumu }\end{array}$ \\
\hline 21 & Lojalitāte & 394 & 407.7 & -13.7 \\
\hline 22 & Pienākuma apziṇa & 533 & 407.7 & 125.3 \\
\hline 23 & Drosmīgums & 404 & 407.7 & -3.7 \\
\hline 24 & Taktiskums & 375 & 407.7 & -32.7 \\
\hline 25 & Iecietīga & 209 & 407.7 & -198.7 \\
\hline 26 & Rūpīgums & 335 & 407.7 & -72.7 \\
\hline 27 & Godīgums & 408 & 407.7 & .3 \\
\hline 28 & Pieklājīgums & 323 & 407.7 & -84.7 \\
\hline 29 & Humora izjūta & 195 & 407.7 & -212.7 \\
\hline 30 & $\begin{array}{l}\text { Labas novērošanas } \\
\text { spējas }\end{array}$ & 352 & 407.7 & -55.7 \\
\hline 31 & Kārtīga un tīrīga & 277 & 407.7 & -130.7 \\
\hline 32 & Neatlaidīgums & 528 & 407.7 & 120.3 \\
\hline 33 & Disciplinētība & 522 & 407.7 & 114.3 \\
\hline \multicolumn{5}{|c|}{$\chi^{2}$ testa rezultāti } \\
\hline & Rādītāji & \multicolumn{3}{|c|}{ Atbildes } \\
\hline & $\chi^{2}$ faktiskā vērtība & \multicolumn{3}{|r|}{2312.445} \\
\hline & Brīvības pakāpju skaits & \multicolumn{3}{|r|}{32} \\
\hline & p-vērtība & & & 0.000 \\
\hline
\end{tabular}

Secinājums. Tā kā p-vērtība $=0.000<0.05$, tad ar varbūtību $95 \%$ var secināt, ka respondentu atbilžu skaits ir būtiski atšķirīgs un tas nesadalās vienmērīgi. Izmantojot $\chi^{2}$ testa starpības, var novērot statistiski nozīmīgu atbildes pārsvaru 6.personības īpašībai Mērktiecība un 3. personības īpašībai Uznēmība. Tas nozīmē, ka visvairāk no aptaujātajām sievietēm, par visbūtiskākajām personības īpašībām min mērḳtiecību, 2.vietā uzṇēmību, 3.vietā - neatlaidību, 4.vietā - prasmi tikt galā ar stresu, 5.vietā - logisko domāšanu. Tātad arī personīgās īpašîbas ir nozīmīgs aspekts veiksmīgai karjeras attīstībai.

\subsection{3. apakšnodaḹā Pētījumi par sieviešu karjeras attīstību veicinošām} prasmēm izpētīti sieviešu karjeras attīstību veicinošās prasmes respondentu skatījumā. Respondentēm tika jautāts, kuras no dotajām prasmēm ietekmē sieviešu karjeru veiksmīgu attīstību. Atbilžu varianti bija pieci, sākot no "1" - neietekmē nemaz, „5" - ļoti ietekmē. Analīzei ir izvēlēts atbilžu variants "loti ietekmē”. Nepieciešams noskaidrot respondentu atbilžu skaita vienmērīgu sadalījumu un atbilstību teorētiskajam novērojumu skaita sadalījumam (skat. 6. tab.). 
6. tabula

Sieviešu karjeras veiksmīgu attīstību veicinošo nozīmīgāko prasmju ranžējums

Dati iegūti 01.06.2015.-18.08.2015. anonīmi aptaujājot sievietes, $n=1087$

\begin{tabular}{|c|c|c|c|c|}
\hline Nr. & Prasmes & $\begin{array}{c}\text { Novēro- } \\
\text { tais } \\
\text { atbilžu } \\
\text { biežums }\end{array}$ & $\begin{array}{l}\text { Teorētis- } \\
\text { kais } \\
\text { atbilžu } \\
\text { biežums }\end{array}$ & $\begin{array}{c}\text { Starpība } \\
\text { starp novē- } \\
\text { roto un teorē- } \\
\text { tisko biežumu }\end{array}$ \\
\hline 1 & Sadarboties ar citiem cilvēkiem & 631 & 536.7 & 94.3 \\
\hline 2 & Risināt problēmsituācijas & 644 & 536.7 & 107.3 \\
\hline 3 & Uzklausīit citus cilvēkus & 420 & 536.7 & -116.7 \\
\hline 4 & Pārliecināt par savu viedokli & 470 & 536.7 & -66.7 \\
\hline 5 & Lietot ķermeņa un žestu valodu & 150 & 536.7 & -386.7 \\
\hline 6 & Uzṇemties atbildību & 599 & 536.7 & 62.3 \\
\hline 7 & Precīzi izpildīt darba uzdevumu & 583 & 536.7 & 46.3 \\
\hline 8 & Organizēt savu darbu & 702 & 536.7 & 165.3 \\
\hline 9 & Atrast problēmu risinājumus & 635 & 536.7 & 98.3 \\
\hline 10 & Darboties mainīgās situācijās & 524 & 536.7 & -12.7 \\
\hline 11 & Patstāvīgi pieṇemt lēmumus & 646 & 536.7 & 109.3 \\
\hline 12 & Vadīit citus cilvēkus & 468 & 536.7 & -68.7 \\
\hline 13 & Mērḳtiecīgi veidot karjeru & 509 & 536.7 & -27.7 \\
\hline 14 & Lietot datoru darbam ar tekstu & 509 & 536.7 & -27.7 \\
\hline 15 & $\begin{array}{l}\text { Lietot datoru darbam ar skaitlisko } \\
\text { informāciju }\end{array}$ & 464 & 536.7 & $-72,7$ \\
\hline 16 & $\begin{array}{l}\text { Lietot datoru informācijas } \\
\text { meklēšanai }\end{array}$ & 540 & 536.7 & 3.3 \\
\hline 17 & Lietot datoru komunikācijai & 437 & 536.7 & -99.7 \\
\hline 18 & Svešvalodu zināšanas & 550 & 536.7 & 13.3 \\
\hline 19 & Prezentācijas prasmes & 553 & 536.7 & 16.3 \\
\hline 20 & Vadīšanas pamatprasmes & 565 & 536.7 & 28.3 \\
\hline 21 & Līderība & 520 & 536.7 & -16.7 \\
\hline 22 & Prasmes strādāt komandā & 689 & 536.7 & 152.3 \\
\hline \multicolumn{5}{|c|}{$\chi^{2}$ testa rezultāti } \\
\hline & Rādītāji & \multicolumn{3}{|c|}{ Atbildes } \\
\hline & $\chi^{2}$ faktiskā vērtība & \multicolumn{3}{|r|}{539.079} \\
\hline & Brīvības pakāpju skaits & \multicolumn{3}{|r|}{21} \\
\hline & p-vērtība & \multicolumn{3}{|r|}{0.000} \\
\hline
\end{tabular}




\section{Secinājums.}

Tā kā p-vērtība $=0.000<0.05$, tad ar varbūtību $95 \%$ var secināt, ka respondentu atbilžu skaits ir būtiski atšķirīgs un tas nesadalās vienmērīgi. Izmantojot $\chi^{2}$ testa starpības, var novērot statistiski nozīmīgu atbildes pārsvaru 8.prasmei Organizēt savu darbu un 22. prasmei Prasmes strādāt komandā. Tas nozīmēe, ka visvairāk no aptaujātajām sievietēm, par visbūtiskākajām prasmēm atzīmē - prasmi organizēt savu darbu, 2.vietā prasmes strādāt komandā, 3.vietā - patstāvīgi pieņemt lēmumus, 4.vietā - risināt problēmsituācijas, 5.vietā - sadarboties ar citiem cilvēkiem.

\subsection{4. apakšnodaḷa Pētījums par profesionālās krīzes noteikšanu pēe kritērijiem un rādītājiem.}

Karjeras maiņas pētījums, kurš tika veikts no 2015. gada 1. jūnija līdz 2015. gada 18. augustam, kurā piedalījās 1087 sievietes, pētījuma 3.sadaḷā "Profesionālās krīzes pētījumu anketa", tika iekḷauts jautājums, vai pašreizējo situāciju karjerā raksturotu kā profesionālo krīzi? Ja respondents uz jautājumu atbild "jā̄", tad seko jautājumi par profesionālās krīzes noteikšanas rādītājiem un kritērijiem. Ja atbilde ir "nē", tad respondentam ir jāatbild uz nākamās sadaļas jautājumu. Apkopojot respondentu atbildes, 29 \% (310) sieviešu atzina, ka jūtas krīzes situācijā.

Pētījums par profesionālās krīzes noteikšanu pēc kritērijiem un rādītājiem tika turpināti ar tām 310 (29 \%) sievietēm, kuras atzina, ka ir profesionālajā krīzes situācijā. Pamatojoties uz 2.2. nodaļā profesionālās krīzes situāciju teorētisko analīzi, autore ir adaptējusi profesionālās krīzes noteikšanas kritērijus un rādītājus pēc E.F. Zejera (Э.Ф Зеep) un Е.Е. Simaņuka (Э.Э. Симанюк), ar kuru palīdzību paredzēts veikt sievietes krīzes situācijas pašvērtējumu pirms viṇa sāk konsultācijas. Atkārtota krīzes noteikšana pēc šiem kritērijiem un rādītājiem tiek veikta pēc modelī paredzēto pasākumu izpildes. Analizējot iegūto aptaujas datu sadaļu "Profesionālās krīzes pētījumu anketa", autore apkopoja atbildes: 1 - pilnībā nepiekrītu; 2 - nepiekrītu; 3 - neitrāli; 4 - piekrītu; un 5 - pilnībā piekrītu. Analizējot datus, kopā tiek skaitīti apgalvojumi ,piekrītu” un 'pilnībā piekrītu", un attiecīgi "pilnībā nepiekrītu" un "nepiekrītu".

Apkopojot aptaujas datu sadą̧as "Profesionālās krīzes pētījumu anketas" respondentu atbildes, var secināt, ka izmantojot profesionālās krīzes noteikšanai izstrādātos kritērijus un rādītājus, un skaitot kopā apgalvojumus ,piekrītu” un 'piln̄īā piekrītu", 60 \% respondentu bija apmierināti ar profesionālo izglīîibu, $65 \%$ apmierināti ar profesionālo sagatavotību, taču liels skaits respondentu savā pašvērtējumā uzrādīja neapmierinātību: $57 \%$ bija neapmierināti ar iespējām realizēt sevi izveidojušajās profesionālajās situācijās; 46 \% bija neapmierināti ar savu sociāli profesionālo statusu, 48 \% juta psihofiziologiskās izmaiñas un veselības pasliktināšanos un $26 \%$ atzina profesionālo deformāciju, kas izsaka krīzes situācijas esamību.

Tā kā pietiekami liels skaits respondentu atzina neapmierinātību ar savu profesionālo darbību, kas apliecināja krīzes situācijas, tas norāda uz 
nepieciešamību pēc karjeras atbalsta, ko autore piedāvā, izmantojot krīzes pārvarēšanas modeli.

\subsection{5. apakšnodaḷa Pētījumi par dzimumatbilstības principa ietekmi uz} sieviešu karjeru apkopoti un analizēti divi pētījumi saistībà ar šo tēmu.

Pirmais pētījums par dzimumatbilstības principu sieviešu karjerā tika veikts no 2014. gada decembra līdz 2015. gada janvārim karjeras konsultantu vidū, lai gūtu priekšstatu par dzimumatbilstības principa ietekmi uz sieviešu karjeru. Aptaujā piedalījās 48 karjeras konsultanti. Pētījumā tika izmantoti kritēriji dzimumatbilstības principa ievērošanas ietekmes noteikšanai uz sieviešu karjeru, kas tika izstrādāti 2.3. nodaļā. Pēc pētījuma rezultātiem, var secināt, ka visvairāk no aptaujātajiem karjeras konsultantiem piekrituši šādiem apgalvojumiem:

- sievietes izmanto sarunu, lai izrādītu interesi par citiem cilvēkiem un viņu vajadzībām, lai sadarbotos - 85 \%;

- sievietēm ir svarīga kooperēšanās un pati sarunas gaita - $83 \%$;

- sievietēm atšķiras komunikācija komandā - 79 \%;

- pastāv stereotipi par sieviešu un vīriešu profesijām - $79 \%$;

- sievietes pasaules redzējums balstās rūpēs un atbildībā - $73 \%$.

Nepiekrīt šādiem apgalvojumiem:

- sievietes ir "emocionālas", un nevar adekvāti rīkoties stresa situācijās darbā - $81 \%$;

- pastāv "stikla griesti” sieviešu karjerā - $73 \%$;

- pastāv vienlīdzīgs atalgojums par vienādu darbu neatkarīgi no dzimuma - gan vīriešiem, gan sievietēm - $56 \%$.

Otrs pētījums par dzimumatbilstības principu sieviešu karjerā 2015 gadā tika veikts no 2015. gada 1 . jūnija līdz 2015. gada 18. augustam, kurā piedalījās 1087 sievietes un autore apkopoja atbildes.

Analizējot aptaujas datu sadalu "Anketa dzimumatbilstības principa ietekmes noteikšanai uz sieviešu karjeru" pētījuma rezultātus, redzam, ka $85 \%$ respondenti atzīst, ka pastāv stereotipi par sieviešu un vīrieši profesijām, 80 \% respondentu atzīmē, ka sievietēm atšķiras komunikācija komandā un $58 \%$ norāda, ka sieviešu un vīriešu komunikāciju raksturo atšķirīgas saskarsmes normas un atšķirīgi valodas lietošanas principi un š̄̄s atšķirības var traucēt sapratnei. $64 \%$ respondentu apstiprina, ka tās sievietes, kuras ir klusas, tiek izstumtas no komunikācijas darbavietā, un karjeras izaugsmes iespējas kolektīvā ir ierobežotas, un 53 \% norāda, ka tās sievietes, kurām ir gimene un bērni, ir ierobežotas karjeras izvēlē. Mazliet mazāk par pusi 49 \% norāda, ka stikla griesti tomēr pastāv.

Lai pētītu dzimumatbilstības principa ietekmi uz sieviešu karjeru, aptaujas datu sadaļā "Anketa dzimumatbilstîbas principa ietekmes noteikšanai uz sieviešu karjeru" tika iekḷauti jautājumi, kuri ietekmē karjeras attīstības problēmu risinājumu sievietēm un respondentu atbildes dotas 7. tabulā. 
Respondentu viedoklis par rīcības veidiem dzimumatbilstības principa ievērošanā karjeras atbalstam sievietēm (\%)

\begin{tabular}{|c|c|c|c|c|c|c|}
\hline \multirow{2}{*}{$\begin{array}{l}\text { Kā dzimumatbilstības } \\
\text { principa ievērošana } \\
\text { ietekmē karjeras } \\
\text { attīstības problēmu } \\
\text { risinājumu sievietēèm? }\end{array}$} & \multicolumn{5}{|c|}{ Respondentu vērtējumi } & \multirow[b]{2}{*}{$\begin{array}{c}\text { Kopā } \\
(\%)\end{array}$} \\
\hline & $\begin{array}{c}1 \\
\text { neietekmēemaz } \\
\text { nemaz }\end{array}$ & $\begin{array}{c}2 \\
\text { neietek- } \\
\text { mē }\end{array}$ & $\begin{array}{c}3 \\
\text { neitrāli }\end{array}$ & $\begin{array}{c}4 \\
\text { nedaudz } \\
\text { ietekmē }\end{array}$ & $\begin{array}{c}5 \\
\text { loti } \\
\text { ietekmēe }\end{array}$ & \\
\hline $\begin{array}{l}\text { Komunikāciju teorijas } \\
\text { izmantošana }\end{array}$ & 4 & 7 & 39 & 33 & 17 & 100 \\
\hline Stereotipu laušana & 2 & 5 & 36 & 36 & 21 & 100 \\
\hline $\begin{array}{l}\text { Sieviešu pašapziņas } \\
\text { celšana }\end{array}$ & 2 & 3 & 24 & 36 & 35 & 100 \\
\hline $\begin{array}{l}\text { Dzimumu līdztiesības } \\
\text { ievērošana }\end{array}$ & 2 & 4 & 28 & 31 & 35 & 100 \\
\hline
\end{tabular}

Autores izstrādātais un teorētiski pamatotais dzimumatbilstības princips, kas ir ieteicams karjeras konsultēšanā sievietēm krīzes situācijās, ietver sekojošas dimensijas: likumos noteiktā dzimumu līdztiesība, sabiedrībā eksistējošie stereotipi, dzimumu līdztiesības indekss, ieteikumi darbībai dzimumu līdztiesību problēmsituāciju risinājumam - sekmēt likumā noteikto dzimumu līdztiesību, izmantot komunikāciju teorijas sieviešu un vīriešu saziņā un konsultēšanā, lauzt stereotipus, celt sieviešu pašapziņu. Veicot pētījuma rezultātu analīzi, skaitot kopā atbildes „,nedaudz ietekmē” un ,, loti ietekmē”, var secināt, ka respondenti atzīst komunikāciju teoriju izmantošanu (50\%); stereotipu laušanu (57\%); sieviešu pašapziṇas celšanu $(71 \%)$ un dzimumu līdztiesības ievērošanu (66 \%) par nepieciešamu darbību karjeras atbalstam (skat. 6. tab.).

Izmantojot $\chi^{2}$ testa starpības, var novērot statistiski nozīmīgas atbildes Sieviešu pašapziņas celšana un Dzimumu līdztiesības ievērošana. Tātad respondenti uzskata, ka dzimumatbilstības principa ievērošana loti ietekmē sieviešu pašapziņas celšanu un dzimumu līdztiesības ievērošanu. Tātad dzimumatbilstības principa ievērošana būtiski ietekmē karjeras attīstības problēmu risinājumu sievietēm.

3.2.6. apakšnodaḷā Diskusija par karjeras maiņu sievietēm ir apkopotas dažāà zinātnieku atziṇas par sieviešu karjeras attīstību un maiņu.Pēdējos gados pasaulē, sevišķi Eiropā un arī Latvijā, mūžizglītība ir kḷuvis aktuāls jēdziens. Latvijā mūžizglìtīiba dažāâos aspektos ir pētīta daudz, bet tieši saistībā ar tās nozīmi un ietekmi sievietes karjerā profesionālās krīzes situācijās tā ir maz pētīta, to zināmā mērā apstiprina fakts, ka nav pieejamas publikācijas par praktiskajiem pētījumiem, kas veikti Latvijā. 
Viens no pētījumiem LLU, ko veica D. Bite, pētot nodarbinātības problēmas mazpilsētas, tā ietvaros pētīja Sieviešu profesionālo karjeru mazpilsētās, kurā noskaidroja, ka mazpilsētās ir cieša sociālās vides un infrastruktūras saistība ar nodarbinātības situāciju un līdz ar to mērķtiecīga karjeras virzība ir iespējama ierobežotā skaitā profesiju un darba vietu.

Amerikāņu zinātnieks, pedagogs D.R. Vetzels (Wetzel), veic pētījumus ASV par pieaugušo izglītību, mūžizglītību. Vinsš min, ka mūžizglìtība ir būtiska šodien visiem darbiniekiem, tiem, kas pašlaik strādā un tiem, kas meklē darbu, ka ir nepieciešams pastāvīgi atjaunot un paplašināt darba iemaņas.

Interesanti pētījumi, ko veica K. Kaprino (Caprino, 2015), kas ir pētniece un darba un dzīves trenere ASV, ir sieviešu profesionālās karjeras pētījums, kurā minēts, ka sievietes, kuras gadiem ilgi veido veiksmīgu karjeru, vidējos mūža gados jūt, ka viṇu profesionālā dzīve un identitāte vairs viņas neapmierina, t.i. nedarbojas, kā ieplānots. Pētījumā konstatēts, ka lielākā daļa sieviešu saskaras ar vismaz vienu no autores minētām slēpto darba un privātās dzīves krīzēm, tostarp arī hroniskām veselības problēmām, finanšu atkarību un sāpīgu es zaudējumu.

Par karjeras mainuu un dažādiem padomiem, kā to labāk izdarīt, rakstījuši vairāki autori: A. Krove (Crowe), M. Profita, M. Millere (Crowe, 2009; Profita, 2016; Miller, 2016). Amerikāṇu zinātniece E. Ostrova (Ostrow, 2012) ir dzīves un karjeras trenere, tas pašlaik ASV ir l̦oti populārs nodarbošanās veids, viņa praktizē un pēta sieviešu karjeru, tās mainuu. Iepazīstoties ar ārzemju un Latvijas zinātnieku pieredzi un publikācijām, autore secina, ka Latvijā ir aizsākta jauna tēma turpmākiem pētījumiem saistībā ar sieviešu karjeru, to mainu profesionālās krīzes situācijās, kā arī par mūžizglîtības nozīmi sieviešu karjeras attīstībā.

3.2.7. apakšnodaḷā Profesionālās krīzes pārvarēšanas modelis autore ir izstrādājusi, zinātniski pamatojusi profesionālās krīzes pārvarēšanas modeli sievietēm, sniedz detalizētu model̦a apraksta.Pedagoǵiskos model̦os tiek īstenota teorijas un praktiskās mācīšanās realizēšanas vienotība. Modelis pedagogijīā raksturo un ļauj prognozēt gaidāmos rezultātus no pedagoǵiskā procesa (Žogla, 2001). Tādēl ir svarīgi šādu modeli integrēt karjeras atbalsta procesā, ietverot gan karjeras izglīīibu, karjeras konsultēšanas procesu gan karjeras atbalsta un karjeras pētniecisko dą̧u, lai sasniegtu rezultātu.

Lai šos uzdevumus veiktu un lai sniegtu atbalstu sievietēm profesionālās krīzes situācijās, darba autore izstrādājusi - Profesionālās krīzes pārvarēšanas modeli sievietēm (skat. 4. att.).

Tās mērḳauditorija - sievietes, kuras vēlas vai ir spiestas mainīt nodarbošanos, atrodoties profesionālās krīzes situācijā.

Modeḷa mērḳis - apzināt situāciju klienta karjeras attīstībā, noteikt galvenos virzienus, cel̦us, kā uzsākt karjeras mainu, noteikt prasmes un vēlmes, novērtēt nākamās profesijas iespējamību, piedāvāt karjeras atbalsta konsultācijas un izglītojošo programmu, lai pārvarētu profesionālo krīzi. 


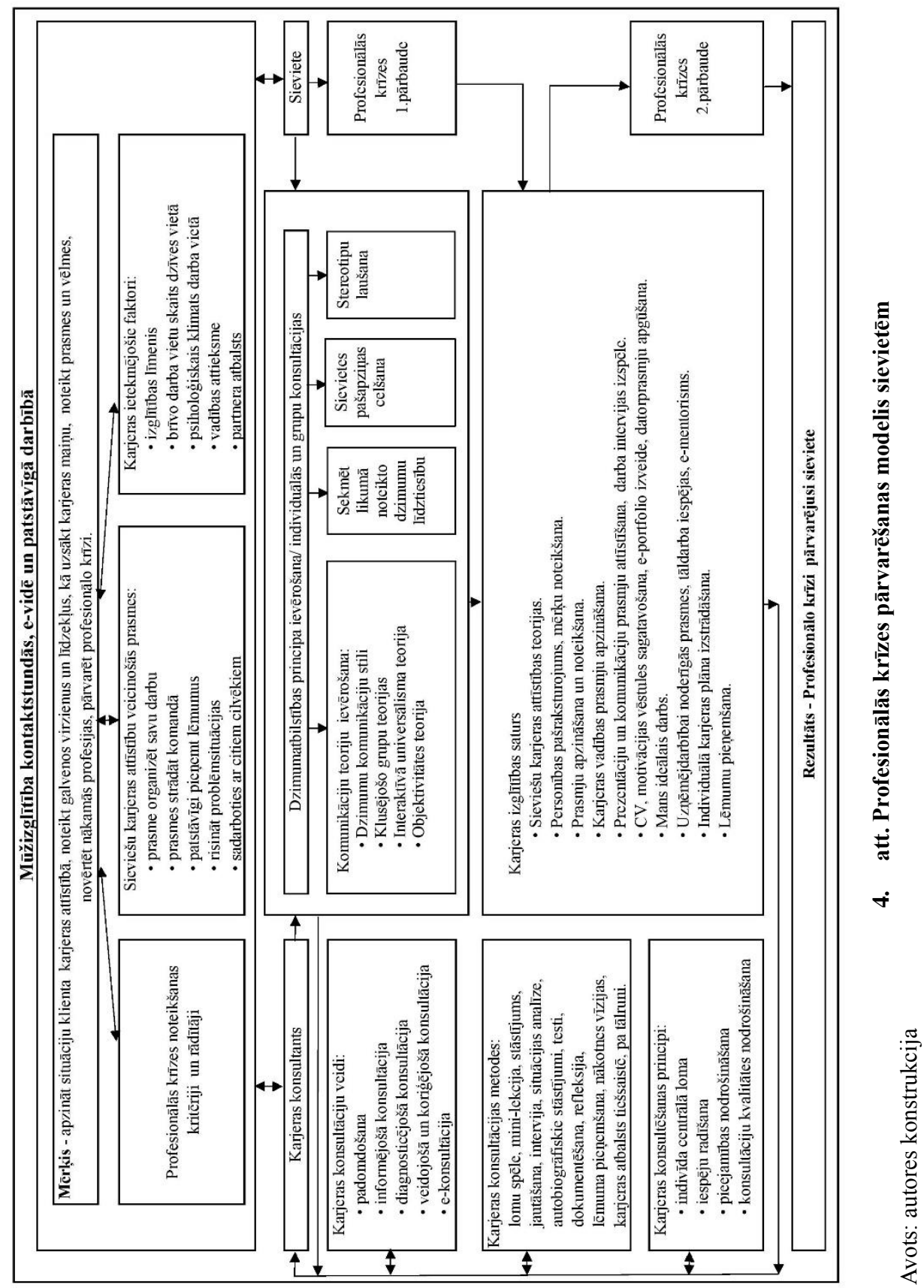


3.2.8. apakšnodaḷā Profesionālās krīzes pārvarēšanas metodikas izstrāde tiek teorētiski pamatota metodika un izstrādāts un sniegts nodarbību plānojums klienta attīstošai programmai karjeras mainai sievietēm profesionālās krīzes situācijās e-vidē, dalībnieču refleksijas piemēri izlases kārtībāa, e-portfolio izveides nozīmīgs, pašnodarbinātības pasākumi, tāldarba iespējas, e-mentorisma veidi un darbības jomas. Klienta attīstošā programma karjeras mainai sievietēm profesionālās krīzes situācijās, ir paredzēta, lai palīdzētu sievietēm, kad nepieciešams padoms un atbalsts krīzes situācijā, lai sniegtu nepieciešamo informāciju, veicinātu domāšanu, analizēt apkārtējo situāciju, celtu viņas pašpārliecinātību un veicinātu profesionālo veiksmi. Tās ietvaros paredzētas 10 individuālās nodarbības, kurās, strādājot ar klientu, ir plānots iepazīties ar klientu un tā problēmām, veikt dažādus uzdevumus, testus, kopā strādāt līdz nonāk līdz lēmumu pieņemšanai.

Programmā izmantojamās galvenās karjeras konsultēšanas metodes: lomu spēle, autobiogrāfisko stāstījumi, testu metode, dokumentēšana; situācijas analīzi; lēmuma pieñemšana; atgriezeniskā saite; nākotnes vīzijas; e-konsultēšana. Rezultātā pēc izglītības satura apguves autores piedāvātajā klienta attīstošajā programmā tiek veikta profesionālās krīzes noteikšanas atkārtota pārbaude.

Pielietojot šo modeli profesionālās krīzes situācijā nonākušu sieviešu karjeras atbalstam, gala rezultāts ir harmoniska, profesionālo krīzi pārvarējusi sieviete.

Nodarbību vispārīgs plānojums ir apkopots 8. tabulā, bet programma kopumā un katram tematam atsevišksi, formulēts apguves mērḳis un sasniedzamie rezultāti ir darba pielikumā.

8. tabula

Nodarbību plānojums klienta attīstošai programmai karjeras maiṇai sievietēm profesionālās krīzes situācijās e-vidē

\begin{tabular}{|c|l|l|c|}
\hline Nr. & \multicolumn{1}{|c|}{$\begin{array}{c}\text { Nodarbības } \\
\text { temats }\end{array}$} & \multicolumn{1}{c|}{ Temata apraksts } & $\begin{array}{c}\text { Laiks } \\
\text { min }\end{array}$ \\
\hline 1 & $\begin{array}{l}\text { Sievietēm } \\
\text { piemērojamas } \\
\text { karjeras attīstības } \\
\text { teorijas }\end{array}$ & $\begin{array}{l}\text { Ievadinformācija. Profesionālās krīzes noteikšanas } \\
\text { tests. Konsultants sniedz īsu priekšstatu, kas ko } \\
\text { saņems no šīm nodarbībām, kādi noteikumi jāpilda, } \\
\text { un cik ilgi būs nodarbības. Sievietēm piemērojamas } \\
\text { karjeras attīstības teorijas. }\end{array}$ & 45 \\
\hline 2 & $\begin{array}{l}\text { Klienta } \\
\text { pašraksturojums } \\
\text { un mērksu } \\
\text { noteikšana }\end{array}$ & $\begin{array}{l}\text { Diskusija par uzdevumu „Mans dzīves koks”. } \\
\text { Uzdevums un diskusija „Darba esamības/ neesamības } \\
\text { novērtējums”. Klienta pieredzes noteikšana. Klienta } \\
\text { pašraksturojums, tā īpašību noteikšana. Klienta interešu } \\
\text { noteikšana.Lekcija. Mērku noteikšanas nozīmīgums. } \\
\text { Klienta mazo un lielo mērksu noteikšana. Diskusija. }\end{array}$ & 45 \\
\hline 3 & $\begin{array}{l}\text { Prasmju } \\
\text { apzināšana un } \\
\text { noteikšana }\end{array}$ & $\begin{array}{l}\text { Latvijas sociālajām un ekonomiskajām vajadzībām } \\
\text { nepieciešamās vispārējās prasmes. Klienta prasmju } \\
\text { apzināšana un noteikšana. Klienta personīgo } \\
\text { prasmju apzināšana un noteikšana. Klienta īpašās } \\
\text { spējas noteikšana. Diskusija. }\end{array}$ & 45 \\
\hline
\end{tabular}


8. tabulas turpimājums

\begin{tabular}{|c|c|c|c|}
\hline Nr. & $\begin{array}{l}\text { Nodarbības } \\
\text { temats }\end{array}$ & Temata apraksts & $\begin{array}{c}\text { Laiks } \\
\text { min }\end{array}$ \\
\hline 4 & $\begin{array}{l}\text { Karjeras vadības } \\
\text { prasmju } \\
\text { apzināšana }\end{array}$ & $\begin{array}{l}\text { Karjeras vadības prasmes. } \\
\text { Pašapziņa. Karjeras iespēju pêtīšanas un radī̌sanas } \\
\text { prasmes. Karjeras plānošanas prasmes. Lēmuma } \\
\text { piennemšanas prasmes. Spēja tikt galā ar } \\
\text { nenoteiktību. } \\
\text { Klienta karjeras vadības prasmju apzināšana un } \\
\text { noteikšana. } \\
\text { Diskusija. }\end{array}$ & 45 \\
\hline 5 & $\begin{array}{l}\text { Prezentāciju un } \\
\text { komunikāciju } \\
\text { prasmju } \\
\text { apzināǎana. } \\
\text { Darba intervijas } \\
\text { plāns. }\end{array}$ & $\begin{array}{l}\text { Prezentācijas prasmes. } \\
\text { Prezentēšanas pamati, gatavošanās veidi, efektīvu } \\
\text { prezentāciju veidošana. } \\
\text { Komunikāciju prasmes. } \\
\text { Prasme runāt un prasme klausīties. } \\
\text { Kā sagatavoties darba intervijai? Darba intervijas } \\
\text { būtība, raksturojums. Intervijas jautājumu veidi. } \\
\text { Interviju veidi. Atbilžu sagatavošana, būtiskāko } \\
\text { jautājumu-atbilžu analīze. Diskusija. }\end{array}$ & 45 \\
\hline 6 & $\begin{array}{l}\text { CV, motivācijas } \\
\text { vēstules } \\
\text { sagatavošana, e- } \\
\text { portfolio izveide, } \\
\text { datorprasmju } \\
\text { apgūšana. }\end{array}$ & $\begin{array}{l}\text { Lekcija. CV un motivācijas vēstules sagatavošana. } \\
\text { CV un motivācijas vēstules paraugu izmantošana no } \\
\text { interneta resursiem. Europass CV veidnes } \\
\text { izmantošana (teksta apstrādes programmā } \\
\text { OpenOffice.org izmantošana, tiešaistē). } \\
\text { Kas ir portfolio? Tā nozīme, portfolio veidošanas } \\
\text { iespējas un veidi. }\end{array}$ & 45 \\
\hline 7 & $\begin{array}{l}\text { Mans ideālais } \\
\text { darbs. }\end{array}$ & $\begin{array}{l}\text { Lekcija. Iepazīsties ar darba stila aprakstiem. } \\
\text { Uzdevums - Mans ideālais darbs un sava personīgā } \\
\text { Puzzles veidošana atbilstoši ideālā darbinieka } \\
\text { Puzzlei. } \\
\text { Mājas darbs. Sagatavot amatu aprakstu savam } \\
\text { "Ideālajam darbam" izmantojot profesiju standartu. }\end{array}$ & 45 \\
\hline 8 & $\begin{array}{l}\text { Uzñēmējejarbībai } \\
\text { noderīgās } \\
\text { prasmes, } \\
\text { tāldarba iespējas, } \\
\text { e-mentorisms. }\end{array}$ & 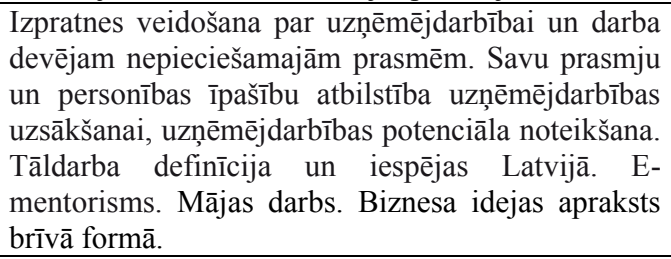 & 45 \\
\hline 9 & $\begin{array}{l}\text { Individuālā } \\
\text { karjeras plāna } \\
\text { izstrādāšana }\end{array}$ & $\begin{array}{l}\text { Izanalizēt situāciju klienta karjeras attīstībā, noteikt } \\
\text { galvenos virzienus, celus, kā uzsākt darba } \\
\text { meklēšanas procesu, kāà sagatavoties darbam, kurš } \\
\text { jau būs jaunā vidē un jaunā līmenī. }\end{array}$ & 45 \\
\hline 10 & $\begin{array}{l}\text { Lēmumu } \\
\text { pieņemšana. }\end{array}$ & $\begin{array}{l}\text { Lēmumu pieņemšana.Prioritāšu izvēle. } \\
\text { Karjeras izvēles situācijas simulācija. } \\
\text { Profesionālās krīzes noteikšanas tests. }\end{array}$ & 45 \\
\hline
\end{tabular}


Klienta attīstošā programma karjeras maiñai sievietēm profesionālās krīzes situācijās tika eksperimentāli aprobēta e-vidē Moodle programmā, veidojošajā eksperimentā piedaloties 18 brīvi izvēlētām sievietēm. Paralēli šīm nodarbībām autore organizēja eksperimenta dalībniecēm e-konsultācijas, kas tika veiktas gan ar e-pastu starpniecību, gan skype. Vidēji autore organizēja trīs konsultācijas katrai dalībniecei, veicot profesionālās krīzes mentora lomu. Programmas interneta adrese ir šeit - https://karjera.gnomio.com/.

\section{3. apakšnodal̄a Profesionālās krīzes pārvarēšanas modeḷa aprobācija} un ekspertvērtējums. Ietver divas apakšnodal̦as.

\subsection{1.apaškšnodaḷa Profesionālās krīzes pārvarēšanas modeḷa un metodikas ekspertvērtējums.}

Profesionālās krīzes pārvarēšanas modelim sievietēm tika veikta ekspertvērtēšana. Ar M. Kendela koeficienta W palīdzību nosaka korelāciju starp vairākiem main̄̄giem. Koeficientu nosaka, ja vienu pazīmi novērtēja dažādi eksperti (Paura, Arhipova, 2002). Profesionālās krīzes pārvarēšanas modeḷa ekspertvērtējumu rezultāti attēloti 9. tabulā, ekspertu viedokḷu vienprātības novērtējuma aprēķini redzami 1.,2. formulās.

9. tabula

\section{Profesionālās krīzes pārvarēšanas modẹ̦a sievietēm ekspertvērtējuma rezultāti}

Dati iegūti 2016. gada janvārī, ekspertiem ranžējot model̦a atbilstību.

\begin{tabular}{|c|c|c|c|c|c|c|c|c|c|}
\hline \multirow{3}{*}{ Vērtējuma kritēriji } & \multicolumn{4}{|c|}{ Eksperti } & \multirow{3}{*}{$\mathbf{L}_{\mathbf{i}}$} & \multirow{3}{*}{$\mathbf{d}_{\mathbf{i}}$} & \multirow{3}{*}{$d_{i}{ }^{2}$} & \multirow{3}{*}{$\begin{array}{c}\text { Rangs } \\
\text { R }\end{array}$} & \multirow{3}{*}{$\begin{array}{l}\text { Vieta } \\
\left(\mathbf{L}_{\mathbf{i}}\right. \\
\text { rangs })\end{array}$} \\
\hline & $\mathbf{A}$ & B & $\mathrm{C}$ & D & & & & & \\
\hline & \multicolumn{4}{|c|}{ Rangi $\mathbf{R}_{\mathbf{i}}$} & & & & & \\
\hline $\begin{array}{l}\text { Modelī piedāvātā } \\
\text { metodika ir atbilstoša un } \\
\text { pietiekama, lai veicinātu } \\
\text { profesionālās krīzes } \\
\text { pārvarěšanu }\end{array}$ & 2 & 2 & 1 & 3 & 8 & -6 & 36 & 2 & I \\
\hline $\begin{array}{l}\text { Izglītîbas saturs klienta } \\
\text { attīstošajā programmā } \\
\text { veicina sieviešu karjeras } \\
\text { maiṇu }\end{array}$ & 5 & 6 & 5 & 6 & 22 & 8 & 64 & 6 & III \\
\hline $\begin{array}{l}\text { Karjeras konsultēšanas } \\
\text { metodes ir pietiekamas } \\
\text { karjeras konsultēšanas } \\
\text { procesā }\end{array}$ & 6 & 4 & 4 & 5 & 19 & 5 & 25 & 4.5 & II \\
\hline $\begin{array}{l}\text { Autores piedāvātais } \\
\text { dzimumatbilstības princips } \\
\text { ietver visas nepieciešamās } \\
\text { dimensijas }\end{array}$ & 1 & 3 & 3 & 1 & 8 & -6 & 36 & 2 & I \\
\hline
\end{tabular}


9. tabulas turpinājums

\begin{tabular}{|c|c|c|c|c|c|c|c|c|c|}
\hline \multirow{3}{*}{ Vērtējuma kritēriji } & \multicolumn{4}{|c|}{ Eksperti } & \multirow{3}{*}{$\mathbf{L}_{\mathbf{i}}$} & \multirow{3}{*}{$\mathbf{d}_{\mathbf{i}}$} & \multirow{3}{*}{$\mathbf{d}_{\mathrm{i}}^{2}$} & \multirow{3}{*}{$\begin{array}{c}\text { Rangs } \\
\mathbf{R}\end{array}$} & \multirow{3}{*}{$\begin{array}{l}\text { Vieta } \\
\left(\mathbf{L}_{\mathbf{i}}\right. \\
\text { rangs })\end{array}$} \\
\hline & $\mathbf{A}$ & B & $\mathrm{C}$ & D & & & & & \\
\hline & \multicolumn{4}{|c|}{ Rangi $\mathbf{R}_{\mathbf{i}}$} & & & & & \\
\hline $\begin{array}{l}\text { Klienta attīstošā } \\
\text { programma karjeras } \\
\text { maiṇai sievietēm } \\
\text { profesionālās krīzes } \\
\text { situācijās mūžizglītībā ir } \\
\text { atbilstoša }\end{array}$ & 4 & 5 & 6 & 4 & 19 & 5 & 25 & 4.5 & II \\
\hline $\begin{array}{l}\text { Autores izveidotais } \\
\text { modelis veicina sieviešu } \\
\text { profesionālās krīzes } \\
\text { pārvarēšanu }\end{array}$ & 3 & 2 & 2 & 2 & 8 & $\overline{6}$ & 36 & 2 & I \\
\hline$n=6$ & & $\mathrm{~m}$ & & & $L_{i}=8$ & 0 & $\mathrm{~S}=22$ & & \\
\hline
\end{tabular}

Skaidrojumi 8.tabulai:

A, B, C, D - eksperti,

$\mathrm{L}_{\mathrm{i}}-$ rangu summa,

$\mathrm{d}_{\mathrm{i}}-$ rangu summa mīnuss rangu summas vidējā vērtīiba,

$\mathrm{d}_{\mathrm{i}}^{2}-\mathrm{d}_{\mathrm{i}} \mathrm{kvadrāta}$,

$\mathrm{R}$ - rangs.

Rangu summas vidējās vērtības $L_{v i d}$ aprēķins,

$$
L_{\text {vid }}=\frac{\sum L_{i}}{n}=\frac{84}{6}=14
$$

kur:

$\sum L_{i}-$ rangu summa,

$\mathrm{n}$ - novērtējamo faktoru skaits.

Konkordācijas koeficienta W aprēķins,

$$
W=\frac{12 \mathrm{~S}}{m^{2} n\left(n^{2}-1\right)}=\frac{12 \times 222}{16 \times 6(36-1)}=0.793
$$

kur:

W - konkordācijas koeficients,

$\mathrm{n}$ - novērtējamo faktoru skaits,

$\mathrm{m}$ - ekspertu skaits,

$\mathrm{S}$ - noviržu kvadrāta summa.

Autore izvirzīja hipotēzes:

$\mathrm{H}_{0}$ : nav sakarības starp dažādu ekspertu novērtējumiem $\mathrm{W}=0$,

$\mathrm{H}_{1}$ : ir sakarība starp dažādu ekspertu novērtējumiem $\mathrm{W} \neq 0$.

Hipotēzes pārbaudei (W būtiski atšķiras no nulle) izmanto formulu $\mathrm{x}^{2}=\mathrm{m}(\mathrm{n}-1) \mathrm{W}$ faktisko vērtību salīdzina ar $\mathrm{x}^{2}{ }_{\alpha, \mathrm{n}-1}$ kritisko vērtību (Arhipova, Paura, 2002).

$\mathrm{x}_{\mathrm{r}}^{2}=\mathrm{m}(\mathrm{n}-1) \mathrm{W}=4(6-1) 0.793=15.86$ faktisko vērtību salīdzina ar $\mathrm{x}_{\alpha, 5}^{2}=11.07$, kritisko vērtību. 
Secinājums. $\mathrm{x}_{\mathrm{r}}{ }_{\mathrm{r}}=\mathrm{m}(\mathrm{n}-1) \mathrm{W}>\mathrm{x}^{2}{ }_{\alpha, 5}=11.07$ noraida $\mathrm{H}_{0}$ un pieņem $\mathrm{H}_{1 \text {; }}$ pastāv sakarība starp dažādu ekspertu novērtējumiem, jo W būtiski atšķiras no nulles.

Eksperti samērā vienprātīgi $(\mathrm{W}=0.793, \mathrm{p}=0.007)$ novērtējuši modeli (skat. 1., 2. formulas), bet tomēr iezīmējās trīs grupas - 1.vieta - visaugstākais vērtējums apgalvojumam, ka modelī piedāvātā metodika ir atbilstoša un pietiekama, lai veicinātu profesionālās krīzes pārvarēšanu, autores piedāvātais dzimumatbilstības princips ietver visas nepieciešamās dimensijas, autores izveidotais modelis veicina sieviešu profesionālās krīzes pārvarēšanu, 2.vieta - otrs augstākais novērtējums apgalvojumam, ka karjeras konsultēšanas metodes ir pietiekamas karjeras konsultēšanas procesā, piedāvātā klientu attīstošāà programma karjeras maiņai sievietēm profesionālās krīzes situācijās mūžizglīîibā ir atbilstoša, 3.vietā - izglìtības saturs klienta attīstošajā programmā veicina sieviešu karjeras maiņu. Šāds profesionālās krīzes pārvarēšanas modelis būtu aktuāls un noderīgs praktiķiem karjeras konsultantiem, kuru varētu izmantot par pamatu, lai plānotu un sniegtu karjeras atbalstu sievietēm profesionālajās krīzes situācijās.

3.3.2. apakšnodaḷā Klienta attīstošās programmas pētījuma rezultāti karjeras mainai sievietēm profesionālās krīzes situācijās autore analizēe eksperimentā iegūtos datus, izmantojot adaptētos profesionālās krīzes noteikšanas kritērijus un rādītājus pēc E.F. Zejera (Э. Ф Зeep) un E.E. Simaņuka (Э.Э. Симанюк), ar kuru palīdzību veica sievietes krīzes situācijas pašvērtējumu pirms konsultācijas un izglītošanos, un atkārtoti pēc attīstošās programmas paredzēto nodarbību izpildes un konsultāciju saṇemšanas.

Izmantojot autores adaptētos kritērijus (skat. 2. tab.), tika veikts pētījums profesionālās krīzes noteikšanai pirms un pēc veidojošā eksperimenta, kura mērķis bija iegūt rezultātus, vai piedāvātā metodika profesionālās krīzes pārvarēšanai ir piemērota. Metodika rezultātu aprēḳināšanai: veidojošā eksperimenta dalībnieces atbildot uz jautājumu, novērtējot savu situāciju karjerā, izvēlas vienu no 5 dotajām atbildēm, kuras novērtētas arī ballēs (pilnībā nepiekrītu - 1, nepiekrītu - 2, neitrāli - 3, piekrītu - 4, pilnībā piekrītu - 5), un pēc programmas apgūšanas veic atkārtotu novērtēšanu. Datu analīzi veic pamatojoties uz šo rādītāju matemātiskām izmaiņām. Datu salīdzināšanai tika analizētas atbildes "pilnībā piekrītu", saskaitot 18 dalībnieču atbildes uz konkrēto jautājumu pirms un pēc veidojošā eksperimenta. Iegūtie rezultāti attēloti 5. attēlā.

Analizējot, veidojošā eksperimentā iegūtos datus, var secināt, ka no dotajiem 17 kritērijiem, pozitīvas izmaiņas ir novērojamas 9 kritērijos. Pozitīvo kritēriju izmaiņas - Man ir jauna profesionālo vērtību dominante +2 , Esmu apmierināta ar savām profesionālās izaugsmes iespējām +3 , Esmu apmierināta ar profesionālo izglîtību +1 , Es spēju realizēt profesionālos nodomus +1 , Manā dzīvē profesionālā karjera man ir nozīmīga +6 . Var secināt, ka sievietēm, ir cēlusies pašapziņa un pozitīva attieksme pret sevi. 
Es uzņemos arvien vairāk pienākumu, nekā spēšu paveikt, jo nemāku pateikt "nē"

Mana profesionālajā darbā man nav skaidrības par ko esmu atbildīga

Es jūtu profesijas psihofiziologiskās izmainas un veselības pasliktināšanos

Esmu neapmierināta ar savu sociāli profesionālo statusu

Esmu neapmierināta ar iespējām realizēt sevi izveidojušajās profesionālajās situācijās

Man ir jauna profesionālo vērtību dominante

Man ir grūtības profesionālās pašnoteikšanās īstenošanā

Man ir vajadzība pēc profesionālās pašnoteikšanās

Esmu apmierināta ar savām profesionālās izaugsmes iespējām

Esmu apmierināta ar savu profesionālo sagatavotību

Esmu apmierināta ar savu profesionālo izglìtību

Es spēju realizēt savus profesionālos nodomus

Manā dz̄ìē profesionālā karjera man ir nozīmīga

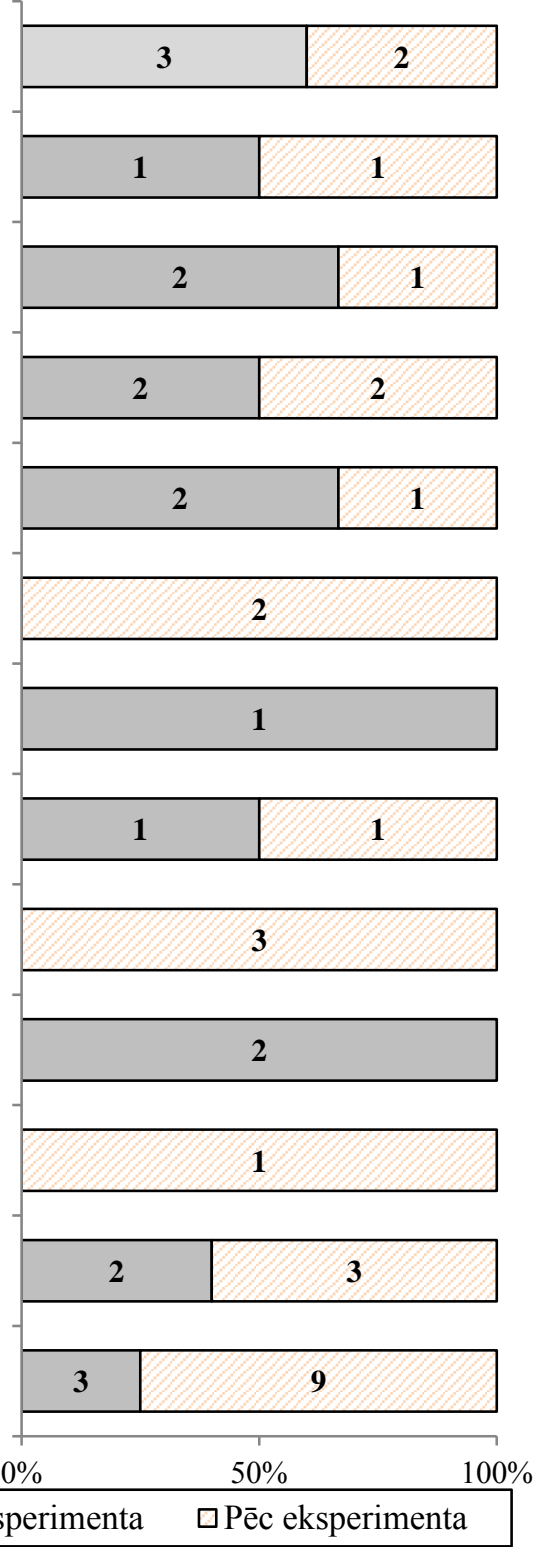

5. att. Profesionālās krīzes noteikšanas kritēriju un rādītāju rezultātu izmaiṇas veidojošā eksperimenta rezultātā

(rezultāti parādīiti absolūtos skaitļos, atbildes "pilnībā piekrītu"). Avots: autores konstrukcija 
Autore secina, ka sievietes, pēc sekmīgas Klienta attīstošās programmas apgūšanas, atzīst, ka ir pārvarējušas krīzi, un pēc dotajiem kritērijiem un rādītājiem ir pozitīvas izmaiņas, kas apstiprina profesionālo krīžu pārvarēšanu.

Profesionālās krīzes pārvarēšanas modeḷa sievietēm ekspertvērtējuma rezultātā Kendela koeficients $\mathrm{W}=0.793 ; \mathrm{p}=0.007$ rāda ekspertu viedokḷu nozīmīgu sakritību. Modelī piedāvātā metodika ir atbilstoša un pietiekama, lai izglītošanās un konsultāciju procesa rezultātā, ievērojot sieviešu karjeru ietekmējošos faktorus, dzimumatbilstības principu un izmantojot profesionālās krīzes noteikšanas kritērijus, tiktu veicināta profesionālās krīzes pārvarēšana.

\section{Secinājumi}

Secinājumi sakārtoti atbilstoši darba sākumā izvirzītajiem uzdevumiem. Darba uzdevumi ir izpildīti un ir rastas atbildes uz pētījuma jautājumiem.

1. Karjeras attīstība sievietēm ir sievietes pašrealizācija gan karjerā, gan ǵimenē visa mūža garumā, ievērojot ekonomiskos, sociālos, psihologiskos un fiziskos karjeru ietekmējošos faktorus. Sievietes karjeras attīstība notiek mūžizglìtības rezultātā. Mūžizglītība - tā ir iespēja sevi izglītot, nodarbināt, paplašināt redzesloku, būt sabiedrībā un būt apmierinātam ar sevi, un rezultātā iespēja rast atbilstošu darbu savai izglītîbai un prasmēm vai uzsākt pašnodarbinātību. Pamatojoties uz zinātnieku P. Džarvis (Jarvis), A. Carlsen, E. Karn̄̄ša, T. Koķes, I. Muraškovskas, A. Ouane, V. Vilcānes atziṇu analīzi var secināt, ka mūžizglītība ar īpaši organizētu gan formālo, gan neformālo izglīîibas sistēmu, sekmē pilnvērtīgu personības attīstību un l̦auj sievietēm veiksmīgāk pielāgoties jaunajām laikmeta un sociālajām pārmain̄ām, un, nemitīgi paaugstinot savu kvalifikāciju vai pārkvalificējoties, lauj nezaudēt darbu vai veiksmīgi veikt karjeras maiņu. Mūžizglìtības procesā iegūtās zināšanas un prasmes atstāj nozīmīgu ietekmi uz sievietes karjeras attīstību visu atlikušo mūžu, kā arī viņas iekḷaušanās darba tirgū veicina visas tautsaimniecības attīstību. Attiecībā uz sieviešu karjeru zinātnieku diskusiju rezultātā ir izveidojušās piecas pieejas sieviešu karjeras attīstībā: sieviešu karjeras atsevišķu teoriju veidošana (G. Psathas, D. Zytowski); esošo teoriju adaptācija (D. Super, J. Holland, L. Fitzgerald, L. Weitzman); visaptverošu sieviešu un vīriešu karjeras teoriju veidošana (L. Gottfredson, H. Astin); individuāli atšķirīgu sieviešu karjeras izvēles izpēte (H. Farmer); sieviešu karjerai piemērojamu sociāli kognitīvo modeḷu veidošana (G. Hackett, N.E. Betz, A. Bandura, R. Lent, S.D. Brown). Autoresprāt, atzīstami ir sociāli kognitīvo modẹ̦u piemērošana sieviešu profesionālo krīzes problēmu risināšanai, kur galvenā nozīme ir paša cilvēka uz savām domām balstīta ideja pārmaiṇu uzsākšanai savā karjerā. Tas nozīmē, ka sievietēm pašām jābūt iniciatorēm uzsākot savu karjeras attīstību vai maiņu. Pētījumu rezultātā, kuros tika izmantota faktoru ranžěšana, par visbūtiskākajiem sieviešu karjeru ietekmējošajiem faktoriem 
respondenti atzīmēja izglìtības līmeni, brīvo darba vietu skaitu dzīves vietā, psihologisko klimatu darba vietā, vadības attieksmi un partnera atbalstu.

2. Krīze karjerā sievietēm mēdz būt kā profesionālās attīstības krīze, kuras cēloṇi var būt šādi: procesi, kas saitīiti ar sievietes vecumu; profesionālās attīstības destrukcijas; jaunības periodā identitātes krīze var izraisīt profesionālo krīzi, kuras izpausmes ir nespēja turpināt darbu vai mācības pēc bērna piedzimšanas; nespēja veikt profesionālo pārorientēšanos un nonākšana konfliktā ar agrāko profesionālo identitāti; nepilna profesionalizācija - mazs konkrēto zināšanu apjoms, lai iegūtu vēlamo profesionālo statusu; emocionālā izdegšana, kas izpaužas kā attieksmes izmaiņa pret darbu un profesiju. Pieaugušo izglītība papildina vai aizstāj pieaugušu cilvēku pamatizglītību, veicina viņu spēju attīstību, bagātina zināšanas, uzlabo profesionālo kvalifikāciju vai pārkvalifikāciju, maina attieksmi un uzlabo uzvedību, tas sekmē sabalansētu un patstāvīgu personības attīstîbu un līdzdalību sociālajā, ekonomiskajā un kultūras dz̄ivē. Svarīga ir pieaugušo lietpratības dinamika, kritiskās domāšanas attīstība, brīva pašrealizācija, nodrošinot sev pilnvērtīgu funkcionēšanu darba tirgū, kas būtībā ir pieaugušo izglīīibas augstākais uzdevums. Mūsdienās ir skaidri vērojama tendence, ka pieaugušo izglìtībā vispopulārākie ir mūžizglītības kursi profesionālās meistarības pilnveidei, kas ir nosacījums veiksmīgai profesionālās krīzes pārvarēšanai.

3. Dzimumatbilstības princips karjeras konsultēšanā sievietēm izsaka sakarību veidošanu starp sieviešu karjeru ietekmējošiem faktoriem, profesionālo krīzi izraisošām situācijām, dzimumatbilstības principa dimensijām un profesionālās krīzes noteikšanas kritērijiem. Veicot pētījuma (no 2015. gada 1. jūnija līdz 2015. gada 18. augustam, kurā piedalījās 1087 sievietes) rezultātu analīzi par dzimumatbilstības principu, ko ir ieteicams ievērot karjeras konsultēšanā sievietēm krīzes situācijās, respondenti atzīst sieviešu pašapziņas celšanu (72\%), dzimumu līdztiesības ievērošanu $(66 \%)$, stereotipu laušanu (57\%), komunikāciju teoriju izmantošanu (50\%). Tātad dzimumatbilstības principa ievērošana karjeras konsultēšanā būtiski sekmē karjeras attīstības problēmu risinājumu sievietēm profesionālās krīzes situācijās.

4. Profesionālā krīze tiek raksturota kā situācija karjerā, kad nepieciešamas pārmaiņas profesijas izvēlē vai maiņā, vai nodarbinātības statusa maiṇā. Profesionālo krīzi izraisa nespēja realizēt profesionālos nodomus, profesionālās adaptācijas grūtības, neapmierinātība ar sociāli profesionālo statusu, jaunu darbību apguves grūtības, veselības pasliktināšanās. Pētījumu rezultātā, kas veikti no 2015. gada 1. jūnija līdz 2015. gada 18. augustam, kurā piedalījās 1087 sievietes, izmantojot autores adaptētos profesionālās krīzes noteikšanas kritērijus un rādītājus pēc E.F. Zejera (Э.Ф. Зeep) un Е.Е. Simaņuka (С.С. Симанюк), var secināt, ka 65 \% 
respondentu bija apmierināti ar profesionālo sagatavotību, $60 \%$ bija apmierināti ar profesionālo izglîtību, taču liels skaits respondentu savā pašvērtējumā uzrādīja neapmierinātību: $57 \%$ bija neapmierināti ar iespējām realizēt sevi izveidojušajās profesionālajās situācijās; 46 \% bija neapmierināti ar savu sociāli profesionālo statusu, $48 \%$ juta psihofiziologiskās izmaiņas un veselības pasliktināšanos, un $26 \%$ atzina profesionālo deformāciju. Tā kā pietiekami liels skaits respondentu atzina neapmierinātību ar savu profesionālo darbību, kas apliecināja krīzes situācijas, tas norāda uz nepieciešamību pēc karjeras atbalsta, ko autore piedāvā izmantojot krīzes pārvarēšanas modeli.

5. Profesionālās krīzes pārvarēšanas modeḷa ietvaros tiek piedāvāta metodika profesionālās krīzes pārvarēšanai, ievērojot dzimumatbilstības principu karjeras konsultēšanas gaitā (sekmēt likumā noteikto dzimumu līdztiesību ievērošanu, komunikāciju teoriju izmantošanu, stereotipu laušanu, sievietes pašapziņas celšanu), realizēt gan karjeras izglītību, gan karjeras konsultēšanas procesu, gan karjeras atbalstu, rodot iespēju katram klientam izmantot personalizētas e-mācību aktivitātes (e-studijas, e-konsultēšanu, ementorismu). Autore tiešsaistes karjeras informācijas pakalpojumu izmantošanu atzīst par karjeras attīstības atbalsta pamatelementu. E- konsultēšana ietver karjeras atbalsta darbību un pakalpojumu nodrošināšanu, izmantojot visas IKT formas, gan karjeras atbalstu tiešsaistē, gan pa tālruni, gan internetā.

6. Aprobējot autores izstrādāto Klienta attīstošo programmu karjeras mainai sievietēm profesionālās krīzes situācijās e-vidē Moodle programmā, veidojošajā eksperimentā piedalījās 18 brīvi izvēlētas sievietes. Analizējot veidojošajā eksperimentā iegūtos datus, no 17 dotajiem kritērijiem, eksperimentā iesaistītajām dalībniecēm pozitīvas izmaiṇas ir novērojamas 9 kritērijos. Pozitīvo kritēriju izmaiñas - Man ir jauna profesionālo vērtību dominante +2, Esmu apmierināta ar savām profesionālās izaugsmes iespējām +3, Esmu apmierināta ar profesionālo izglītību + 1, Es spēju realizēt profesionālos nodomus +1 , Manā dzīve profesionālà karjera man ir nozīmīga +6. Var secināt, ka sievietēm ir cēlusies pašapziņa un pozitīva attieksme pret sevi un minētie profesionālās krīzes noteikšanas kritēriji ir izmantojami, lai konstatētu profesionālo krīzes situāciju sievietēm karjeras atbalsta pasākumos. Programmas aprobācijas rezultātā, veicot krīzes noteikšanas pārbaudi pēc kritērijiem un rādītājiem pirms un pēc eksperimenta, tika konstatēts, ka vidēji visām dalībniecēm pēc eksperimenta $75 \%$ no kritērijiem bija pozitīva karjeras attīstība. Profesionālās krīzes pārvarēšanas modeḷa sievietēm ekspertvērtējuma rezultātā Kendela koeficiens $\mathrm{W}=0.793$; $\mathrm{p}=0.007$ rāda ekspertu viedokḷu nozīmīgu sakritību. Modelī piedāvātā metodika ir atbilstoša un pietiekama, lai izglītošanās un konsultāciju procesa rezultātā, ievērojot sieviešu karjeru ietekmējošos faktorus, dzimumatbilstības principu 
un izmantojot profesionālās krīzes noteikšanas kritērijus, tiktu veicināta profesionālās krīzes pārvarēšana.

7. Pētījumu rezultātā ir sasniegts izvirzītais mērķis - izvērtētas karjeras attīstības iespējas sievietēm profesionālās krīzes situācijās; izstrādātais un aprobētais Profesionālās krīzes pārvarēšanas modelis, kas ietver Klienta attīstošo programmu karjeras maiņai sievietēm profesionālās krīzes situācijās mūžizglīî̄bā tiešsaistē, ievērojot dzimumatbilstības principu karjeras konsultēšanā sievietēm, veicina profesionālās krīzes pārvarēšanu.

8. Pētījuma rezultāti liecina, ka izvirzītās tēzes, tika apstiprinātas:

- apzinot svarīgākos ietekmējošos faktorus sieviešu veiksmīgai karjeras attīstībai un prasmes, kuras var apgūt vai uzlabot, veicina sieviešu profesionālās krīzes pārvarēšanu;

- dzimumatbilstības principa ievērošana karjeras konsultēšanā veicina krīzes pārvarēšanu un sekmē karjeras attīstību profesionālājā krīzē nonākušām sievietēm;

- profesionālās krīzes pārvarēšanas modelis tiek izmantots kā līdzeklis karjeras attīstības veicināšanai profesionālās krīzes situācijās nonākušām sievietēm;

- profesionālās krīzes noteikšanas kritêriji un rādītāji ir izmantojami profesionālās krīzes noteikšanai sievietēm pirms un pēc Klienta attīstošās programmas karjeras maiņai sievietēm profesionālās krīzes situācijās realizācijas.

\section{Turpmākie pētījumu virzieni}

- Kā nodrošināt valsts finansētu pieaugušo mūžizglītības attīstību, lai mazinātu profesionālās krīzes situāciju veidošanos.

- Kā veicināt valsts finansētu karjeras atbalstu krīzē nonākušām sievietēm.

Kā uzlabot karjeras konsultantu sagatavošanas programmas un veicināt vinuu darbības paplašināšanos.

\section{Ieteikumi}

1. Radīt priekšnosacījumus, lai karjeras konsultants būtu pieejams klientiem jebkurā vecumā un jebkurā dzīves situācijā, ne tikai bezdarbniekiem vai skolēniem, bet arī strādājošām sievietēm, piemēram, krīzes centros, izglītības nodaḷās, NVA, augstskolās, citās iestādēs un tiešsaistē.

2. Nodarbinātības valsts aǵentūrā ieviest vairāk IKT, lai konsultanti spētu sekot līdzi visam jaunajam.

3. Sievietēm, kas nonāk profesionālās krīzes situācijās, ir ieteicams izmantot autores izstrādāto Klienta attīstošo programmu karjeras mainai sievietēm 
profesionālās krīzes situācijās karjeras konsultācijās gan e-vidē, gan klātienes konsultācijās, kā arī izmantot profesionālās krīzes noteikšanas kritērijus un rādītājus profesionālās krīzes noteikšanai pirms un pēc programmas apgūšanas.

4. Karjeras konsultantiem ieteicams sabalansēt visas piecas dzīves jomas: darbs, gimene, garīgums, pilsoniskums, brīvais laiks, lai veicinātu savu profesionālo prasmju kvalitātes noturību.

5. Ar izstrādāto Profesionālās krīzes pārvarēšanas modeli sievietēm profesionālās krīzes situācijās un iegūtajiem pētījuma rezultātiem ieteicams iepazīties un tos izmantot karjeras konsultantiem un personālatlases speciālistiem ikdienas darbā ar personālu, lai konstatētu profesionālo krīzi sievietēm, gan veicinātu tās pārvarēšanu.

6. Mācību iestādēm un mācību centriem, ievērojot šī pētījuma rezultātus, ieteicams izstrādāt mācību programmas karjeras izglītîbas jautājumos, lai attīstītu svarīgākās prasmes, kuras nepieciešamas, lai veidotu veiksmīgu karjeru.

7. Darba devējiem ieteicams iepazīties ar karjeru ietekmējošiem faktoriem, censties uzlabot darba vidi potenciālajiem darbiniekiem, kā arī izstrādāt bonusu sistēmu, lai darbinieki justos komfortabli un novērtēti.

8. Sievietēm un karjeras konsultantiem savu iespēju robežās izmantot mūžizglīî̄bas programmas un kursus, lai paaugstinātu savas zināšanas, prasmes un kompetenci, lai veiksmīgi varētu konkurēt darba tirgū.

9. Karjeras konsultantiem pilnveidot karjeras konsultēšanas metodes atbilstoši klienta interesēm un vajadzībām, izmantot karjeras konsultēšanā e-porfolio, e-mentorismu, e-konsultēšanu, izmantot konsultēšanā kvalitatīvas datortehnikas iespējas.

10. Priekšlikumi Valsts izglītīibas attīstības aǵentūrai:

- veicināt profesionālās krīzes mentoru kustības attīstību Latvijā;

- informēt karjeras konsultantus par konsultācijām e-vidē, šo iespēju pasniegt klientiem tā, lai viņus ieinteresētu;

- popularizēt karjeras pakalpojumu saņemšanas iespējas internetā;

- vairāk aktualizēt karjeras konsultēšanu skolās gan pašvaldībās, gan medijos un, protams, sabiedrībā kopumā;

- organizēt mācības, kurās karjeras konsultants var apgūt prasmes un iemaņas IKT jomā, lai varētu vadīt tiešsaistes seminārus un videokonferences, e- konsultācijas un e-mentorismu;

- izglītot karjeras konsultantus IKT lietošanā;

- organizēt interaktīvu mācību materiālu izveidi karjeras attīstības jautājumos klases stundām skolās;

- turpināt attīstīt e-vidi, kurā būs piedāvāts karjeras atbalsts un karjeras konsultācijas, e-konsultācijas. 
The Doctoral Thesis was developed at Latvia University of Agriculture (LLU) during the period from 2012 to 2016

\section{Scientific supervisor}

Vija Dišlere, Dr. paed., assoc. professor of Latvia University of Agriculture (LLU)

\section{Reviewers}

Zenta Anspoka, Dr. paed., professor of Riga Teacher Training and Educational Management Academy (RTTEMA)

Ilze Miķelsone, Dr. paed., assoc. professor of Liepaja University (LU)

Gunārs Strods, Dr. paed., assoc. professor of Rezekne Academy of Technologies (RTA)

Chairperson of the Doctoral Committee of Pedagogy Science of Latvia University of Agriculture

Baiba Briede, Dr. paed., professor of Latvia University of Agriculture

The defence of the Doctoral Thesis will be held at the Institute of Education and Home Economics of the Faculty of Engineering of Latvia University of Agriculture at a public session of the Doctoral Committee of Pedagogy Science on $3^{\text {rd }}$ of May, 2017, at 11 a.m. in Jelgava, 5 J. Cakste Boulevard, Faculty of Engineering, in Room 502.

The Doctoral Thesis and its Summary are available at the Fundamental Library of Latvia University of Agriculture, 2 Liela Street, Jelgava.

(C) Anita Rācene, 2017

(C) Latvia University of Agriculture, 2017

60 copies 


\section{Contents}

Introduction .................................................... 56

1. Career development for women in the context of lifelong education.... 65

1.1. Understanding of the terms career and career development.......... 65

1.2. Role of lifelong education in career development for women........ 66

1.2.1. Adult education in the context of lifelong education for career development............................................ 68

1.2.2. Role of lifelong education measures for career change for women 69

1.3. Information and communication technologies as career guidance enhancement tools ........................................ 70

2. Assessment of professional crisis situations in career development for women ............................................. 72

2.1. Assessment of career development theories applicable to women.................................................

2.2. Theoretical analysis of professional crisis situations and criteria and indicators for identifying such situations.......................

2.3. Theoretical justification of the principle of gender conformity for solving career development problems for women in crisis situations.

3. Developmental experiment on coping with a professional crisis for women..................................................... 84

3.1. Organising surveys and their characteristics.................... 84

3.2. Development of a model and a methodology for professional crisis management.............................................. 86

3.2.1. Results of a survey on career change by women................. 86

3.2.2. Factors influencing women's' careers.......................... 86

3.2.3. Skills contributing to women's career development............. $\quad 90$

3.2.4. Survey on Identifying a professional crisis according to criteria and indicators..............................................

3.2.5. Effects of the principle of gender conformity on women's careers..................................................... 92

3.2.6. Discussion on career change by women ........................ 95

3.2.7. Professional crisis management model .......................... 96

3.2.8. Methodology for professional crisis management............................................. 98

3.3. Approbation and expert evaluation of the Professional crisis 100 management model.

3.3.1. Expert evaluation of the Professional crisis management model and a related methodology.....

3.3.2. Experimental results of the Client-developing programme for career change for women in professional crisis situations.................................................. 102

Conclusions................................................ 104

Proposals.................................................... 108 


\section{Introduction}

The length of the doctoral thesis is 137 pages. The doctoral thesis consists of an introduction, three chapters, conclusions and proposals and 15 annexes. Its theoretical and empirical findings are presented in 32 tables and 23 figures. In total, 244 scientific bibliographical sources in Latvian, English and Russian were analysed by the author.

The author of the doctoral thesis has completed the master study programme Career Consultant and the doctoral study programme Pedagogy at the Institute of Education and Home Economics, Faculty of Engineering, Latvia University of Agriculture. The author has seven-year pedagogical experience and five-year experience in career counselling. Her length of service in accounting and finance is 24 years and experience in managing European Union projects totals five years. The author works at the State Education Development Agency as an expert and a career counsellor.

The doctoral thesis focuses on the problem concerning women in professional crisis situations and the ways of tackling the problem through career guidance and training. In Europe, on average, $63 \%$ of women are employed, compared with $76 \%$ for men. In 2015 in Latvia, approximately 46 thousand women were in a professional crisis situation and had no job; they needed assistance in their career development, which should involve both career counselling and an educational programme.

The lifelong education policy of Latvia is based on an idea that the personal growth and self-enhancement of individuals have to be promoted at every lifetime stage and in all fields of life throughout the entire lifetime, thereby creating prerequisites for building up every resident's entrepreneurial and adaptation abilities and contributing to social inclusion, employment and active civic participation (On the Programme for the Introduction of the Lifelong Education Policy Framework 2007-2013..., 2009; Lifelong Education Policy Framework 2007-2013, 2007/2009; Implementation Pace of the Lifelong Education Policy Framework 2007-2013...., 2011; 2013).

Nowadays, a trend in adult education is that professional skill development courses are the most popular. Adult competence build-up, critical thinking development and free self-realisation are important to ensure one's position in the labour market, which is the key purpose of adult education.

There are significant differences between men and women in the labour market, as the men have higher job positions and work in higher paid labour market sectors (there is a stereotype about men as better managers who are good at exact sciences). For this reason, their wages and salaries, pensions and standard of living are higher than women's. Women in Latvia are paid, on average, $15.4 \%$ lower wages and salaries than men (17.4\% in the EU). In all age groups, poverty risk for women in general is higher than for men both in Latvia and in the EU. Women's situation in Latvia is much worse than in the other 
Member States - the poverty risk rate for women in Latvia is the highest in the EU at 28\% (Rupenheite, 2010).

For this reason, an urgent problem is informal education opportunities for adults (Adult Education in Europe..., 2015). The author's mission regarding the doctoral thesis involves contributing to educating women being in a crisis or career change situation and providing career guidance for enhancing and developing their professional life.

\section{Research topic}

Career development for women in professional crisis situations in the context of lifelong education.

\section{Research object}

Career development for women in adult education in the context of lifelong education.

\section{Research subject}

Career development for women in professional crisis situations.

\section{Research aim}

To assess women's opportunities for career development in professional crisis situations and to contribute to overcoming such situations by means of a Professional crisis management model in the context of lifelong education.

\section{Research questions}

1. How can lifelong education measures influence women's career development?

2. What are professional crisis situations for women?

3. What criteria and indicators are necessary for identifying a professional crisis?

4. What factors contribute to women's successful careers?

5. What criteria and indicators are necessary to identify a professional crisis?

6. What a professional crisis management model is necessary for women in professional crisis situations?

\section{Research tasks}

1. To analyse and review the scientific literature on scientific approaches to women's career development and factors contributing to women's successful careers in the context of lifelong education.

2. To examine professional crisis situations and justify the role of adult education in overcoming a professional crisis.

3. To theoretically justify the application of the principle of gender conformity to tackling career development problems in professional crisis situations.

4. To evaluate, to explore and to adapt criteria and indicators for identifying a professional crisis. 
5. To design and scientifically justify a professional crisis management model and, based on it, to develop a career counselling methodology for professional crisis situations and perform an expert evaluation of the methodology.

6. To perform a developmental experiment in practice in order to approbate the professional crisis management model, collect data, mathematically process the data and analyse, compare and assess the results.

\section{Research methods}

1. Theoretical methods:

- analysis and review of the theoretical literature (pedagogical, psychological, career development and counselling theories),

- analysis of legal acts (documents of the Republic of Latvia and the EU).

2. Empirical methods. Data acquisition methods:

- ascertaining experiment (a questionnaire survey, an expert evaluation),

- developmental experiment (an experiment).

3. Empirical methods. Statistical analysis methods:

- graphic method,

- Kendall's W test (the coefficient of concordance),

- Chi-square $\left(\chi^{2}\right)$ test, confidence level calculations.

\section{Research theoretical framework}

The research theoretical framework was based on theories and scientific findings, developed by several scientists and researchers, as well as international documents on lifelong education and career development.

Adult education in the context of lifelong education: M.T. Brown, A. Carlsen, R.H. Dave, P. Jarvis, E. Karnītis, K.P. Cross, T. Kokse, M.S. Knowles, D. Lieǵeniece, B.C. Lonstrupa, I. Muraškovska, A. Ouane, V. Vilcāne.

Principle of gender conformity: S. Benhabib, K. Giligana, K. Kramarae, C.D. Kasl, N. Slee, D. Tannen, J.T. Wood.

Career counselling for women: H. Astina, A. Bandura, N. Beca, J. Bimroze, S.D. Brown, L. Brown, D.A. Cotter，H. Farmere，R. Fasingere, L. Fitcdžeralde, L. Gotfredsone, Dž. Heketa, Dž. Holands, I. Ķīkule, R. Lents, J.J. Lewis, A.M. Lopez, B. Lovs, M. McMahon, L. Napikoski, L. Nota, S. Osipovs， W. Patton， R.V. Peavy， G. Psathas， J. Rossier， M.L. Savickas, D. Supers, J. Toussaint, L. Veicmane, D. Zitovskis.

Professional crisis management: G. Ancāne, N.K. Denzin, E. Eriksons, L. Frīmens, K.G. Jung, K. Kaprino, K. Levins, C.J. Mettlin, M. Peks, J. Rubenis, E. Simanuks, G. Svence, O.A. Volkova, E. Zejers.

Research methodology: I. Arhipova, S. Bāliņa, A. L. Paura. 
Legal documents: the EU Memorandum on Lifelong Learning, the Europe 2020 Strategy for Smart, Sustainable, and Inclusive Growth, an EU Council resolution, a European Council directive, a European Parliament and Council directive, the European Union Charter of Fundamental Rights, the UNESCO International Commission's report "Education for the $21^{\text {st }}$ Century", the Education Law, the Implementation Pace of the Lifelong Education Policy Framework 2007-2013, the European Lifelong Guidance Policy Network (ELGPN) glossary, the National Development Plan of Latvia 2014-2020 and the Sustainable Development Strategy of Latvia until 2030.

\section{Empirical framework of the research:}

Research place: the Jelgava, Bauska and Dobele Regional Departments of the State Employment Agency (SEA), the Bauska Regional Department of the Continuing Education Centre of BUTS Ltd, social networks, e.g. Draugiem.lv, Facebook.com; Linkedin.com; visidati.lv and the e-environment.

Research participants: 1087 respondents - women (both employed and unemployed, i.e. being in a professional crisis situation) in Latvia and Lithuania, 48 career counsellors in Latvia, 4 experts, 18 participants in the developmental experiment.

Research period: 2012-2016.

\section{Research stages}

Stage 1 (2012-2013). Examinations of the situation. Unstructured observations of women's career change and personal experience reflections on career change. Collection, analysis and review of information on careers, lifelong education and learning, adult education and professional crisis. Examinations of career development theories applicable to women. Description of the nature of and the development of the dimensions for the principle of gender conformity. Development of an experimental methodology for career change and crisis situations. A survey on the use of modern information and communication technologies in career counselling conducted from April to May 2013.

Stage 2 (2013-2014). Studies on women's career change, factors influencing careers and skills contributing to career development. Development of a questionnaire. A survey of women.

Stage 3 (2014-2015). A survey of practising career counsellors on the principle of gender conformity in women's careers conducted from December 2014 to January 2015; it aimed to get insight into the effects of the principle of gender conformity on women's careers. Development of criteria for determining the effects of the principle of gender conformity on women's careers. Development of a professional crisis management model and a related methodology. Development of criteria and indicators for identifying a professional crisis. A survey of women conducted from June to August 2015. An identification of a professional crisis before an experiment by using the criteria developed. A developmental experiment, the approbation of the model 
and the introduction of the methodology. An ascertaining experiment. Development of a methodology for expert evaluations. An expert evaluation of the professional crisis management model conducted from June 2015 to January 2016; processing and analysis of the expert ratings. An identification of a professional crisis according to the criteria developed after the experiment, which was aimed at identifying changes in the professional crisis.

Stage 4 (2016). An analysis and assessment of the experimental results. Processing, analysis, interpretation and assessment of the data derived from the survey of women. Development of conclusions and proposals.

\section{Scientific novelty of the research}

- The role of lifelong education in career development for women in professional crisis situations was assessed and career counselling theories applicable to women were reviewed.

- The principle of gender conformity, which represents associations between factors influencing women's careers and situations causing a professional crisis as well as involves dimensions of this principle and criteria for identifying a professional crisis, was theoretically justified for career counselling for women.

- The most important factors influencing women's career development - the education level, the number of vacant jobs at the place of residence, the psychological climate at the job, the management's attitude and the partner's support - were summarised and justified.

- Criteria and indicators for identifying a professional crisis were adapted.

\section{Practical contribution and significance of the research}

- The professional crisis management model for women in professional crisis situations was developed. Recommendations for overcoming and pedagogical solutions to a professional crisis were developed.

- The professional crisis management model was experimentally approbated. A client-developing programme for career change for women in professional crisis situations for lifelong education purposes was designed, introduced and tested online in the result of the research on women's career change.

- Progressive techniques in career counselling - e-portfolio, e-mentoring and e-counselling - were experimentally approbated.

- Criteria for identifying the effects of observing the principle of gender conformity on women's careers were developed. 


\section{Research limitations}

In approbating the model and in surveys conducted from 2012 to 2016, there were involved:

- women from Latvia (909) and Lithuania (178); the present research was constrained by the fact that the majority of the respondents filled in their questionnaires on the Internet, which means that the women having no computer skills and no available computer and no an Internet connection could not take part in the surveys. Filling in a questionnaire in person was possible only if attending competitiveness enhancement lectures that were selectively delivered by the author at the SEA's departments;

- career counsellors working for the SEA and in ESF projects;

- experts who were invited to do an expert evaluation of the model.

\section{Theses to be defended}

1. Career development for women is a dynamic process that involves the women's self-realisation both in their careers and in their families throughout the lifetime, the women's growth, their personal traits, skills, influencing factors and their interaction as well as change in various life situations. The most important factors influencing women's career development are their education level, which is enhanced through education programmes throughout the entire lifetime, the number of vacant jobs at the place of residence, the psychological climate at the job, the management's attitude, the partner's support, personal traits - purposefulness, enterprise, persistence, the skill to cope with stress, logical thinking and skills to organise their own work, to work in a team, make independent decisions, tackle problem situations and cooperate with other individuals.

2. The principle of gender conformity, which represents associations between the factors influencing women's careers and the situations causing a professional crisis as well as involves dimensions of this principle and criteria for identifying a professional crisis. The observance of the principle of gender conformity in career counselling contributes to overcoming a crisis by women being in professional crisis situations and to the development of their careers.

3. The professional crisis management model is employed as a tool promoting the development of careers of women being in professional crisis situations through implementing the Client-developing programme for career change for women, observing the principle of gender conformity both in career education, in career counselling and in career guidance and through giving any client an opportunity to participate in personalised e-learning activities. 
4. The criteria and indicators for identifying a professional crisis may be used to determine the career crisis for women before and after completing the Client-developing programme for career change for women in professional crisis situations.

\section{Approbation of the research results}

\section{Reports in scientific conferences}

1. Rācene A. (2016). Sieviešu veiksmīgai karjeras attīstībai nepieciešamās prasmes (Skills Necessary for Successfully Developing Women's Careers) (in Latvian). Proceedings of the Education Innovation and Technology Conference LatSTE'2016 - Careers in the Digital Era. 25.10.2016. Liepaja: Liepaja University.

2. Rācene A. (2016). The Model of Career Crisis Management for Women as a Means of Career Development in Relation to Lifelong Education. Report in the 9th International Scientific Conference Rural Environment. Education. Personality. Jelgava: LLU.

3. Rācene A. (2016). Factors Influencing Women's Career Change. Report in the 9th International Scientific Conference Rural Environment. Education. Personality. Jelgava: LLU.

4. Rācene A. (2015). The Principle of Gender Conformity in Women's Career Development. Report in the 8th International Scientific Conference Rural Environment. Education. Personality. Jelgava: LLU.

5. Rācene A. (2014). Role of e-Portfolio in Career Education. Report in the International Scientific Conference Social education VII: Children and youth socialization in the postmodern society. Šiauliai, Lithuania: Šiauliai University.

6. Rācene A., Dišlere V. (2014). Internet Tools as a Kind of Career e-Guidance. Report in the 7th International Scientific Conference Rural Environment, Education, Personality. Jelgava: LLU.

7. Rācene A. (2013). Career Counselling in e-Environment in Latvia. Report in the International Conference New Media for Active Learning in the Digital Age. Šiauliai, Lithuania: Šiauliai University, Distance Studies Centre.

8. Rācene A. (2013). Factors Determining Successful Women Careers. Report in the 6th International Scientific Conference Rural Environment. Education. Personality (REEP). Jelgava: LLU.

9. Rācene A. (2012). Women Skills Needed in the Process of Searching for a Job. Report in International Conference Back to Work. The Role of Validation of Competences in Professional Counselling of Adults. Thessaloniki, Greece: Aristotle University of Thessaloniki.

10. Rācene A. (2012). Factors Hindering the Process of Search for Jobs. Report in the 5th International Scientific Conference Rural Environment. Education. Personality. (REEP). Jelgava: LLU. 
Research papers in generally recognised scientific peer-reviewed publications

1. Rācene A. (2016). The Model of Career Crisis Management for Women as a Means of Career Development in Relation to Lifelong Education. Proceedings of the 9th International Scientific Conference Rural Environment. Education. Personality. Jelgava: LLU, ISSN 2255-808X, pp. 229-238. (Indexed: Thomson Reuters Web of Science; EBSCO Central \& Eastern European Academic Source; AGRIS). Available: http://lufb.llu.lv/conference/REEP/2016/Latvia-Univ-Agricult-REEP2016proceed2255-808X.pdf

2. Rācene A. (2016). Factors Influencing Women's Career Change. Proceedings of the 9th International Scientific Conference Rural Environment. Education. Personality. Jelgava: LLU, ISSN 2255-808X, pp. 219-228. (Indexed: Thomson Reuters Web of Science; EBSCO Central \& Eastern European Academic Source; AGRIS). Available: http://lufb.llu.lv/conference/REEP/2016/Latvia-Univ-Agricult-REEP2016proceed2255-808X.pdf

3. Racene A. (2016). Pilot Research Results of the Client Developing Programme for Women in Professional Crisis Situations. British Journal of Education, Society \& Behavioural Science, Vol. 14 (3), pp. 1-14. Available: http://sciencedomain.org/issue/1577. DOI: 10.9734/BJESBS/2016/24045

4. Racene A., Dislere V. (2016). Didactic Model of Crisis Management for Women in Professional Crisis Situations. British Journal of Education, Society \& Behavioural Science, Vol. 12 (1), pp. 1-16. Available: http://sciencedomain.org/issue/1379. DOI: 10.9734/BJESBS/2016/20619

5. Rācene A. (2015). The Principle of Gender Conformity in Women's Career Development. Proceedings of the 8th International Scientific Conference Rural Environment. Education. Personality. Jelgava: LLU, ISSN 2255808X, pp. 317-328. (Indexed: Thomson Reuters Web of Science; EBSCO Central \& Eastern European Academic Source; AGRIS). Available: http://lufb.llu.lv/conference/REEP/2015/Latvia-Univ-Agricult-REEP2015proceedings.pdf

6. Rācene A. (2014). Development of Women`s Career Pattern in Relation of Employment. Baltic Journal of Career Education and Management. Šiauliai, Lithuania. ISSN 2345 - 0193, pp. 16-23. Available: http://www.scientiasocialis.lt/bjcem/files/pdf/vol2/1623.Racene bjcem Vol.2-1.pdf.

7. Rācene A. (2014). Role of e-Portfolio in Career Education. Proceedings of the International Scientific Conference Social Education VII: Children and youth socialization in the postmodern society. Šiauliai, Lithuania, Šiauliai University, pp. 281-287. Available:

http://content.yudu.com/Library/A32we7/Socialinisugdymas/resources/281.htm

8. Rācene A., Dišlere V. (2014). Internet Tools as a Kind of Career e-Guidance. Proceedings of the 7th International Scientific Conference Rural Environment, Education, Personality. Jelgava: LLU, ISSN 2255-808X, 
pp. 200-207. (Indexed: Thomson Reuters Web of Science; EBSCO Central \& Eastern European Academic Source; AGRIS) Available: http://llufb.llu.lv/conference/REEP/2014/Latvia-Univ-Agricult-REEP2014proceedings.pdf

9. Rācene A., Dišlere V. (2013). A Career Development Support Programme for Women in Professional Crisis Situations. The European Integration Studies, Vol. 7, pp. 42-50, Lithuania. (Indexed: EBSCO) Available: http://www.eis.ktu.lt/index.php/EIS/article/view/4183

10. Rācene A. (2013a). Career Counselling in e-Environment in Latvia. Research papers and abstracts of international conference New Media for Active Learning in the Digital Age. Šiauliai, Lithuania: Šiauliai University, Distance Studies Centre, pp. 26-39.

11. Rācene A. (2013b). Factors Determining Successful Women Careers. Proceedings of the 6th International Scientific Conference Rural Environment. Education. Personality (REEP). Jelgava: LLU, ISSN 2255-808X, pp. 138-145. (Indexed: Thomson Reuters Web of Science; EBSCO Central \& Eastern European Academic Source; AGRIS) Available: http://llufb.llu.lv/conference/REEP/2013/Latvia-UnivAgricult REEP 2013 ISSN 2255-808X.pdf

12. Rācene A. (2012). Women Skills Needed in the Process of Searching for a Job. Medimond International Proceedings Back to Work. The Role of Validation of Competences in Professional Counselling of Adults. Thessaloniki, Greece: Aristotle University of Thessaloniki. ISBN-978-88-7587-661-6, pp. 81-86. (Indexed: Thomson Reuters Web of Science). Available: http://www.edlearning.it/proceedings/moreinfo/20121207_index.pdf

13. Rācene A. (2012). Factors Hindering the Process of Search for Jobs. Proceedings of the 5th International Scientific Conference Rural Environment. Education. Personality. (REEP), Jelgava: LLU, ISSN 2255-808X, pp. 306-312. (Indexed: Thomson Reuters Web of Science; EBSCO Central \& Eastern European Academic Source; AGRIS) Available: http://llufb.llu.lv/conference/REEP/2012/REEP-2012-proceedings-E-ISSN2255-808X.pdf

\section{Other research papers}

1. Rācene A. (2017). Importance of Goal-Setting Tasks in Career Counselling. Proceedings of the 10th International Scientific Conference Rural Environemnt. Education. Personality. Jelgava: LLU. (Accepted for publication on 13.05.2017).

2. Rācene A. (2016). Sieviešu veiksmīgai karjeras attīstībai nepieciešamās prasmes (Skills Necessary for Successfully Developing Women's Careers) (in Latvian). Proceedings of the Education Innovation and Technology Conference LatSTE'2016 - Careers in the Digital Era. 25.10.2016. Liepaja: Liepaja University, pp. 61-69. 
3. Rācene A. (2011). Sieviešu karjeras attīstības teorētiskie aspekti (Theoretical Aspects of Women's Career Development) (in Latvian). LLU TF bachelor and master student scientific conference, the section of pedagogical sciences. 5 May 2011, Jelgava. Available: http://www.tf.llu.lv/getfile.php?id=2713

\section{Concise outline of the doctoral thesis}

Chapter 1 entitled Career development for women in the context of lifelong education reviews the terms career, career development and lifelong education, the necessity for the terms, the positive effects of career development on the job and life and on women's self-confidence and value in the society and family. The chapter justifies the effects of lifelong education measures on one's knowledge, career development for women as well as reviews adult education as a component of lifelong education. The chapter assesses the role of lifelong education in career development for women in professional crisis situations and reviews theories on career counselling for women. It analyses information and communication technologies as tools for raising the quality of career counselling. Chapter 1 consists of three subchapters.

Subchapter 1.1 entitled Understanding of the terms career and career development deals with the interpretations of the terms career and career development by several authors, classifies them into groups as well as gives the author's conclusion.

The term career refers to growth at the job and in private life throughout the lifetime, and its interpretations by various authors are different; therefore, the scientific interpretations of the term career may be classified into groups:

1) a career is defined as growth in relation to only the job or politics promotion in some field of human activity, achievements and fame (Толочек, 2006); a career is a sequence of an individual's job positions, tasks, activities and experiences (Arnold, 1997);

2) a career is defined as growth in relation to lifelong education - the career is long employment or a profession with prospects for development opportunities (Karjeras attīstíbas atbalsts: izglîtíba..., 2008); an individual's work experience development during the course of time (Arthur, Hall, Lawrence, 1989); the career is an individual's development at studies and at the job throughout the lifetime (Watts, 1998);

3) a career is defined as an individual's private life growth and influence - the career is a term related to lifestyle and involves a sequence of job, learning and leisure time activities done by an individual throughout the lifetime (Lifelong Guidance Policy Network (ELGPN) glossary, 2013); the career is a sequence of various socially important tasks related to the individual's job, learning, self-expression and leisure time activities that involve the working life, jobs, job positions and achievements (Lifelong Guidance Policy Network (ELGPN) 
glossary, 2013); the career is an interaction of one's working and private lives throughout the lifetime, including the balance of paid and unpaid employment as well as involvement in learning and education (Lifelong Guidance Policy Network (ELGPN) glossary, 2013).

After summarising the various views on career theories, the author concludes that a career is an individual's purposeful activity aimed at achieving the private and professional goals throughout the lifetime.

Career development is defined as the process of learning and working as well as of self-actualisation of other individually significant kinds that takes place throughout the lifetime (Karjeras attīstības atbalsts: izglīīiba.., 2008).

Career development is defined as a set of economic, sociological, psychological, physical, educational and contingency factors that shape the individual's career (Sears, 1982).

Nowadays, career development is characterised as a dynamic process that involves the individual self-realisation, the environment and related interactions and changes. Career development not always means advancement or career development in breadth; career decline is also possible. A career at adult age is influenced by the life role of the current life period.

Since the career development level is very individual for any personality, some individual can be satisfied with a simple job for a long period, which requires no high qualification, while another one wishes to educate oneself and take higher and more responsible job positions; therefore, one can say that the self-realisation needs of individuals are very diverse - the needs are very individual and change over time; for this reason, the author did not focus on designing special career development indicators but focused on analysing professional crisis situations and developing criteria for identifying a professional crisis.

After summarising the theoretical findings, the author concludes that career development for women involves their self-realisation both in their careers and in their family throughout the lifetime, taking into consideration economic, social, psychological and physical factors that influence the career.

In her research, the author focused on examining the factors influencing women's careers and the women's personal traits and skills and identified the most important ones that affect and promote the successful development of their careers.

In Subchapter 1.2 entitled the Role of lifelong education in career development for women, the author explains and justifies the role of lifelong education in women's career development based on research papers by various authors.

Lifelong education is defined as an educational process taking place throughout the lifetime, which is based on the changing needs for knowledge, skills and experience to enhance or change one's qualification according to labour market requirements and one's own interests and needs. 
Lifelong education combines informal learning and formal education, develops inherent abilities along with new competences (Lifelong Education Policy Framework ..., 2007/2009).

Lifelong education represents all the learning activities that were done throughout the lifetime and that resulted in enhanced knowledge, technological competence, skills and qualifications owing to personal, public or professional reasons (Lifelong Guidance Policy Network (ELGPN) glossary, 2013).

The author finds that since career development takes place throughout the lifetime and lifelong education is a process extending throughout the lifetime, both terms are interrelated. Career development is possible if an individual educates oneself, enhancing one's own skills and contributing to the personality's growth, which, however, can be done through taking lifelong education courses and programmes; that is why a great role in women's career development is played by lifelong education.

The priorities set in the Europe 2002 strategy involve the promotion of sustainable and inclusive growth based on high employment rates and a target to reduce the number of individuals facing poverty until 2020. As of the end of March 2015, Latvia's State Employment Agency had registered 46240 unemployed women, and the employment rate for women in Latvia was lower than for men, which evidenced that the women needed career counselling and guidance the most, which would involve both consultations and an educational programme. The author suggests such a programme in her doctoral thesis, summarising the whole set of support measures.

Lifelong education is viewed as a whole, which begins with the moment of birth and continues through to the end of life. Individual motivation to learn and educational opportunities are the key factors to successfully implement lifelong education.

In the continuous process of lifelong education, the greatest role is played by informal learning taking place outside schools, colleges and universities.

When researching informal education, M.S. Knowles found that the best ways were to use the group and forum approaches to managing informal education activities.

Two resolutions by the Education Council of the European Union (passed in 2004 and 2008) have justified the need for stable career support measures throughout the lifetime to ensure that skilful individuals can manage their education process and careers and transit from one educational and/or employment stage to another. The resolutions focused on four priorities:

- build-up of career management skills;

- availability of career guidance services;

- assurance of the quality of career services;

- coordination of the consistency of services (Resolution of the Council..., 2010; Lifelong career guidance policy: work continues, 2011; Lifelong career guidance in Europa..., 2011). 
The author concludes that the development of an individual takes place owing to lifelong education, and the lifelong education is an opportunity to educate oneself, employ oneself, expand one's horizons, be in the society and be satisfied with oneself and, consequently, to find a job appropriate for one's education and skills or start up self-employment. In the author's opinion, lifelong education has to be perceived as a kind of education taking place throughout the lifetime. It is based on an inner need or a need caused by exogenous factors to acquire and continue enhancing one's knowledge and skills. Lifelong education with a specially organised system of both formal and informal education contributes to the comprehensive development of a personality and allows the individual to successfully adapt to social changes in the new era and, if persistently enhancing his/her qualification or if acquiring a new qualification, to retain his/her job.

Lifelong education means acquiring an education and a new knowledge throughout the lifetime, regardless of age and education or social status; therefore, adult education is important in Latvia, which is associated with the considerable increase in unemployment.

Subchapter 1.2.1. The subchapter is entitled Adult education in the context of lifelong education for career development, and it justifies the urgency and significance of adult education.

Adult education is defined as a multifaceted process of education that ensures the development and competitiveness in the labour market of a personality throughout the lifetime (Education Law, 1999)

As pointed out by T. Koķe (Kokse, 1999), K.P. Cross (Cross, 1981) used the terms continuous education and adult education as synonyms in the early 1980s. At the turn of the 1980s and 1990s, M.S. Knowles (Knowles, 1988) did not see any specific differences among the terms adult education, continuous education and further education, stressing that an essential and common feature of education was its continuity.

The UNESCO International Commission's report "Education for the $21^{\text {st }}$ Century" (Learning the Treasure within, 1996) mentions four pillars, which education is based on throughout the lifetime:

- learning to know;

- learning to do;

- learning to live together;

- learning to be.

Adult education for women can help acquire new skills or better understand the surrounding environment, as well as to enhance their life and broaden its boundaries; participants of the courses train their abilities to be together and cooperate with others.

It becomes urgent for adults to enhance their professional proficiency and competence to promote their careers at their jobs. Not knowledge and skills but the change in professional proficiency and competence and the way an individual 
uses them, ensuring his/her position in the labour market, are the goal for professional enhancement in education.

The most complicated problem is to assess inner qualitative changes in a personality's understanding, values, attitudes and self-confidence. Assessments and self-assessments promote the development of critical thinking in individuals, their reflection and free and humane self-realisation, which, in a broader context, is a prerequisite for the stabilisation of principles of democracy that actually is the greatest task of adult education.

D. Liegeniece (2002), based on the findings of M.S. Knowles (Knowles, 1988), concludes that adults get ready to learn when they feel a need to know and do something in order to effectively transform some aspect of their life. M.S. Knowles (Knowles, 1988) pointed out that the readiness of adults to learn is associated with the following factors:

- understanding of what they need to know;

- focus on real problems instead of study subjects;

- inner motivation to learn.

Lifelong education gives a positive result if an individual can use his/her acquired knowledge at the job and in his/her life and, therefore, his/her self-confidence and value in the society rise.

Subchapter 1.2.2. The subchapter is entitled the Role of lifelong education measures for career change for women. In the subchapter, the author justifies the large role and effects of lifelong education measures when making decisions on career change; the subchapter also summarises the opportunities for getting new skills.

Career development for women is more complicated than for men, as there are a number of internal and external barriers, including family responsibilities, the life role, employment, the surrounding environment, traditions, stereotypes that constrain the choice of a profession, career growth and career change.

Based on an analysis of the findings by P. Jarvis, A. Carlsen, E. Karnītis, T. Kokse, I. Muraškovska, A. Ouane and V. Vilcāne, one can conclude that lifelong education together with both formal and informal education contributes to the comprehensive development of the personality and allows women to easier adapt to social changes in the new era and, if persistently enhancing their qualifications or if acquiring a new qualification, to retain their jobs or successfully do career change.

Nowadays, when the labour market situation changes fast and new technologies are introduced in many industries, the requirements for employees increase, thereby creating a need for enhancing their professional skills and restructuring the knowledge. If an individual cannot meet the new requirements, he/she becomes unemployed, which does not contribute to the sustainable development of the society. Lifelong education is a way how to tackle this problem holistically at national level and how individuals can enhance their 
knowledge throughout their lifetime, regardless of their age, current education or social status. Within lifelong education, women too have to enhance themselves and build up their professional skills, change their attitudes, values and selfconfidence in terms of personality qualitative growth in order to ensure they can cope with any life situation and find new perspectives. Various informal education courses aimed at enhancing professional proficiency, which have been taken by women in professional crisis situations because of their inner needs or exogenous factors, give an opportunity to broaden their horizons and promote the development of critical thinking in the women and their reflection, personal autonomy, and free and humane self-realisation. In a broader context, the mentioned qualities are prerequisites for the stabilisation of principles of democracy that actually is the greatest task of adult education. Through learning, self-enhancement and self-development, the self-confidence and social value of individuals are built up, which is a way towards a life full of satisfaction that involves their satisfaction at the job and in their private life. Accordingly, there are positive changes in the competence of individuals learning throughout their lifetime, which is one of the preconditions for succeeding in the labour market and also the basis for the sustainable development of the entire society. In this way, lifelong education gives an opportunity for women in crisis to achieve their own goals, to acquire an education and to enhance their skills, which provides new career opportunities and opportunities for self-realisation.

Subchapter 1.3. The subchapter is entitled Information and communication technologies as career guidance enhancement tools. It assesses opportunities to modernise and improve career guidance services and to enhance or acquire new skills by women through using the career guidance services.

With the fast development of information and communication technologies and the introduction of e-studies at universities and secondary schools and in courses, the use of career e-counselling has become urgent. The purpose of introducing online career guidance is to help people who need to enhance their skills, obtain necessary information and receive assistance from a career counsellor, and counselling, information resources and interactive assessment tools are available any time and any day (Career support measures..., 2010).

ICT competence has become an essential indicator of general competence. The career development support system consists of three major elements:

- information (preparation and submission);

- career education (services, courses, programmes);

- career counselling (assistance in career planning, identification of professional appropriateness, job trials, build-up of job search and retention skills) (Conception Career development support system ..., 2006).

E-studies allow traditional studies of any kind to enter the electronic environment; the e-studies usually consist of video, audio and textual materials 
as well as of animations and computer simulations. The programmes and processes of e-studies involve online-based learning, computerised studies, virtual classes and digital cooperation, in which the content to be learnt is supplied using the Internet (both the intranet and extranet), audios or videos, satellite TV and DVDs. E-studies may take the form of self-education and may be guided by an instructor and involve media format texts, figures, animations, videos and audios (Elearning-companion.com, 2015).

Online services give new opportunities in education. The Internet becomes a study aid as well as broadens opportunities to work (Guthrie, McCracken, 2010). E-counselling is a kind of counselling or assistance that is provided using ICT, where a career counsellor is or is not directly involved. E-counselling includes career guidance activities Using the ICT in all forms:

- online career guidance;

- career guidance via phone;

- career guidance via the Internet.

Information and communication technologies for career guidance are the technologies that ensure information is electronically entered, stored, acquired and processed as well as sent and disseminated.

In general, online information and career guidance services involve a range of information supply modalities: simple or structured hypertext websites; downloadable files; databases and multimedia resources.

A survey of practising career counsellors was conducted in April-May 2013 to get insight into how the career counsellors use modern information and communication technologies in their career counselling. The survey involved 42 practising career counsellors aged 24-60. Career guidance through information and communication technologies was done by 37 counsellors involved in the survey. The purpose of the survey was to examine the use of information and communication technologies in career guidance. The research results were as follows:

- career guidance by means of IT broaden counselling opportunities, give additional information and any client has an opportunity to receive answers to unclear questions;

- for career guidance in Latvia, practising career counsellors mainly used e-mail (28), followed by the Internet (18) and a phone (16); distance career services were not provided by 12 , while 7 chose the reply option "other";

- however, the practising career counsellors did not use websites in career guidance; this may be explained by the fact that they lacked information and skills how to use the websites as well as there were no examples of best practices in this regard. Of the respondents, 10 admitted they used other websites, such as Skype, draugiem.lv, facebook.com, e-klase, a school's intranet, www.viaa.gov.lv, www.nva.gov.lv, inbox.lv and e-klase.lv. Of them, 7 admitted they 
used the website www.pbworks.com because they worked as counsellors in an ESF project managed by the Faculty of Education, Psychology and Art, University of Latvia; the project used this website. One respondent admitted using the website moodle.com.

- an analysis of the respondents' replies reveals that the advantages of career e-counselling are as follows: first, it is an opportunity to get career counselling and participate in group activities regardless of the location; second, career counselling takes place during an acceptable time for both sides; third, it involves lower costs - clients do not have to travel to a career centre to get their counselling; fourth, the exercises given by career counsellors give an opportunity for clients to build up their skills and knowledge and tackle their problems; fifth, ICT skills are acquired during the career counselling;

- according to the respondents, the key disadvantages of career e-counselling are as follows: first, there is no direct contact between a career counsellor and a client; second, no direct and immediate feedback from the career counsellor; third, clients lack knowledge and skills to work with a computer and new technologies; fourth, career counselling through a website hinders fast information exchange; fifth, a career guidance session can last for too long because of the client's negligence or the session can yield no result.

Chapter 2 entitled Assessment of professional crisis situations in career development for women focuses on career development theories applicable to women. It theoretically analyses five approaches to women's career development, examines professional crisis situations and theoretically justifies the principle of gender conformity in career development for women and suggests criteria and indicators for identifying a professional crisis. Chapter 2 consists of three subchapters.

Subchapter 2.1. The subchapter is entitled Assessment of career development theories applicable to women. It analyses scientific findings on the five approaches to career development for women and reviews the career development theories selected by the author, which could be applicable to career guidance for women in a professional crisis.

Women's career development has been researched by a number of scientists. J. Holland (Holland, 1973) considered women's career development to be very similar to that for men. Career growth stages developed by D. Super (Super, 1957, Super, 1980; Super, 1990) involved women's career development as well. S. Osipow (Osipow, Littlejohn, 1995), however, pointed out the inability of career theories to explain women's careers as a separate group of careers. L.E. Isaacson and S.D. Brown (Isaacson, Brown, 1993) referred to women as a "special group" that goes beyond the existing theories. V. Patton and M. McMahon (Patton, McMahon, 2006) analysed ecological and intercultural 
aspects in women's career development. J. Bimrose pointed out that women and men were evaluated differently and analysed the ways how women could successfully integrate into the labour market (Bimrose, 2008).

C. Chen focused on the specifics of counselling for women, how to cope with the job and family responsibilities without conflicts (Chen, 2008). L. Belanger suggested examples for women how to engage and succeed in business (Belanger, 2015). M.B. Arthur, D.T. Hall, B.S. Lawrence, A.B. Rochlen and D.P. Bloch analysed career theories in general as well as focused on the reasons, factors and commitments that contributed to women's career development (Arthur, Hall, Lawrence, 2008; Bloch, 2005; Applying counselling theories, 2007). Further, the author focuses on the five approaches to career development for women.

The first approach involves the creation of specific theories on women's careers. The creation of such theories is necessary due to different needs, perspectives, choices, priorities and kinds of careers. Such factors as marriage, satisfaction, family finances, social affiliation, parent education and employment, values, social mobility and the choice of friends for women are different compared with those for men.

D. Zytowski (Zytowski, 1969/2011) highlighted three employment factors for women: age for beginning employment; time spent at the job; and extent of engagement in employment.

The second approach involves the adaptation of existing theories. D. Super (Super, 1957) highlighted seven patterns of women's careers:

- stable homemaking career;

- conventional career;

- stable working career;

- double-track career;

- interrupted career;

- unstable career;

- multi-trial career.

The author integrated D. Super's theory into her Client-developing programme classes as well as developed an exercise for women, in which the women have to analyse their career pattern according to the seven women career patterns suggested by D. Super.

J. Holland (Holland, 1973; Holland, 1985; Holland 1994) described six types of individuals and their employment and believed that there was a strong association between the pattern of interests of individuals and their employment abilities (Career counselling techniques, 2009).

The third approach involves the creation of comprehensive theories on women and men. L. Gottfredson (Gottfredson, 1981) and H. Astin (Astin, 1984) created theories on careers of both genders. H. Astin (1984) combined motivation, job role expectations, gender role socialisation and opportunity structures. However, L. Gottfredson expressed an idea that the formation of 
a personality structure was influenced by gender, the social group, intelligence, interests, values and their interaction with views on employment.

The fourth approach is associated with research on women's choice of specific, individually different careers. H. Farmer (Farmer, 1997) suggested a theory that combined factors of an individual's origin (gender, race, the social stratum, the location of the school, age) with the individual's psychological factors (self-assessment, values, attitude to the home and perception of achievements) and environmental factors (the public's attitude to women's jobs, support of teachers and parents).

The fifth approach involves the creation of social cognitive models applicable to women's careers. Scientists J. Hackett and N.E. Betz (Hackett, Betz, 1981; Hackett, 1995) sought to explain the effects of socialisation on career formation using individual self-confidence indicators suggested by A. Bandura (Bandura, 1977): demonstration of achievements, use of the experience of others, verbal encouragement, emotional inspiration (as efforts at the highest level; as self-confidence at the lowest level).

The author used the second approach - the adaptation of existing theories to women - and the fifth approach - the application of social cognitive models to overcoming women's professional crises for the development of her clientdeveloping programme.

Further, the author reviewed the selected career development theories that could be applied in career guidance for women in crisis.

Professional constraint theory. The term glass ceiling is used in respect to women's careers, the development of and constraints on their careers. The professional constraint theory is consistent with the fourth approach to career development.

In policy documents the glass ceiling is referred to as vertical labour market segregation - the tendency of men and women to take different job positions in the same profession or group of professions (Ķikule, 2006).

In her research studies, J. Toussaint pointed out that the glass ceiling meant the economic suppression of women (Toussaint, 1993). The term glass ceiling refers to an invisible barrier that does not allow women to continue succeeding in their careers. This metaphor is often used in relation to women who are not able to climb up the career ladder at their job. Theoretically, there are no problems to climb up the career ladder; the barriers are due to stereotypes and that is why the explanation says that the ceiling is made of glass.

The glass ceiling involves barriers to vertical career growth, inequality in pay for the same work and the loss of professionalism due to pregnancy and childbirth leave.

Discrimination at the job is usually due to several essential factors: age, gender and nationality; therefore, it is difficult to distinguish the discrimination that is faced by an employee because of being a man or a woman (Ķikule, 2006).

The legislation of the Republic of Latvia stipulates equal attitude to men and women. It is difficult to regulate the glass ceiling phenomenon by means of 
only legislation because it is, to a great extent, associated with the public's understanding and stereotypes of gender roles.

Community interaction theory. The theory considers the changing life of an individual and the personality as a whole, his/her local interpersonal bonds that associate him/her with important people and the overall structure of circumstances as the determinant factor in the choice of a profession (Wolfe, Kolb, 1980).

The theory focuses on the public's influence on an individual's decisionmaking. B. Low suggested five key ways how to the mentioned influence is made:

- role expectations - decisions are made based on what is considered to be acceptable to the family or community;

- feedback - information individuals have about the strengths and weaknesses of a profession as well as whether the profession is appropriate for particular goals;

- support - necessary skills have to be acquired and built-up;

- simulation - availability of influential examples and identification with others when thinking of a job;

- information - a chance to find out about various opportunities.

If focusing on this idea in research on the effects of a community, the public or the family on a client's career, the theory helps counsellors get rid of prejudice and better understand the way how the client has made his/her career and how to give him/her support in future.

Racial, ethnical and cultural aspects in career development. Career theories regarding racial and ethnical groups are divided into three categories. Traditional theories that:

1) focus on minority aspects too: J. Holland, D. Super (Holland, 1973; Holland, 1985; Super, 1957, Super, 1980; Patton, McMahon, 2006);

2) have broader theoretical models applicable to diverse cultures:

- self-efficacy theory by J. Hackett and N.E. Betz (Hackett, Betz, 1981; Hackett, 1995);

- social cognitive model by R. Lent and J. Hackett (Bandura, 1986; Lent, Brown, Hackett, 1994, 2000, 2002);

- social learning theory of career choice by J. Krumboltz (Krumboltz, 1994; Osipow, Fitzgerald, 1996; Mitchell, Krumboltz, 1996; Sharf, 2006; Krumboltz, 2006; Bimrose, 2016);

- socio-psychological model by L. Gottfredson (Gottfredson, Lapan, 1997; Gottfredson, 1981; Gottfredson, 2002; Hauser, Tsai, Sewell, 1983);

- system theory, intercultural perspectives by V. Patton and M. McMahon (Patton, McMahon, 2006);

- life design paradigm in career development by M.L. Savickas, L. Nota and J. Rosier (Savickas, Nota, Rossier, 2009).

3) theoretical attempts to take into account cultural specifics: 
- minority career development, instead of racial differences (Osipow, Littlejohn, 1995);

- with regard to careers, it is advised to use the terms ethnic group and cultural group, as the terms race, ethnic affiliation and minority in modern social culture are too broad and it is difficult to distinguish them (Leong, Brown, 1995).

Surveys of the women were conducted to test how effective the mentioned theories are in practice and how their theoretical findings can be used in career guidance for women and to familiarise women with the diversity of theories on women's career development, which are described in detail in Chapter 3.

Subchapter 2.2. The subchapter is entitled Theoretical analysis of professional crisis situations and criteria and indicators for identifying such situations. It examines professional crisis situations, gives the characteristics of professional crises during the development of a personality, specifies the causes and factors of a professional crisis and summarises the key kinds of professional crisis with regard to a woman's age. In addition, the author has selected and adapted criteria and indicators for identifying a professional crisis based on the theoretical findings made by E.F. Zeer and E.E. Simanyuk, summarised the criteria according to the dimensions of the principle of gender conformity, based on which a survey of career counsellors was designed, and examined the effects of observance of the principle of gender conformity on women's careers.

A crisis in a career is a crisis in professional development, which is caused by (Denzin, Mettlin, 1972; Волкова, 2005):

- processes related to an individual's age;

- professional development destructions;

- identity crisis in the period of adolescence can cause a professional crisis;

- professional crisis could be associated with a personality's identity if the personality cannot objectively do his/her professional reorientation and gets into conflict with the earlier professional identity;

- crisis could be caused by incomplete professionalization;

- crisis is caused by a situation where a reference professional group is not ready to accept a particular individual;

- emotional burnout is considered a professional crisis, as it manifests itself as a change in attitude to the job and profession.

K.G. Jung (Юнг, 1996) stressed that a constructive solution to a crisis is individualisation - self-development and self-formation.

Changes take place in any crisis, and the changes provide opportunities for development. Prerequisites for coping with a crisis, according to M. Pek (Пек, 1996) are as follows:

- emotional flexibility, emotional support to children and their parents;

- real assessment of life plans/goals; 
- awareness of the constrained lifetime;

- correction of the lifestyle;

- creation of a new image of the "ego";

- acceptance of one's situation as normal, as the one contributing to stability.

The kinds of professional crisis for women in relation to their age stages are summarised in Table 1 .

Table 1

Key kinds of professional crisis in relation to women's age stages

\begin{tabular}{|c|l|l|}
\hline $\begin{array}{c}\text { Age } \\
\text { stages }\end{array}$ & \multicolumn{1}{|c|}{ Crisis } & \multicolumn{1}{c|}{ Crisis characteristics } \\
\hline $19-20$ & $\begin{array}{l}\text { Profession choice } \\
\text { crisis (3eep, } \\
\text { Симанюк, 2005) }\end{array}$ & $\begin{array}{l}\text { Change in the motives for learning and professional } \\
\text { activity. Profession choice correction. The lack of } \\
\text { practice that hinders women from finding a job. }\end{array}$ \\
\hline $40-45$ & $\begin{array}{l}\text { Psychological and } \\
\text { physiological } \\
\text { crisis for women } \\
\text { (Svence, 2003). }\end{array}$ & $\begin{array}{l}\text { The life of women aged 40-45 can bring new senses } \\
\text { about themselves as personalities; women can have, } \\
\text { for example, a sense that "finally, I am what I am and } \\
\text { I am not afraid of what others think about me". } \\
\text { Women start something new, bring changes in their } \\
\text { education and professional career. }\end{array}$ \\
\hline $60-62$ & $\begin{array}{l}\text { Preretirement } \\
\text { professional crisis }\end{array}$ & $\begin{array}{l}\text { Finding and changing a job is problematic; the loss of } \\
\text { the job. }\end{array}$ \\
\hline
\end{tabular}

Source: author's construction

The author characterises a professional crisis as a situation in one's career where some changes are necessary regarding the choice or change of a profession or employment status (from an employee to an employer). Overcoming the crisis requires the guidance of a career counsellor and a mentor whose descriptions are summarised in the professional crisis management model.

The author has selected and adapted the criteria and indicators for identifying a professional crisis based on the theoretical findings by E.F. Zeer and E.E. Simanyuk (Table 2). A criterion is defined as a feature, based on which something is assessed, defined or classified (AkadermTerm, 2016d). Criteria for identifying a professional crisis are features, by means of which one can determine whether a situation is or is not a professional crisis for a woman. The criteria are expressed as an indicator showing the situation for the woman; the indicator is expressed in points from 1 to 5 , where 1 means a very negative rating (fully disagree), 2 means a negative rating (disagree), 3 means a neutral rating, 4 means a positive rating (agree) and 5 means a very positive ration (fully agree). 
Table 2

Criteria and indicators for identifying a professional crisis

\begin{tabular}{|l|l|l|l|l|l|l|}
\hline No & \multicolumn{3}{|c|}{ Criteria } & \multicolumn{5}{|c|}{ Indicators } \\
\hline 1 & $\begin{array}{l}\text { A professional career is important in } \\
\text { my life }\end{array}$ & 1 point & 2 points & 3 points & 4 points & 5 points \\
\hline 2 & $\begin{array}{l}\text { I am able to fulfil my professional } \\
\text { intentions }\end{array}$ & 1 point & 2 points & 3 points & 4 points & 5 points \\
\hline 3 & $\begin{array}{l}\text { I am satisfied with my professional } \\
\text { education }\end{array}$ & 1 point & 2 points & 3 points & 4 points & 5 points \\
\hline 4 & $\begin{array}{l}\text { I am satisfied with my professional } \\
\text { preparedness }\end{array}$ & 1 point & 2 points & 3 points & 4 points & 5 points \\
\hline 5 & $\begin{array}{l}\text { I have professional adaptation } \\
\text { problems }\end{array}$ & 1 point & 2 points & 3 points & 4 points & 5 points \\
\hline 6 & $\begin{array}{l}\text { I have problems to learn new major } \\
\text { activities }\end{array}$ & 1 point & 2 points & 3 points & 4 points & 5 points \\
\hline 7 & $\begin{array}{l}\text { My professional expectations do not } \\
\text { match reality }\end{array}$ & 1 point & 2 points & 3 points & 4 points & 5 points \\
\hline 8 & $\begin{array}{l}\text { I am satisfied with my professional } \\
\text { growth opportunities }\end{array}$ & 1 point & 2 points & 3 points & 4 points & 5 points \\
\hline 9 & $\begin{array}{l}\text { I need professional self- } \\
\text { determination }\end{array}$ & 1 point & 2 points & 3 points & 4 points & 5 points \\
\hline 10 & $\begin{array}{l}\text { It is difficult for me to implement my } \\
\text { professional self-determination }\end{array}$ & 1 point & 2 points & 3 points & 4 points & 5 points \\
\hline 11 & $\begin{array}{l}\text { I have new dominant professional } \\
\text { values }\end{array}$ & 1 point & 2 points & 3 points & 4 points & 5 points \\
\hline 12 & $\begin{array}{l}\text { I am not satisfied with my } \\
\text { opportunities for self-realisation in } \\
\text { existing professional situations }\end{array}$ & 1 point & 2 points & 3 points & 4 points & 5 points \\
\hline 13 & $\begin{array}{l}\text { I am not satisfied with my social and } \\
\text { professional status }\end{array}$ & 1 point & 2 points & 3 points & 4 points & 5 points \\
\hline 14 & $\begin{array}{l}\text { I feel professional psychological and } \\
\text { physiological changes in me and the } \\
\text { deterioration of my health }\end{array}$ & 1 point & 2 points & 3 points & 4 points & 5 points \\
\hline 15 & $\begin{array}{l}\text { In my professional work it is not } \\
\text { clear to me what I am responsible for }\end{array}$ & 1 point & 2 points & 3 points & 4 points & 5 points \\
\hline
\end{tabular}


Continuation of the Table 2

\begin{tabular}{|l|l|l|l|l|l|l|}
\hline No & \multicolumn{2}{|c|}{ Criteria } & \multicolumn{4}{|c|}{ Indicators } \\
\hline 16 & $\begin{array}{l}\text { In my professional work I assume an } \\
\text { increasing number of } \\
\text { responsibilities, more than I would } \\
\text { ever be able to do because I cannot } \\
\text { say "no" }\end{array}$ & 1 point & 2 points & 3 points & 4 points & 5 points \\
\hline 17 & $\begin{array}{l}\text { I have a professional deformation } \\
\text { (changes in essential personal traits } \\
\text { and indicators measuring personality } \\
\text { influenced by professional activity } \\
\text { and individual traits) }\end{array}$ & 1 point & 2 points & 3 points & 4 points & 5 points \\
\hline
\end{tabular}

Source: author's construction based on Зеер, Симанюк, 2005

A professional crisis is caused by an inability to fulfil one's professional intentions, professional adaptation problems, dissatisfaction with one's socioprofessional status, problems with learning new activities and health deterioration. The criteria and indicators for identifying a professional crisis were used in a study surveying respondents before and after the developmental experiment to find out whether the professional crisis management model developed by the author has yielded expected results.

Subchapter 2.3. The subchapter is entitled Theoretical justification of the principle of gender conformity for solving career development problems for women in crisis situations. It examines gender communication theories and theoretically justifies the use of the principle of gender conformity in solving career development problems for women in professional crisis situations.

There is an opinion that individuals have a limited choice of their profession and employment with respect to their gender and ethnic and social affiliation.

The strategy for equality between women and men stresses the contribution of gender equality to economic growth and sustainable development and supports the integration of the gender equality dimension into the strategy Europe 2020. Increasing the current employment rate of $69 \%$ for individuals aged 20-64 to at least $75 \%$, including increasing the employment rate for women, is one of the key targets of Europe 2020 (Europe 2020. Strategy for Smart, Sustainable, and Inclusive Growth, 2010). However, gender disparities still exist in the labour market, and women are still more represented in low-pay industries, while they are insufficiently represented in job positions where decisions are made. The average gender equality index for the EU is 54 ( 1 means no gender equality and 100 means absolute gender equality). The index for Latvia is lower than the EU average, at 44.4. The gender equality index shows average scores for the following gender equality domains: work, money, knowledge, time, power and health. 
In any domain, there is a gap between women and men; the reason is social stereotypes about the role, behaviour, external appearance and mental abilities of one or the other gender. The public's assumptions on femininity and masculinity influence communication in the family, at the job and in the community; therefore, the communication theories that explain differences in communication between women and men could be very useful to understand how to make successful careers (Table 3).

Table 3

Gender communication differences

\begin{tabular}{|c|l|l|}
\hline No & \multicolumn{1}{|c|}{ Theories } & \multicolumn{1}{c|}{ Key ideas } \\
\hline 1 & $\begin{array}{l}\text { Theory on gender } \\
\text { communication } \\
\text { styles } \\
\text { (Tannen, }\end{array}$ & $\begin{array}{l}\text { The theory aims to acknowledge and assess } \\
\text { communication with the opposite gender and to achieve } \\
\text { mutual respect and understanding between women and } \\
\text { men. The theory stresses that particularly differences in } \\
\text { Tannen, 1992a; } \\
\text { Tannen 1992b) } \\
\text { communication are the cause of misunderstandings and } \\
\text { confusions. Communication differences in a team - } \\
\text { cooperation and conversation are important for women and } \\
\text { the change of rules of game does not create any problems. } \\
\text { Women use a conversation to express their interest in other } \\
\text { individuals and their needs in order to cooperate. Women } \\
\text { use a conversation as a tool to generate ideas, solve } \\
\text { problems and establish relationships. Communication } \\
\text { between women and men is characterised by different } \\
\text { communication norms and different communication usage } \\
\text { principles, and these differences can hamper mutual } \\
\text { understanding. } \\
\text { In a conversation, women are characterised by cheerful } \\
\text { voice intonations and by asking questions requiring } \\
\text { confirmation (is not it? yes?), emphases (e.g., such, much) } \\
\text { and very polite constructions of a sentence (e.g., would } \\
\text { you, please, close the door). Women, during a conversation, } \\
\text { can stay within the same conversation topic for a long time. } \\
\text { The theory reveals that men and women unconsciously } \\
\text { communicate in different ways. The theory contributes to } \\
\text { communication competences, as we have to understand and } \\
\text { appreciate the communication of both genders because it } \\
\text { can become more effective and appropriate, and we have to } \\
\text { learn to adapt to the styles of both genders. }\end{array}$ \\
\hline &
\end{tabular}


Continuation of the Table 3

\begin{tabular}{|c|c|c|}
\hline No & Theories & Key ideas \\
\hline 2 & $\begin{array}{l}\text { Muted group } \\
\text { theory } \\
\text { (Kramarae, } \\
\text { 1996a; } \\
\text { Kramarae } \\
\text { 1996b; } \\
\text { Ardener, } \\
\text { Ardener, } \\
\text { 2005) }\end{array}$ & $\begin{array}{l}\text { This theory asserts that individuals with smaller influence are } \\
\text { difficult to perceive by others (cooperation partners, managers } \\
\text { and subordinates); consequently, they are forgotten, their ideas } \\
\text { and activity are silenced and they are made unobvious. The } \\
\text { theory revealed why some social groups are excluded from } \\
\text { communication: } \\
\text { - owing to gender; } \\
\text { - men are more active than women; } \\
\text { - muted status is perceived as a lower status in society; } \\
\text { is usually taken into consideration. } \\
\text { The theory says that the perception of women is regarded by } \\
\text { the public as less competent and less effective. It is important } \\
\text { that women and men become equal partners in terms of } \\
\text { formation and usage of their language. If their languages } \\
\text { become equal, their power will also equalise. }\end{array}$ \\
\hline 3 & $\begin{array}{l}\text { Interactive } \\
\text { universalism } \\
\text { theory } \\
\text { (Benhabib, } \\
\text { 1992) }\end{array}$ & $\begin{array}{l}\text { The theory suggests a new communication ethic based on the } \\
\text { concept of universal interaction among individuals. } \\
\text { S.Benhabib's purpose was to extend the social norms so that } \\
\text { they fit everyone. Communicative ethics mean that all people } \\
\text { are responsible for the voices that are not heard and have to } \\
\text { understand the silenced voices. From the feministic } \\
\text { perspective, S.Benhabib believes that a woman's ego may not } \\
\text { be divided into a public and a private ego. Women often cannot } \\
\text { afford to be autonomous due to their maternity status. The } \\
\text { author of the theory demands respect for everyone and pursue } \\
\text { possibilities for discussion on any matter. }\end{array}$ \\
\hline 4 & $\begin{array}{l}\text { Standpoint } \\
\text { theory } \\
\text { (Harding, } \\
\text { Wood, 2014) }\end{array}$ & $\begin{array}{l}\text { The theory views the world from a very feministic } \\
\text { perspective. The theory's developers and researchers are } \\
\text { Sandra Harding and Julia T. Wood who assert one of the best } \\
\text { ways to understand how our society functions is to examine } \\
\text { the opinions of those groups that are less privileged - mostly } \\
\text { women. Women in various countries (especially in the USA) } \\
\text { face much more unjust situations owing to the gender. For } \\
\text { instance, they often face prejudices at the job, as there are } \\
\text { stereotypes that women are emotional and cannot adequately } \\
\text { react on stressful situations at the job. Standpoint theory shows } \\
\text { that there has to be a possibility to see the world from the } \\
\text { perspective of excluded social groups in order to reveal and } \\
\text { understand how the world functions (Harding, Wood, 2014). }\end{array}$ \\
\hline
\end{tabular}

Source: author's construction

Communication skills relate to every individual's individual career too and are an important indicator of social competences, which are appreciated by the whole society, as the inability to be a good communication partner is often an obstacle to an individual's career growth. 
Based on previous research studies and using the findings of gender communication theories (Table 3), the author has made a summary of the dimensions of the principle of gender conformity Figure 1).

\begin{tabular}{|c|c|}
\hline $\begin{array}{l}\text { Legal provisions - } \\
\text { equality set in law }\end{array}$ & Stereotypes existing in society \\
\hline $\begin{array}{l}\text { - equality between women and men, } \\
\text { economic independence; } \\
\text { - equal pay for equal work; } \\
\text { - } \text { equality in decision-making; } \\
\text { - } \text { termect; } \\
\text { violence; } \\
\text { - promotion of gender equality outside } \\
\text { the European Union. }\end{array}$ & $\begin{array}{l}\text { - historically accepted female and } \\
\text { male professions; } \\
\text { - stereotypes about one or the other } \\
\text { gender's: } \\
\text { - role, } \\
\text { - behaviour, } \\
\text { - external appearance, } \\
\text { - mental abilities. }\end{array}$ \\
\hline Reality & Problems \\
\hline $\begin{array}{l}\text { Gender equality index: work, money, } \\
\text { knowledge, time, power and health. The } \\
\text { average gender equality index: } \\
\text { - EU }-54 \\
\text { - Latvia }-44.4 \\
\text { - Estonia }-50 \\
\text { - Lithuania }-43.6\end{array}$ & $\begin{array}{l}\text { - gender disproportion of } \\
\text { pedagogues; } \\
\text { - limited opportunities for women to } \\
\text { occupy various job positions; } \\
\text { limited opportunities for women to } \\
\text { occupy a job position due to their } \\
\text { age. }\end{array}$ \\
\hline \multicolumn{2}{|c|}{$\begin{array}{l}\text { Actions } \\
\text { Proposals how to tackle gender inequality problems: }\end{array}$} \\
\hline $\begin{array}{l}\text { - } \quad \text { promotion of gender equality stipul } \\
\text { application of communication theor } \\
\text { - gender communication styles; } \\
\text { - Interactive universalism theory } \\
\text { - Muted group theory; } \\
\text { - influence of the androcentrism } \\
\text { - Standpoint theory; } \\
\text { - breaking down stereotypes; } \\
\text { - } \quad \text { raising self-confidence in women. }\end{array}$ & $\begin{array}{l}\text { lated in laws; } \\
\text { ries: } \\
\text { n; } \\
\text { n of society on the choice of a profession; }\end{array}$ \\
\hline $\begin{array}{r}\text { Res } \\
\text { equality between }\end{array}$ & $\begin{array}{l}\text { ult } \\
\text { women and men }\end{array}$ \\
\hline
\end{tabular}

Fig. 1. Dimensions of the principle of gender conformity

Source: author's construction 
It comprises both legal provisions, the public's stereotypes on the differences between women and men and proposals for tackling gender equality problems. The proposals stress the necessity for promoting the observance of gender equality stipulated in the law and the use of communication theories and for breaking down stereotypes and raising self-confidence in women.

The principle of gender conformity in career counselling for women expresses associations between the factors influencing women's careers and situations causing a professional crisis as well as involves dimensions of this principle and criteria for identifying a professional crisis. The observance of the principle of gender conformity in career counselling contributes to the career development of women being in professional crisis situations. The author has summarised the criteria derived from the dimensions of the principle of gender conformity (Figure 2).

\begin{tabular}{|r|l|}
\hline No & \multicolumn{1}{|c|}{ Criteria } \\
\hline 1 & the "glass ceiling" is present in women's careers (Ķikule, 2006) \\
\hline 2 & $\begin{array}{l}\text { there are stereotypes on women's and men's professions (Strategy for equality } \\
\text { between women and men 2010-2015, 2010) }\end{array}$ \\
\hline 3 & $\begin{array}{l}\text { equal wages are paid for the same work regardless of gender (Strategy for equality } \\
\text { between women and men 2010-2015, 2010) }\end{array}$ \\
\hline 4 & for women, communication in a team is different (according to D. Tannen) \\
\hline 5 & $\begin{array}{l}\text { during the course of conversation, women easily change the rules of game } \\
\text { (according to D. Tannen) }\end{array}$ \\
\hline 6 & $\begin{array}{l}\text { for women, cooperation and the course of a conversation itself are important } \\
\text { (according to D. Tannen) }\end{array}$ \\
\hline 7 & $\begin{array}{l}\text { in order to cooperate, women use conversation to express their interest in other } \\
\text { individuals and their needs (according to Tannen) }\end{array}$ \\
\hline 8 & women's world perception is based on care and responsibility (D. Tannen) \\
\hline 9 & $\begin{array}{l}\text { communication between men and women is characterised by the communication } \\
\text { norms and different language usage principles, and these differences can obstruct } \\
\text { their understandings (according to D. Tannen) }\end{array}$ \\
\hline 10 & $\begin{array}{l}\text { in a conversation, women are characterised by cheerful voice intonations and by asking } \\
\text { questions requiring confirmation (is not it? Yes?), emphases (e.g., such, much) and very } \\
\text { polite constructions of a sentence (e.g., would you, please) (according to Tannen) }\end{array}$ \\
\hline 11 & $\begin{array}{l}\text { during a conversation, women can stay within the same conversation topic for a } \\
\text { long time (according to D. Tannen) }\end{array}$ \\
\hline 12 & $\begin{array}{l}\text { women being quiet are excluded from communication at their job and their career } \\
\text { growth opportunities in their team are limited (according to K. Kramarae) }\end{array}$ \\
\hline 13 & $\begin{array}{l}\text { women having a family and children have limited choices of a career (according } \\
\text { to K. Kramarae) }\end{array}$ \\
\hline 14 & $\begin{array}{l}\text { women are "emotional" and cannot adequately act in a stressful situation at their } \\
\text { job (according to S. Benhabib) }\end{array}$ \\
\hline
\end{tabular}

Fig. 2. Criteria for identifying the effects of observing the principle of gender conformity on women's careers

Source: author's construction 
The first three criteria were taken from professional constraint theory. The glass ceiling in women's careers means vertical labour market segregation, which refers to the tendency of women and men to take different job positions in the same profession group as well as the barriers to vertical career growth. Criteria 4-11 were taken from D. Tannen's Gender communication theory (Tannen, 1990/2007; Tannen, 1992a; Tannen, 1992b). Criteria 12 and 13 were taken from K. Kramarae's Muted group theory (Kramarae, 1996a; 1996b; Ardener, Ardener, 2005). Criterion 14 was taken from S. Benhabib's Interactive universalism theory (Benhabib, 1992).

The criteria are used in further research on the effects of the principle of gender conformity on women's careers.

Chapter 3 is entitled Developmental experiment on coping with a professional crisis for women. It deals with a career counselling methodology for women in professional crisis situations, which was developed by the author as well as evaluated by experts, and the professional crisis management model, which was developed and scientifically justified by the author, describes empirical studies on career change by women in Latvia and Lithuania and the developmental experiment and analyses the factors influencing women's careers and the skills contributing to career development. The chapter is comprised of three subchapters.

Subchapter 3.1. The subchapter is entitled Organising surveys and their characteristics.

The author began conducting surveys by using social networks such as draugiem.lv, facebook.lv and twitter.com and requesting women to fill in survey questionnaires at the Jelgava, Bauska and Dobele Regional Departments of the State Employment Agency, the Zemgale Regional Department of the State Police as well as by talking in person to women and sending questionnaires via e-mail to women living in Latvia and Lithuania. The respondents were selected randomly. The sample populations were non-probable and formed spontaneously. The principles of purposefulness and availability were employed in each survey. The surveys involved 1087 women, 48 career counsellors and 4 experts; the developmental experiment involved 18 women.

A survey scheme is presented in Figure 3. 


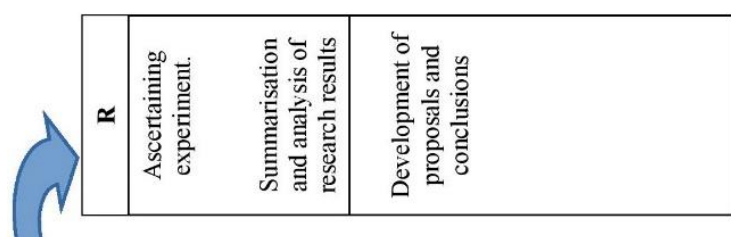

눙

눙

造.

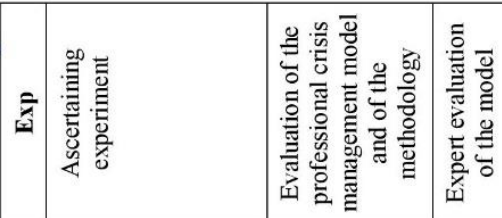

$\sum \dot{0}$

ํㅇ응

ฮ) อ

夏

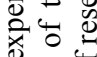

of

㔽高

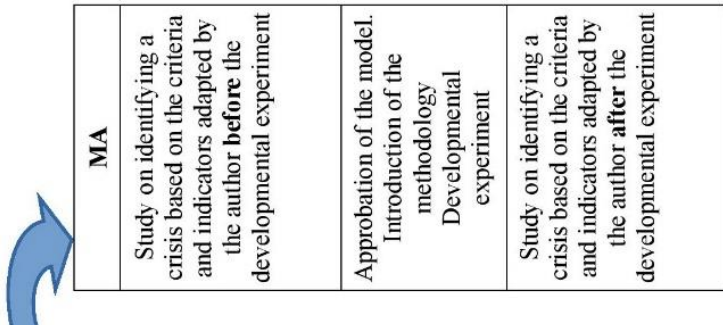

흉

ठู సี

तี त्रे

एँ

등.

플

क्ष

E

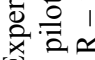

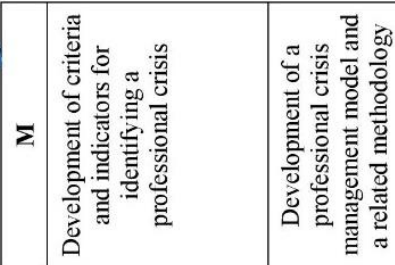

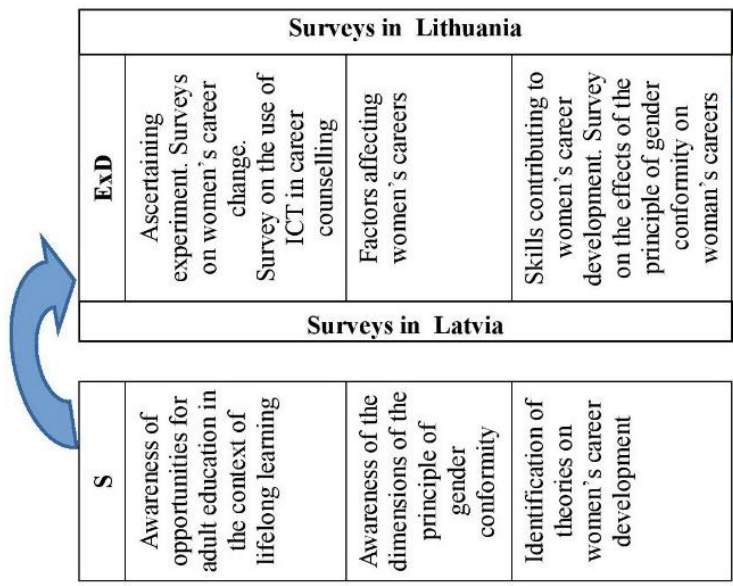

I $匚$

总总

记

成

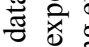

䒿 完.

을 을

$=\overline{0}$

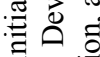

41 告

电西

突茄苛.

를

त文

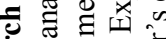

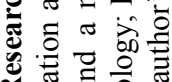

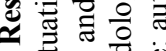

的动

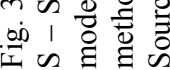


Subchapter 3.2. The subchapter is entitled Development of a model and a methodology for professional crisis management. It comprises 8 subchapters.

Subchapter 3.2.1 is entitled Results of a survey on career change by women. It summarises statistical data on the women who participated in a survey and analyses the survey results.

The survey was conducted from 1 June to 18 August 2015, sending 2000 questionnaires to women via e-mail in Latvia and Lithuania as well as surveying them in person. Of the sent questionnaires, 1087 valid questionnaires were received back: 909 from the women living in Latvia and 178 from Lithuania. The women were surveyed both via e-mail and via social networks: www.draugiem.lv, twitter.com, facebook.com. The questionnaire was designed using questionnaire matrixes available on the website www.visidati.lv in order that respondents could fill in their questionnaires in an easy and comfortable way. The data were processed employing the grouping method, the descriptive statistics method, MS Excel and SPSS (Paura, Arhipova, 2002)

In the beginning of the survey, the respondents were asked a question about how much would they be ready to change their job or occupation and requested to rate it on a scale from 1 to 5 , where 1 meant "at present" respondents were not ready to change their job and 5 meant that they needed to change their jobs or occupations very much. Of the respondents, $42 \%$ said they were not ready to change their jobs, while $10 \%$ had decided to change their jobs.

The survey ascertained whether the respondents characterised their situation as a crisis (a dangerous, complicated and tough situation). Yes replies were given by $29 \%$, no replies by $72 \%$.

One can conclude that $29 \%$ of the women, however, felt to be in a crisis situation and they needed assistance to overcome a professional crisis. The assistance could be offered by means of the professional crisis management model (Figure 4).

Subchapter 3.2.2 is entitled Factors influencing women's' careers. It examines the factors influencing the choice of careers by women and ascertains and analyses the factors influencing women's' careers in the respondents' opinion.

To identify the most essential factors in women's choice of a profession in the respondents' opinion, the respondents were asked to rank the given factors by importance. There were five reply options beginning with " 1 " - no influence through to "5" meaning great influence. The reply option "great influence" was selected for analysis. It is necessary to examine the distribution of respondent replies and identify whether the replies are consistent with the theoretical distribution of observations (Table 4). 
Factors influencing women's successful careers

Data acquired from 1 June to 18 August 2015 in an anonymous survey of women, $\mathrm{n}=1087$.

\begin{tabular}{|c|c|c|c|c|}
\hline No & Factors & $\begin{array}{l}\text { Empirical } \\
\text { number } \\
\text { of replies }\end{array}$ & $\begin{array}{l}\text { Theoretical } \\
\text { number of } \\
\text { replies }\end{array}$ & $\begin{array}{c}\text { Difference } \\
\text { between } \\
\text { theoretical and } \\
\text { empirical } \\
\text { numbers } \\
\end{array}$ \\
\hline 1. & Age & 297 & 268.3 & 28.7 \\
\hline 2. & Gender & 94 & 268.3 & -174.3 \\
\hline 3. & $\begin{array}{l}\text { Family status (married, } \\
\text { unmarried) }\end{array}$ & 111 & 268.3 & -157.3 \\
\hline 4. & $\begin{array}{l}\text { Experience of your family } \\
\text { (parent's experience in their } \\
\text { profession) }\end{array}$ & 82 & 268.3 & -186.3 \\
\hline 5. & Children (yes, no, number) & 215 & 268.3 & -53.3 \\
\hline 6. & Education level & 558 & 268.3 & 289.7 \\
\hline 7. & Place of residence & 259 & 268.3 & -9.3 \\
\hline 8. & Financial situation & 198 & 268.3 & -70.3 \\
\hline 9. & $\begin{array}{l}\text { Number of jobs in your } \\
\text { place of residence }\end{array}$ & 443 & 268.3 & 174.7 \\
\hline 10. & Physical capacities & 152 & 268.3 & -116.3 \\
\hline 11. & Lifestyle & 161 & 268.3 & -107.3 \\
\hline 12. & Attitude of your supervisors & 438 & 268.3 & 169.7 \\
\hline 13. & Psychological climate & 439 & 268.3 & 170.7 \\
\hline 14. & $\begin{array}{l}\text { Distance from home to the } \\
\text { workplace }\end{array}$ & 236 & 268.3 & -32.3 \\
\hline 15. & Partner support & 341 & 268.3 & 72.7 \\
\hline \multicolumn{5}{|c|}{$\chi^{2}$ test results } \\
\hline \multicolumn{2}{|c|}{ Indicator } & \multicolumn{3}{|c|}{ Replies } \\
\hline \multicolumn{2}{|c|}{$\chi^{2}$ real value } & \multicolumn{3}{|c|}{1126.770} \\
\hline \multicolumn{2}{|c|}{ Number of degrees of freedom } & \multicolumn{3}{|c|}{14} \\
\hline \multicolumn{2}{|c|}{$\mathrm{p}$-value } & \multicolumn{3}{|c|}{0.000} \\
\hline
\end{tabular}

Conclusion. Since the p-value $=0.000<0.05$, one can conclude with a $95 \%$ probability that the numbers of respondent replies are different and the distribution of the respondent replies is quite uneven (Paura, Arhipova, 2002). Based on a $\chi^{2}$ test, one can observe a significant prevalence of the number of replies for Factor 6 "Education level". This means that most of the women surveyed mentioned the education level as the most important factor. The number of vacant jobs in the place of residence was ranked second, the psychological 
climate was ranked third, the attitude of supervisors was ranked fourth and partner support held fifth position.

The diversity of professions is very broad. To choose an appropriate and desirable profession, first of all, it is necessary to examine oneself - what personal qualities are possessed and what qualities have to be built up - as well as the description of the desired profession and to identify whether the profession matches the wishes. Accordingly, the author included in her survey a question about personal qualities. The respondents were asked to indicate which of the given personal qualities influenced women's successful career development. There were five reply options beginning with " 1 " - no influence through to "5" - great influence. The reply option "great influence" was selected for analysis. It is necessary to examine the distribution of respondent replies and identify whether the replies match the theoretical distribution of observations (Table 5).

Table 5

Rankings of personal qualities by importance

Data acquired from 1 June to 18 August 2015 in an anonymous survey of women, $\mathrm{n}=1087$.

\begin{tabular}{|r|l|c|c|c|}
\hline No & Personal qualities & $\begin{array}{c}\text { Empirical } \\
\text { number of } \\
\text { replies }\end{array}$ & $\begin{array}{c}\text { Theoretical } \\
\text { number of } \\
\text { replies }\end{array}$ & $\begin{array}{c}\text { Difference between } \\
\text { theoretical and } \\
\text { empirical numbers }\end{array}$ \\
\hline 1 & Wish to help others & 131 & 407.7 & -276.7 \\
\hline 2 & Patience & 376 & 407.7 & -31.7 \\
\hline $\mathbf{3}$ & Enterprise & $\mathbf{7 2 6}$ & 407.7 & $\mathbf{3 1 8 . 3}$ \\
\hline 4 & Sensitivity & 153 & 407.7 & -254.7 \\
\hline $\mathbf{5}$ & Persistence & $\mathbf{6 7 7}$ & $\mathbf{4 0 7 . 7}$ & $\mathbf{2 6 9 . 3}$ \\
\hline $\mathbf{6}$ & Purposefulness & $\mathbf{7 2 8}$ & $\mathbf{4 0 7 . 7}$ & $\mathbf{3 2 0 . 3}$ \\
\hline 7 & $\begin{array}{l}\text { Ability to keep } \\
\text { secrets }\end{array}$ & 305 & 407.7 & -102.7 \\
\hline $\mathbf{8}$ & $\begin{array}{l}\text { Ability to cope with } \\
\text { stress }\end{array}$ & $\mathbf{6 2 1}$ & $\mathbf{4 0 7 . 7}$ & $\mathbf{2 1 3 . 3}$ \\
\hline 9 & $\begin{array}{l}\text { Thirst for } \\
\text { knowledge }\end{array}$ & 337 & 407.7 & -70.7 \\
\hline 10 & Reliability & 507 & 407.7 & 99.3 \\
\hline 11 & Sincerity & 130 & 407.7 & -277.7 \\
\hline 12 & Skilfulness & 435 & 407.7 & 27.3 \\
\hline 13 & Empathy & 175 & 407.7 & -232.7 \\
\hline 14 & Talkativeness & 181 & 407.7 & -226.7 \\
\hline 15 & $\begin{array}{l}\text { Ability to control } \\
\text { oneself }\end{array}$ & 512 & 407.7 & 104.3 \\
\hline 16 & Determination & 570 & 407.7 & 162.3 \\
\hline
\end{tabular}


Continuation of the Table 5

\begin{tabular}{|c|c|c|c|c|}
\hline No & Personal qualities & $\begin{array}{c}\text { Empirical } \\
\text { number of } \\
\text { replies }\end{array}$ & $\begin{array}{c}\text { Theoretical } \\
\text { number of } \\
\text { replies }\end{array}$ & $\begin{array}{l}\text { Difference between } \\
\text { theoretical and } \\
\text { empirical numbers }\end{array}$ \\
\hline 17 & Creativity & 415 & 407.7 & 7.3 \\
\hline 18 & Self-confidence & 566 & 407.7 & 158.3 \\
\hline 19 & Logical thinking & 619 & 407.7 & 211.3 \\
\hline 20 & Diligence & 435 & 407.7 & 27.3 \\
\hline 21 & Loyalty & 394 & 407.7 & -13.7 \\
\hline 22 & Sense of duty & 533 & 407.7 & 125.3 \\
\hline 23 & Courageousness & 404 & 407.7 & -3.7 \\
\hline 24 & Tactfulness & 375 & 407.7 & -32.7 \\
\hline 25 & Tolerance & 209 & 407.7 & -198.7 \\
\hline 26 & Accuracy & 335 & 407.7 & -72.7 \\
\hline 27 & Honesty & 408 & 407.7 & .3 \\
\hline 28 & Politeness & 323 & 407.7 & -84.7 \\
\hline 29 & Sense of humour & 195 & 407.7 & -212.7 \\
\hline 30 & $\begin{array}{l}\text { Good observation } \\
\text { ability }\end{array}$ & 352 & 407.7 & -55.7 \\
\hline 31 & Order and tidiness & 277 & 407.7 & -130.7 \\
\hline 32 & Insistence & 528 & 407.7 & 120.3 \\
\hline 33 & Discipline & 522 & 407.7 & 114.3 \\
\hline \multicolumn{5}{|c|}{$\chi^{2}$ test results } \\
\hline & Indicators & \multicolumn{3}{|c|}{ Replies } \\
\hline & $\chi^{2}$ real value & \multicolumn{3}{|c|}{2312.445} \\
\hline & $\begin{array}{r}\text { Number of degrees of } \\
\text { freedom }\end{array}$ & \multicolumn{3}{|c|}{32} \\
\hline & $\mathrm{p}$-value & \multicolumn{3}{|c|}{0.000} \\
\hline
\end{tabular}

Conclusion. Since the $p$-value $=0.000<0.05$, one can conclude with a $95 \%$ probability that the numbers of respondent replies are different and the distribution of respondent replies is uneven. Based on a $\chi^{2}$ test, one can observe a significant prevalence of the number of replies for Quality 6 "Purposefulness" and Quality 3 "Enterprise". It means that most of the women surveyed mentioned purposefulness as the most important personal quality, followed by enterprise in second position, persistence in third position, ability to cope with stress in fourth position and logical thinking in fifth position. So, personal qualities are an important aspect of successful career development. 
Subchapter 3.2.3 is entitled Skills contributing to women's career development. It examines the skills that promote women's career development in the respondents'opinion.

The respondents were asked to indicate which of the given personal qualities influenced women's successful career development. There were five reply options beginning with " 1 " - no influence through to " 5 " meaning great influence. The reply option "great influence" was selected for analysis. It is necessary to examine the distribution of respondent replies and identify whether the replies match the theoretical distribution of observations (Table 6)

Table 6

Woman's rankings of the most important skills needed for the successful development of women's careers

Data acquired from 1 June to 18 August 2015 in an anonymous survey of

\begin{tabular}{|c|l|c|c|c|}
\hline No & \multicolumn{1}{|c|}{ Skills } & $\begin{array}{c}\text { Empirical } \\
\text { number } \\
\text { of replies }\end{array}$ & $\begin{array}{c}\text { Theoretical } \\
\text { number of } \\
\text { replies }\end{array}$ & $\begin{array}{c}\text { Difference } \\
\text { between } \\
\text { theoretical } \\
\text { and empirical } \\
\text { numbers }\end{array}$ \\
\hline $\mathbf{1}$ & $\begin{array}{l}\text { Cooperate with other } \\
\text { individuals }\end{array}$ & $\mathbf{6 3 1}$ & $\mathbf{5 3 6 . 7}$ & $\mathbf{9 4 . 3}$ \\
\hline $\mathbf{2}$ & Tackle problematic situations & $\mathbf{6 4 4}$ & $\mathbf{5 3 6 . 7}$ & $\mathbf{1 0 7 . 3}$ \\
\hline 3 & Listen to other individuals & 420 & 536.7 & -116.7 \\
\hline 4 & $\begin{array}{l}\text { Convince others about my } \\
\text { opinion }\end{array}$ & 470 & 536.7 & -66.7 \\
\hline 5 & $\begin{array}{l}\text { Use body language and the } \\
\text { language of gestures }\end{array}$ & 150 & 536.7 & -386.7 \\
\hline 6 & Assume responsibility & 599 & 536.7 & 62.3 \\
\hline 7 & Execute the work task precisely & 583 & 536.7 & 46.3 \\
\hline $\mathbf{8}$ & Organise one's own work & $\mathbf{7 0 2}$ & $\mathbf{5 3 6 . 7}$ & $\mathbf{1 6 5 . 3}$ \\
\hline 9 & Find a solution to a problem & 635 & 536.7 & 98.3 \\
\hline 10 & Act in changing situations & 524 & 536.7 & -12.7 \\
\hline $\mathbf{1 1}$ & Make decisions independently & $\mathbf{6 4 6}$ & $\mathbf{5 3 6 . 7}$ & $\mathbf{1 0 9 . 3}$ \\
\hline 12 & Lead other individuals & 468 & 536.7 & -68.7 \\
\hline 13 & $\begin{array}{l}\text { Develop one's own career } \\
\text { purposefully }\end{array}$ & 509 & 536.7 & -27.7 \\
\hline 14 & $\begin{array}{l}\text { Use a computer for work with } \\
\text { texts }\end{array}$ & 509 & 536.7 & -27.7 \\
\hline 15 & $\begin{array}{l}\text { Use a computer for work with } \\
\text { numerical information }\end{array}$ & 464 & 536.7 & $-72,7$ \\
\hline & \multicolumn{2}{|c|}{$\mathrm{n}$} & \\
\hline
\end{tabular}


Continuation of the Table 6

\begin{tabular}{|c|c|c|c|c|}
\hline No & Skills & $\begin{array}{c}\text { Empirical } \\
\text { number } \\
\text { of replies }\end{array}$ & $\begin{array}{c}\text { Theoretical } \\
\text { number of } \\
\text { replies }\end{array}$ & $\begin{array}{c}\text { Difference } \\
\text { between } \\
\text { theoretical } \\
\text { and empirical } \\
\text { numbers }\end{array}$ \\
\hline 16 & $\begin{array}{l}\text { Use a computer for information } \\
\text { search }\end{array}$ & 540 & 536.7 & 3.3 \\
\hline 17 & $\begin{array}{l}\text { Use a computer for } \\
\text { communication }\end{array}$ & 437 & 536.7 & -99.7 \\
\hline 18 & $\begin{array}{l}\text { Knowledge of foreign } \\
\text { languages }\end{array}$ & 550 & 536.7 & 13.3 \\
\hline 19 & Presentation skills & 553 & 536.7 & 16.3 \\
\hline 20 & Basic skills in management & 565 & 536.7 & 28.3 \\
\hline 21 & Leadership & 520 & 536.7 & -16.7 \\
\hline 22 & Ability to work in a team & 689 & 536.7 & 152.3 \\
\hline \multicolumn{5}{|c|}{$\chi^{2}$ test results } \\
\hline & Indicators & \multicolumn{3}{|c|}{ Replies } \\
\hline & $\chi^{2}$ real value & \multicolumn{3}{|r|}{539.079} \\
\hline \multicolumn{2}{|r|}{ Number of degrees of freedom } & \multicolumn{3}{|r|}{21} \\
\hline \multicolumn{2}{|r|}{ p-value } & \multicolumn{3}{|r|}{0.000} \\
\hline
\end{tabular}

Conclusion. Since the p-value $=0.000<0.05$, one can conclude with a $95 \%$ probability that the numbers of respondent replies are very different and the distribution of respondent replies is quite uneven. Based on a $\chi^{2}$ test, one can observe a significant prevalence of the number of replies for Skill 8 "Organise one's own work" and Skill 22 "Ability to work in a team". It means that most of the women surveyed mentioned the skill to organise their own work as their most important skill, followed by ability to work in a team in second position, making decisions independently in third position, tackling problematic situations in fourth position and cooperating with other individuals in fifth position.

Subchapter 3.2.4 is entitled Survey on Identifying a professional crisis according to criteria and indicators.

The survey on career change, which was conducted from 1 June to 18 August 2015, involved 1087 women. The survey's third part "Professional crisis survey questionnaire" included a question on whether a respondent considered her current situation a professional crisis. If the respondent replied "yes", other questions regarding the indicators and criteria for identifying a professional crisis had to be answered. If a reply was "no", the respondent had to answer a question of the next part. The survey revealed that $29 \%$ (310) women admitted they were in a crisis situation. 
The survey on identifying a professional crisis according to the criteria and indicators was continued with the $310(29 \%)$ women who admitted being in a professional crisis situation. Based on the theoretical analysis of professional crisis situations made in Subchapter 2.2, the author adapted the criteria and indicators for identifying a professional crisis that were based on the theoretical findings made by E.F. Zeer and E.E. Simanyuk. By means of the criteria and indicators, women can self-assess their crisis situations (see Table 2) before taking a counselling session. A repeated identification of the crisis according to the criteria and indicators is done after completing the activities prescribed by the model. Analysing the survey's part "Professional crisis survey questionnaire" the author counted up the respondents' replies: 1 - fully disagree; 2 - disagree; 3 - neutral; 4 - agree; and 5 - fully agree. The author added the number of replies "agree" and the number of replies "fully agree" together and did the same with the replies "fully disagree" and "disagree".

After analysing the respondents' replies based on the criteria and indicators developed for identifying a professional crisis and adding the replies "agree" and "fully agree" together, one can find that $60 \%$ of the respondents were satisfied with their professional education, $65 \%$ were satisfied with their professional preparedness; yet, a large number of the respondents, in their selfassessments, showed dissatisfaction: $57 \%$ were dissatisfied with their opportunities to self-realise themselves in the existing professional situation; $46 \%$ were dissatisfied with their socio-professional status, $48 \%$ felt psychophysiological changes and health deterioration in themselves and $26 \%$ admitted they had professional deformations, which indicated the existence of a crisis situation.

Since a relatively large number of the respondents admitted their dissatisfaction with their professional activity, which evidenced a crisis situation, it indicated the need for career guidance suggested by the author in her professional crisis management model.

Subchapter 3.2.5 is entitled Effects of the principle of gender conformity on women's careers, and it summarises and analyses two surveys on this topic.

The first survey on the principle of gender conformity regarding women's careers was conducted from December 2014 to January 2015 and involved career counsellors; its purpose was to get insight into the effects of the principle of gender conformity on women's careers. The survey involved 48 career counsellors. It employed the criteria for identifying the effects of the principle of gender conformity on women's careers that were developed in Subchapter 2.3 (see Figure 2). The survey results revealed that the most career counsellors surveyed agreed with the following assertions:

- women use conversation to express their interest in other individuals and their needs in order to cooperate $(85 \%)$;

- for women, cooperation and the course of a conversation itself are important (83\%); 
- for women, communication in a team is different (79\%);

- there are stereotypes on women's and men's professions (79\%);

- women's world perception is based on care and responsibility $(73 \%)$.

The most career counsellors did not agree with the following assertions:

- women are "emotional" and cannot adequately act in a stressful situation at their job (81\%);

- the "glass ceiling" is present in women's careers (73\%);

- equal wages are paid for the same work regardless of gender (56\%).

The second survey on the principle of gender conformity regarding women's careers was conducted from 1 June to 18 August 2015, in which 1087 women participated, and the author summarised their replies.

An analysis of the results for the survey's part "Questionnaire for identifying the effects of the principle of gender conformity on women's careers" revealed that $85 \%$ of the respondents admitted that there were stereotypes on women's and men's professions, $80 \%$ pointed out that for women, communication in a team was different and $58 \%$ mentioned that the ways of woman's and man's communication are characterised by different social interaction norms and different language use principles and the mentioned differences can hinder them from understanding each other. Of the respondents, $64 \%$ confirmed that those women who were silent were excluded from communication at their jobs and career growth opportunities in a team were limited; $53 \%$ pointed out that the women who had families and children were limited regarding their choice of a career. Slightly less than a half, $49 \%$, admitted that the "glass ceiling" existed.

To examine the effects of the principle of gender conformity on women's careers, the survey's part "Questionnaire for identifying the effects of the principle of gender conformity on women's careers" included questions on what influenced solutions to women's career development problems. The respondents' replies are summarised in Table 7. 
Percentage distribution of the respondents' replies to the question on observing the principle of gender conformity in career guidance for women

\begin{tabular}{|l|c|c|c|c|c|c|}
\hline $\begin{array}{c}\text { How does the } \\
\text { observance of } \\
\text { the principle } \\
\text { of gender } \\
\text { conformity } \\
\text { influence } \\
\text { solutions to } \\
\text { women's } \\
\text { career } \\
\text { development } \\
\text { problems? }\end{array}$ & $\begin{array}{c}\mathbf{1} \\
\text { no } \\
\text { influence } \\
\text { at all }\end{array}$ & $\begin{array}{c}\mathbf{2} \\
\text { no } \\
\text { influence }\end{array}$ & $\begin{array}{c}\mathbf{3} \\
\text { neutral }\end{array}$ & $\begin{array}{c}\text { Respondents' ratings } \\
\text { influences } \\
\text { insignificantly }\end{array}$ & $\begin{array}{c}\text { Total } \\
\text { (\%) }\end{array}$ \\
\hline $\begin{array}{c}\text { Application of } \\
\text { influences } \\
\text { significantly }\end{array}$ & 4 & 7 & 39 & 33 & 17 & 100 \\
theories & 4 & 5 & 36 & 36 & 21 & 100 \\
\hline $\begin{array}{l}\text { Breaking down } \\
\text { stereotypes }\end{array}$ & 2 & 2 & 24 & 36 & 35 & 100 \\
\hline $\begin{array}{l}\text { Raising self- } \\
\text { confidence in } \\
\text { women }\end{array}$ & 2 & 3 & & & & 100 \\
\hline $\begin{array}{l}\text { Observance of } \\
\text { gender equality }\end{array}$ & 2 & 4 & 28 & 31 & 35 & 100 \\
\hline
\end{tabular}

The principle of gender conformity, which was suggested and theoretically justified by the author and which is recommended for career counselling for women in professional crisis situations, involves the following dimensions: gender equality stipulated in laws, stereotypes existing in the society, the gender equality index, recommendations for action to make solutions to gender inequality problems - to promote gender equality stipulated in laws, to apply communication theories in communication between women and men and in counselling, to eliminate stereotypes and to raise women's self-confidence. After analysing the survey results and adding the replies "influences insignificantly" and "influences significantly" together, one can find that the respondents considered applying communication theories (50\%), eliminating stereotypes (57\%), raising women's self-confidence (71\%) and observing gender equality $(66 \%)$ to be necessary activities for career guidance (Table 7).

A $\chi^{2}$ test revealed that the replies "raising self-confidence in women" and "observance of gender equality" were statistically significant. This means that 
the respondents believed that observing the principle of gender conformity very considerably influenced women's self-confidence and the observance of gender equality. Accordingly, observing the principle of gender conformity significantly affected solutions to women's career development problems.

Subchapter 3.2.6 is entitled Discussion on career change by women; it summarises the findings of scientists regarding women's career development and career change by women.

In recent years in the world, particularly in Europe and Latvia too, lifelong education has become a topical term. In Latvia, lifelong education has been little researched in its various aspects. Besides, it has been little researched particularly with respect to its role in and effects on women's careers in professional crisis situations; this, to some extent, is evidenced by the fact that no empirical research papers on this problem are available in Latvia.

One of the research investigations performed at LLU by D. Bite, who examined employment problems in towns, focused on women's careers in towns; she found that in towns, there was a strong association between the social environment and infrastructure and the employment situation; for this reason, purposeful career growth was possible for a limited number of professions and jobs.

American scientists and pedagogue D.R. Wetzel has researched adult education and lifelong education in the USA. He points out that lifelong education is essential today for any employee - those who work and those who seek for a job - and that it is necessary to persistently renew and build up one's working skills.

There are interesting research studies done by K. Caprino (Caprino, 2013), who is a researcher and a work and life coach in the USA, on women's professional careers. She has found that women who pursue a successful career for many years, in their mid-life years, feel that their professional life and identity do not satisfy them, i.e. do not function as planned. Her research found that the majority of women faced at least one of the implicit working and private life crises mentioned by the author, among them chronic health problems, financial dependence and the painful loss of their identity or ego.

A number of authors such as A. Crowe, M. Profita and M. Miller have focused on career change and advice on how to do it best (Crowe, 2009; Profita, 2016; Miller, 2016). American scientist E. Ostrow (Ostrow, 2012) is a life and career coach, and, at present, life and career coaching is a very popular practice in the USA. She practises and studies women's careers and career change.

After familiarising herself with the research papers and findings of foreign and national scientists, the author concludes that a new research topic has been initiated in Latvia with regard to women's careers, career change by women in professional crisis situations as well as the role of lifelong education in women's career development. 
Subchapter 3.2.7 entitled Professional crisis management model deals with a professional crisis management model for women developed and scientifically justifies by the author and gives a detailed description of the model.

Pedagogical models implement the unity of theory and practice in respect to teaching. A model in pedagogy specifies and allows predicting the learning outcomes in the pedagogical process (Žogla, 2001). Accordingly, it is very important to integrate such a model in career counselling, which involves both career education, career guidance and career research, in order to achieve expected results.

To achieve such an objective and provide assistance to women in professional crisis situations, the author developed the Professional crisis management model for women (Figure 4).

The target audience are women who wish to change their occupations or are forced to do it because of being in a professional crisis situation.

The purpose of the model is to examine the situation in a client's career development, identify the key ways how to start a career change, determine the skills and wishes, assess the potential of the future profession, offer career counselling sessions and an training programme for overcoming the professional crisis. 


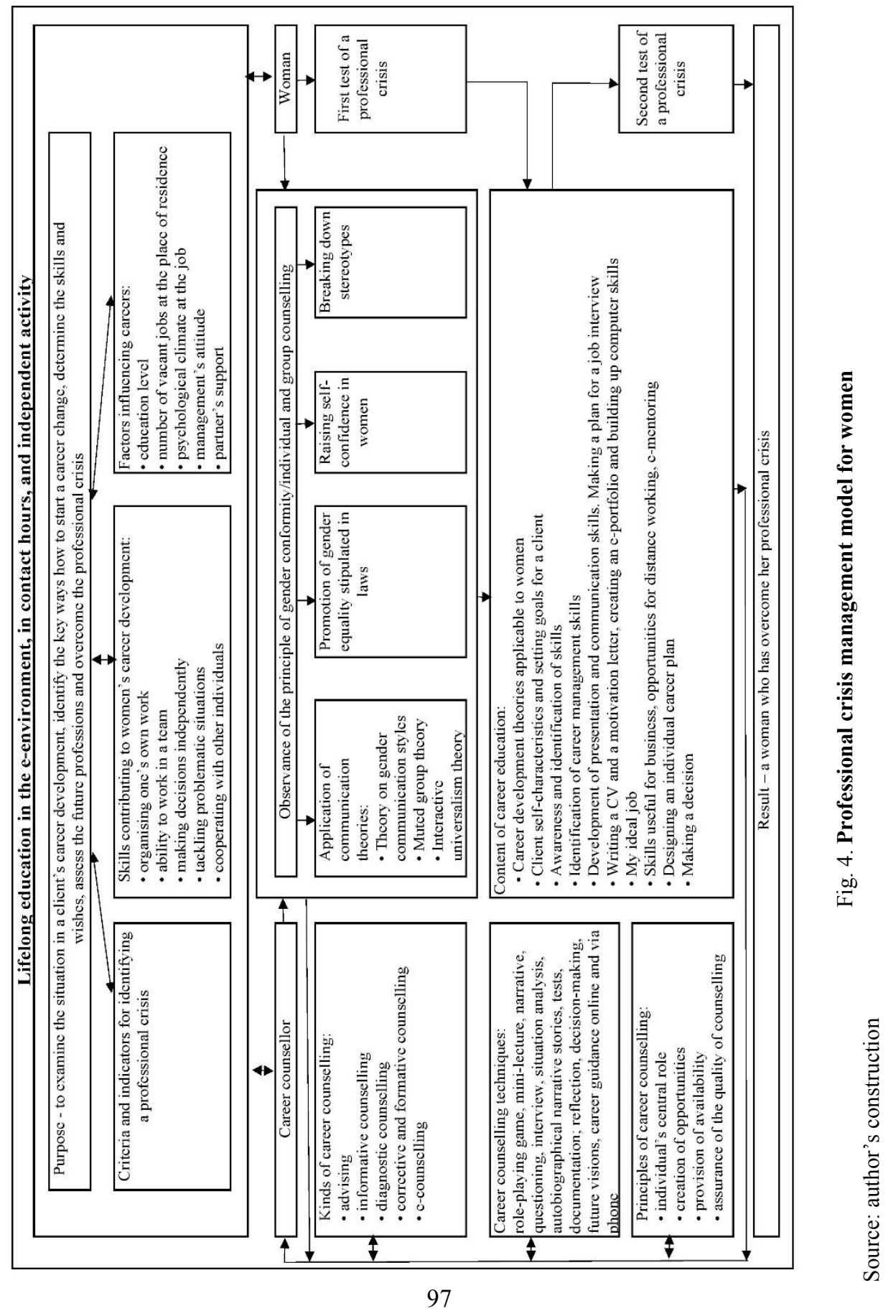


Subchapter 3.2.8 is entitled Methodology for professional crisis management. The subchapter theoretically justifies the methodology and provides a plan of classes for the Client-developing programme for career change for women in professional crisis situation. The methodology is available in the e-environment, and it gives selected examples of participant reflections and explains the role of an e-portfolio, self-employment activities, distance working opportunities, kinds of e-mentoring and activity areas for it.

The Client-developing programme for career change for women in professional crisis situations is intended to help women who need advice and assistance in a crisis situation and to provide necessary information, to promote their thinking and encourage them to analyse their surrounding environment and their situation, and to raise their self-confidence and contribute to their professional success. The programme involves $\mathbf{1 0}$ individual classes in which the counsellor gets familiarised with a client and her problems, the client does various exercises and tests and, working together, a decision is made.

The programme employs the following key career counselling techniques: role-playing games, autobiographic stories, tests, documentation; situation analysis; decision-making; feedback; future visions; and e-counselling.

A repeated test on the professional crisis is done after the client has learnt the education content suggested by the author's client-developing programme.

The final result of applying this model in career guidance for women in professional crisis situations results in a harmonious woman who has coped with her professional crisis.

A general plan of the programme's classes is summarised in Table 8, while the programme and its topics as well as its purposes and learning outcomes are available in an annex.

Table 8

Plan of classes for the Client-Developing Programme for career change for women in professional crisis situations in the e-environment

\begin{tabular}{|l|l|l|l|}
\hline No & $\begin{array}{l}\text { Topic of the } \\
\text { class }\end{array}$ & \multicolumn{1}{|c|}{ Description of the class } & $\begin{array}{l}\text { Time } \\
\text { min }\end{array}$ \\
\hline 1 & $\begin{array}{l}\text { Career } \\
\text { development } \\
\text { theories } \\
\text { applicable to } \\
\text { women }\end{array}$ & $\begin{array}{l}\text { Introductory information. A test for identifying a } \\
\text { professional crisis. } \\
\text { The counsellor gives brief insight into who gets } \\
\text { what during the classes, what rules have to be } \\
\text { obeyed and how long the classes are. } \\
\text { Career development theories applicable to women. }\end{array}$ & 45 \\
\hline 2 & $\begin{array}{l}\text { Client self- } \\
\text { characteristics } \\
\text { and setting } \\
\text { goals for the } \\
\text { client }\end{array}$ & $\begin{array}{l}\text { Discussion on the exercise "My life tree". An } \\
\text { exercise and discussion "Assessment of having/not } \\
\text { having a job". Identification of the client's } \\
\text { experience. The client's self-characteristics, the } \\
\text { identification of the client's traits. Identification of } \\
\text { the client's interests. } \\
\text { Lecture. Significance of setting goals. Discussion. }\end{array}$ & 45 \\
\hline
\end{tabular}


Continuation of the Table 8

\begin{tabular}{|c|c|c|c|}
\hline 3 & $\begin{array}{l}\text { Awareness and } \\
\text { identification } \\
\text { of skills }\end{array}$ & $\begin{array}{l}\text { General skills for social and economic needs in } \\
\text { Latvia. Identification of the client's general skills. } \\
\text { Identification of the client's individual skills. } \\
\text { Identification of the client's specific abilities. } \\
\text { Discussion. }\end{array}$ & 45 \\
\hline 4 & $\begin{array}{l}\text { Identification } \\
\text { of career } \\
\text { management } \\
\text { skills }\end{array}$ & $\begin{array}{l}\text { Career management skills. Self-confidence. } \\
\text { Research and creation skills for career } \\
\text { opportunities. Career planning skills. Decision- } \\
\text { making skills. Ability to cope with uncertainty. } \\
\text { Identification of the client's career management } \\
\text { skills. Discussion. }\end{array}$ & 45 \\
\hline 5 & $\begin{array}{l}\text { Identification } \\
\text { of presentation } \\
\text { and } \\
\text { communication } \\
\text { skills. Making } \\
\text { a plan for a job } \\
\text { interview }\end{array}$ & $\begin{array}{l}\text { Presentation skills. Presentation basics, ways of } \\
\text { preparing a presentation, making an effective } \\
\text { presentation. Communication skills. Skills to speak } \\
\text { and listen. How to prepare oneself for a job } \\
\text { interview? The nature and characteristics of a job } \\
\text { interview. Kinds of interview questions. Preparing } \\
\text { answers; analysing the most essential questions and } \\
\text { answers. Discussion. }\end{array}$ & 45 \\
\hline 6 & $\begin{array}{l}\text { Writing a CV } \\
\text { and a } \\
\text { motivation } \\
\text { letter, creating } \\
\text { an e-portfolio } \\
\text { and building up } \\
\text { computer skills }\end{array}$ & $\begin{array}{l}\text { Lecture. Writing a CV and a motivation letter. Use } \\
\text { of CV and motivation letter templates available on } \\
\text { the Internet. Use of the Europass CV template } \\
\text { (online text processing on the website } \\
\text { OpenOffice.org). What is a portfolio? The role, } \\
\text { creation and kinds of a portfolio. }\end{array}$ & 45 \\
\hline 7 & My ideal job & $\begin{array}{l}\text { Lecture. Familiarisation with work style } \\
\text { descriptions. An exercise - My ideal job and the } \\
\text { creation of an individual character puzzle according } \\
\text { to an ideal employee's character puzzle. Home } \\
\text { work. Preparing a description of job positions for } \\
\text { one's own "ideal job" based on the professional } \\
\text { standards. }\end{array}$ & 45 \\
\hline 8 & $\begin{array}{l}\text { Skills useful } \\
\text { for business, } \\
\text { opportunities } \\
\text { for distance } \\
\text { working, e- } \\
\text { mentoring }\end{array}$ & $\begin{array}{l}\text { Shaping an understanding of necessary skills for } \\
\text { entrepreneurship and employers. A fit between the } \\
\text { client's skills and personality traits for starting up } \\
\text { entrepreneurship; the identification of the potential } \\
\text { of a business. The definition of and opportunities for } \\
\text { distance working in Latvia. E-mentoring. Home } \\
\text { work. A description of a business idea in free format. }\end{array}$ & 45 \\
\hline 9 & $\begin{array}{l}\text { Designing an } \\
\text { individual } \\
\text { career plan }\end{array}$ & $\begin{array}{l}\text { An analysis of the situation in the client's career } \\
\text { development, an identification of the key ways how } \\
\text { to start up a search for a job and prepare for the job } \\
\text { that will be in a new environment and at new level. }\end{array}$ & 45 \\
\hline 10 & $\begin{array}{l}\text { Making } \\
\text { decision }\end{array}$ & $\begin{array}{l}\text { Making a decision. Choosing priorities. Simulating } \\
\text { career choice situations. A test for identifying a } \\
\text { professional crisis. }\end{array}$ & 45 \\
\hline
\end{tabular}


The Client-developing programme for career change for women in professional crisis situations was experimentally approbated on the Moodle platform; 18 randomly selected women took part in the developmental experiment. In parallel to the classes, the author organised e-counselling, which was done both via e-main and Skype. On average, the author held three counselling sessions for each participant, playing the role of a professional crisis mentor. The programme's website is available at https://karjera.gnomio.com/.

Subchapter 3.3 is entitled Approbation and expert evaluation of the Professional crisis management model. It comprises two subchapters.

Subchapter 3.3.1 is entitled Expert evaluation of the Professional crisis management model and a related methodology.

The Professional crisis management model for women was evaluated by experts. A correlation between a number of variables was identified by means of Kendall's W. Kendall's coefficient of concordance is calculated if a variable has been rated by various experts (Paura, Arhipova, 2002). Expert evaluation results for the professional crisis management model for women is shown in Table 9, calculations of the assessment of the experts'opinion consensus appear in the Formulas 1 and 2.

Table 9

\section{Expert evaluation results for the professional crisis management} model for women

Data were acquired in January 2016 from the experts who rated the model's usefulness

\begin{tabular}{|c|c|c|c|c|c|c|c|c|c|}
\hline \multirow{3}{*}{ Rating criteria } & \multicolumn{4}{|c|}{ Experts } & \multirow{3}{*}{$\mathbf{L}_{\mathbf{i}}$} & \multirow{3}{*}{$d_{i}$} & \multirow{3}{*}{$\mathbf{d}_{\mathrm{i}}{ }^{2}$} & \multirow{3}{*}{$\underset{\mathbf{R}}{\operatorname{Rank}}$} & \multirow{3}{*}{$\begin{array}{l}\text { Position } \\
\quad\left(L_{i}\right. \\
\text { rank })\end{array}$} \\
\hline & $\mathbf{A}$ & B & $\mathrm{C}$ & D & & & & & \\
\hline & \multicolumn{4}{|c|}{ Ranks $\mathbf{R}_{\mathbf{i}}$} & & & & & \\
\hline $\begin{array}{l}\text { Methodology given in the } \\
\text { model is appropriate and } \\
\text { sufficient to overcome a } \\
\text { professional crisis }\end{array}$ & 2 & 2 & 1 & 3 & 8 & -6 & 36 & 2 & I \\
\hline $\begin{array}{l}\text { The content of education in } \\
\text { the client-developing } \\
\text { programme promotes the } \\
\text { change of women's careers }\end{array}$ & 5 & 6 & 5 & 6 & 22 & 8 & 64 & 6 & III \\
\hline $\begin{array}{l}\text { Career counselling } \\
\text { techniques are sufficient in } \\
\text { the career counselling } \\
\text { process }\end{array}$ & 6 & 4 & 4 & 5 & 19 & 5 & 25 & 4.5 & II \\
\hline
\end{tabular}


Continuation of the Table 9

\begin{tabular}{|c|c|c|c|c|c|c|c|c|c|}
\hline \multirow{3}{*}{ Rating criteria } & \multicolumn{4}{|c|}{ Experts } & \multirow{3}{*}{$\mathbf{L}_{\mathbf{i}}$} & \multirow{3}{*}{$\mathbf{d}_{\mathbf{i}}$} & \multirow{3}{*}{$\mathbf{d}_{\mathrm{i}}^{2}$} & \multirow{3}{*}{$\underset{\mathbf{R}}{\operatorname{Rank}}$} & \multirow{3}{*}{$\begin{array}{l}\text { Position } \\
\quad\left(\mathbf{L}_{\mathbf{i}}\right. \\
\text { rank) }\end{array}$} \\
\hline & $\mathbf{A}$ & B & $\mathbf{C}$ & D & & & & & \\
\hline & \multicolumn{4}{|c|}{ Ranks $R_{i}$} & & & & & \\
\hline $\begin{array}{l}\text { The principle of gender } \\
\text { conformity suggested by the } \\
\text { author has all the necessary } \\
\text { dimensions }\end{array}$ & 1 & 3 & 3 & 1 & 8 & -6 & 36 & 2 & I \\
\hline $\begin{array}{l}\text { The client-developing } \\
\text { programme for career } \\
\text { change for women in } \\
\text { professional crisis situations } \\
\text { is appropriate }\end{array}$ & 4 & 5 & 6 & 4 & 19 & 5 & 25 & 4.5 & II \\
\hline $\begin{array}{l}\text { The model developed by the } \\
\text { author contributes to } \\
\text { overcoming a professional } \\
\text { crisis by women }\end{array}$ & 3 & 2 & 2 & 2 & 8 & -6 & 36 & 2 & I \\
\hline $\mathrm{n}=6$ & \multicolumn{4}{|c|}{$\mathrm{m}=4$} & $\begin{array}{c}\sum \mathrm{L}_{\mathrm{i}} \\
84\end{array}$ & 0 & \multicolumn{3}{|c|}{$\mathrm{S}=222$} \\
\hline
\end{tabular}

Notes:
A, B, C, D - experts;
$\mathrm{L}_{\mathrm{i}}$ - sum of ranks;
$d_{i}-$ rank sum minus the average value of the rank sum;
$\mathrm{d}_{\mathrm{i}}^{2}$ - squared $\mathrm{d}_{\mathrm{i}}$;
$\mathrm{R}$ - rank.

Calculations of the average value of the rank sum, $L_{\text {avg }}$,

$$
L_{\text {avg }}=\frac{\sum L_{i}}{n}=\frac{84}{6}=14
$$

where:

$\sum L_{i}-$ sum of ranks,

$\mathrm{n}$ - number of factors to be rated.

Calculations of the coefficient of concordance, Kendall's W,

where:

$$
W=\frac{12 S}{m^{2} n\left(n^{2}-1\right)}=\frac{12 \times 222}{16 \times 6(36-1)}=0.793
$$

$\mathrm{W}$ - coefficient of concordance,

$\mathrm{n}$ - number of factors to be rated,

$\mathrm{m}-$ number of experts,

$\mathrm{S}$ - sum of squared deviations.

The author put forward the following hypotheses:

$\mathrm{H}_{0}$ : no relationship among the ratings of various experts $\mathrm{W}=0$,

$\mathrm{H}_{1}$ : there is a relationship among the ratings of various experts $\mathrm{W} \neq 0$.

To verify the hypothesis (W considerably differs from zero), an equation $\mathrm{x}^{2}{ }_{\mathrm{r}}=\mathrm{m}(\mathrm{n}-1) \mathrm{W}$ was employed to compare the actual value with the critical one $\mathrm{x}_{\alpha, \mathrm{n}-1}^{2}$ (Arhipova, Paura, 2002). 
The actual value $x_{r}^{2}=n(n-1) W=4(6-1) 0.793=15.86$ was compared with the critical value $\mathrm{x}_{\alpha, 5}^{2}=11.07$.

Conclusion. The null hypothesis $\mathrm{H}_{0}$ is rejected because

$\mathrm{x}^{2}{ }_{\mathrm{r}}=\mathrm{M}(\mathrm{n}-1) \mathrm{W}>\mathrm{x}_{\alpha, 5}{ }_{\alpha, 5}=11.07$

and the alternative hypothesis $\mathrm{H}_{1}$ is accepted because there is an association among the ratings of various experts, as the $\mathrm{W}$ value considerably differs from zero.

The experts presented quite high agreement $(\mathrm{W}=0.793, \mathrm{p}=0.007)$ in rating the model (Equations 1 and 2); yet, three rating groups may be identified. The highest ratings - first place - were given to an assertion that the methodology provided by the model was appropriate and sufficient to contribute to overcoming a professional crisis, the author's principle of gender conformity involved all the necessary dimensions and the author's model helped women cope with a professional crisis. Second place was given to an assertion that the career counselling techniques were appropriate for career counselling and the client-developing programme for career change for women being in a professional crisis situation was suitable. An assertion that the content of education in the client-developing programme promoted the change of careers by women was placed in third place. Such a model of career crisis management is useful to practitioners - career counsellors -, who could use it to plan and provide career support to women being in professional crisis situations.

Subchapter 3.3.2. The subchapter is entitled Experimental results of the Client-developing programme for career change for women in professional crisis situations. It analyses the experimental data by using the adapted criteria and indicators for identifying a professional crisis, which were based on the theoretical findings made by E.F. Zeer and E.E. Simanyuk. By means of the criteria and indicators, the women self-assessed their crisis situations before doing counselling and training and after completing the client-developing programme's classes and getting a counselling session.

A study was done employing the criteria adapted by the author (Table 2) to identify a professional crisis before and after the developmental experiment, the purpose of which was to test whether the methodology suggested for overcoming a professional crisis was useful. The study's methodology was as follows: the developmental experiment's participants chose one out of five reply options that had the following scores ( 1 - fully disagree, 2 - disagree, 3 - neutral, 4 - agree, 5 - fully agree) when answering a question on their situation in their career; after completing the programme's classes, the participants repeatedly rated their situation. An analysis of the data was done based on mathematical changes in the scores. The data were compared after counting up the replies "fully agree" given by the 18 participants to a particular question before and after the developmental experiment. The results are presented in Figure 5. 
I assume an increasing number of responsibilities, more than I would ever be able to do because I cannot say "no"

In my professional work it is not clear to me what I am responsible for

I feel professional psychological and physiological changes in me and the deterioration of my health

I am not satisfied with my social and professional status

I am not satisfied with my opportunities for self-realisation in existing professional situations

I have new dominant professional values

It is difficult for me to implement my professional self-determination

I need professional self-determination

I am satisfied with my professional growth opportunities

I am satisfied with my professional preparedness

I am satisfied with my professional education

I am able to fulfil my professional intentions

A professional career is important in my life

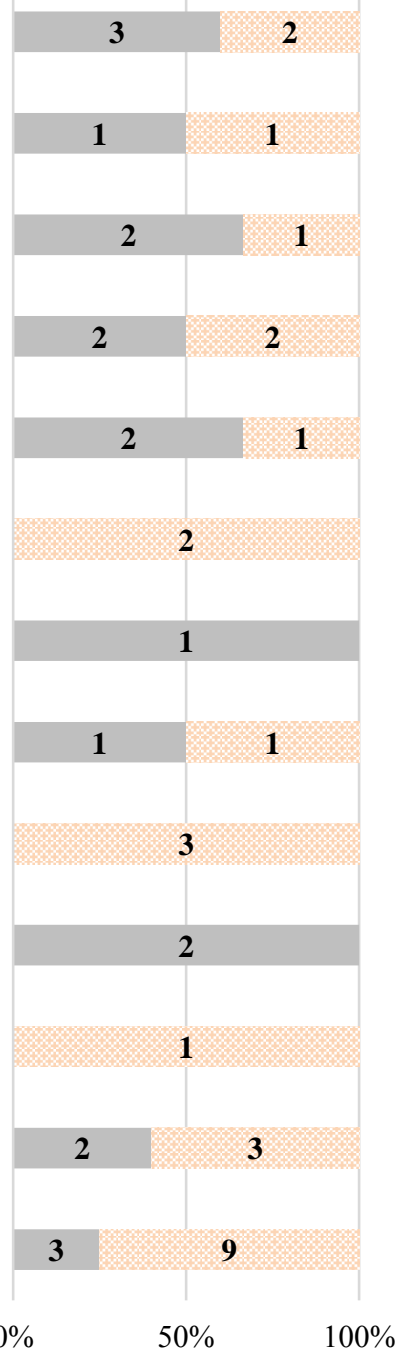

$\square$ Before experiment $\quad$ After experiment

Fig. 5. Changes in the respondents' opinions regarding the criteria and indicators for identifying a professional crisis in the result of the developmental experiment

(results are presented in absolute numbers, answers „fully agree”) Source: author's construction 
After analysing the experimental data, one can find that of 17 criteria, positive changes were observed regarding 9 criteria. The positive changes: I have new dominant professional values +2 ; I am satisfied with my professional growth opportunities +3 ; I am satisfied with my professional education +1 ; I am able to fulfil my professional intentions +1 ; A professional career in my life is important +6 . One can conclude that the women raised their self-confidence and gained positive attitude to themselves.

The author concludes that the women admitted that they coped with their crisis after successfully completing the Client-developing programme; positive changes with regard to the given criteria and indicators were identified, which evidenced that the women coped with their professional crises.

Kendall's W for the experts who evaluated the Professional crisis management model for women was $\mathrm{W}=0.793$ ( $\mathrm{p}=0.007$ ), which indicated high agreement among the experts. The methodology available within the model was appropriate and sufficient to contribute to overcoming a professional crisis owing to the training and counselling that took into consideration the factors influencing women's careers and the principle of gender conformity and employed the criteria for identifying a professional crisis.

\section{Conclusions}

The conclusions are arranged according to the research tasks set in the beginning of the doctoral thesis.

The research tasks have been performed and answers to the research questions have been given.

1. Career development for women is their self-realisation both in their career and in their family throughout the entire lifetime, given the economic, social, psychological and physical factors influencing the career. Women's careers develop owing to their lifelong learning. Lifelong education is an opportunity to educate oneself, employ oneself, expand one's horizons, be in the society and be satisfied with oneself and, consequently, to find a job appropriate for one's education and skills or start up self-employment. Based on an analysis of the findings by P. Jarvis, A. Carlsen, E. Karnītis, T. Ķoķe, I. Muraškovska, A. Ouane and V. Vilcāne, one can conclude that lifelong education together with both formal and informal education contributes to the comprehensive development of the personality and allows women to easier adapt to social changes in the new era and, if persistently enhancing their qualifications or if acquiring a new qualification, to retain their jobs or successfully do career change. The knowledge and skills acquired owing to lifelong education make significant effects on women's career development throughout the entire lifetime, as well as their integration into the labour market contributes to the national economy. As regards 
women's careers, scientific discussions have formed five approaches to women's career development: creation of specific theories on women's careers (G. Psathas, D. Zytowski); adaptation of existing theories (D. Super, J. Holland, L. Fitzgerald, L. Weitzman); creation of comprehensive theories on women's and men's careers (L. Gottfredson, $\mathrm{H}$. Astin); research on the choice of individually different careers by women (H. Farmer); creation of social cognitive models applicable to women's careers (G. Hackett, N.E. Betz, A. Bandura, R. Lent, S.D. Brown). The author believes that the social cognitive models are applicable to tackling women's professional crisis problems, where the key role is played by the idea of the individuals themselves to start changes in their careers. This means that women themselves have to be initiators that begin developing or changing their careers. The present research, which employed the factor ranking method, revealed that the respondents considered the education level, the number of vacant jobs at the place of residence, the psychological climate at the job, the management's attitude and the partner's support as the most essential factors influencing women's careers.

2. A crisis in the career of a woman usually takes the form of a professional development crisis, the causes of which could be as follows: processes related to the woman's age; professional development destructions; an identity crisis in the period of adolescence can later cause a professional crisis that manifests itself as an inability to continue the job or studies after a child's birth; an inability to change one's profession and getting into conflict with the pervious professional identity; partial professionalization - an insufficient amount of specific knowledge to acquire a desired professional status; emotional burnout that manifests itself as a change of attitude to the job and profession. Adult education supplements or replaces the basic education of adults, contributes to the build-up of their abilities, raises their professional qualifications or promotes the change of their professions, enhances their knowledge, changes their attitudes and improves behaviours, which contribute to the balanced and continuous development of the personality and his/her participation in social, economic and cultural lives. The competence of adults, the development of critical thinking in the adults and their free self-realisation are important to ensure that the adults can succeed in the labour market, which actually is the highest objective of adult education. Nowadays, an explicit trend in adult education is that professional skill development courses are the most popular, which is a prerequisite for successfully coping with a career crisis.

3. The principle of gender conformity in career counselling for women represents associations between the factors influencing women's 
careers and the situations causing a professional crisis as well as involves dimensions of this principle and criteria for identifying a professional crisis. An analysis of the results of the survey (conducted from 1 June to 18 August 2015, in which 1087 women were involved) on the principle of gender conformity that is advised to be observed in career counselling for women in crisis situations showed that the respondents appreciated self-confidence build-up (72\%), gender equality observance (66\%), stereotype elimination $(57 \%)$ and the use of communication theories $(50 \%)$. This means that the observance of the principle of gender conformity in career counselling considerably contributes to tackling career development problems for women in professional crisis situations.

4. A professional crisis is characterised as a situation in one's career when changes are necessary with regard to the choice or change of a profession or employment status. A professional crisis is caused by an inability to realise one's professional intentions, professional adaptation hardships, dissatisfaction with one's socio-professional status, problems with learning new activities and health deterioration. An analysis of the results of the survey conducted from 1 June to 18 August 2015, in which 1087 women participated, and based on the criteria for identifying a professional crisis adapted by the author and the indicators developed by E.F. Zeer (Э.Ф. Зeep) and E.E. Simanyuk (Е.Е. Симанюк) led to a conclusion that $65 \%$ of the respondents were satisfied with their professional preparedness and $60 \%$ were satisfied with their professional education; yet, a great number of them expressed dissatisfaction in their self-assessments: $57 \%$ were dissatisfied with their self-realisation opportunities in the existing professional situations; $46 \%$ were dissatisfied with their socioprofessional status; $48 \%$ felt psychic and physiological changes and health deterioration and $26 \%$ admitted they had professional deformations. Since a large number of the respondents admitted their dissatisfaction with their professional activity, which indicated crisis situations, it evidenced the need for career guidance suggested by the author in her crisis management model.

5. The professional crisis management model comprises a methodology for coping with a professional crisis through observing the principle of gender conformity in career counselling (the observance of the gender rights stipulated in the law, the application of communication theories, the elimination of stereotypes and the build-up of women's self-confidence) and through providing career education, career counselling and career guidance, thereby giving any client an opportunity to use personalised e-learning tools (e-studies, e-counselling and e-mentoring). The author considers the use of online 
career information services to be the key element of career guidance. E-counselling involves the provision of career guidance activities and services by employing all the forms of ICT: online, via phone and the Internet.

6. Eighteen randomly selected women participated in the developmental experiment when approbating the author's Client-developing programme for career change for women in professional crisis situations in the Moodle system. An analysis of the experimental data revealed that positive changes in the participants were observed for 9 criteria out of 17 . The positive changes were as follows: I have new dominant professional values +2 ; I am satisfied with my professional growth opportunities +3 ; I am satisfied with my professional education +1 ; I am able to fulfil my professional intentions +1 ; A professional career is important in my life +6 . One can conclude that the women raised their self-confidence and gained positive attitude to themselves and criteria for identifying a professional crisis may be used to determine a professional crisis during career guidance. The programme's approbation through doing a crisis identification test according to the criteria and indicators before and after the experiment revealed that all the participants experienced positive career changes in, on average, $75 \%$ of the criteria. Kendall's W=0.793 and $p=0.007$ calculated for an expert evaluation of the professional crisis management model for women showed high agreement among the experts. When educating and counselling, the methodology available in the model, which takes into account the factors influencing women's careers, the principle of gender conformity and the criteria for identifying a professional crisis, is appropriate and sufficient for coping with a professional crisis.

7. The present research has achieved the aim - career development opportunities for women in professional crisis situations were assessed; the developed and approbated Professional crisis management model for women, which includes the online Client-developing programme for career change for women in professional crisis situations, observing the principle of gender conformity, contributes to overcoming professional crisis situations.

8. The research results indicate that the theses put forward were proved:

- being aware of the most important factors for successful women's careers development and skills that can be learnt or enhanced contributes to overcoming professionals crises by the women;

- observing the principle of gender conformity in career counselling contributes to overcoming professional crises by women and to their career development; 
- the Professional crisis management model is used as a tool for promoting career development for women in professional crisis situations;

- criteria and indicators for identifying a professional crisis may be used to determine a professional crisis before and after completing the Client-developing programme for career change for women in professional crisis situations.

\section{Further research directions}

- How to ensure the development of government-funded lifelong education for adults aimed at reducing the formation of professional crisis situations.

- How to contribute to government-funded career guidance activities for women being in a crisis.

- How to enhance study programmes for career counsellors and contribute to the expansion of their activities.

\section{Proposals}

1. To create prerequisites so that a career counsellor would be available to clients at any age and any life situation - not only to the unemployed and schoolchildren but also to employed women, e.g. at crisis centres, education departments, the SEA, universities and other institutions, as well as online.

2. The State Employment Agency has to introduce ICT to a greater extent, so that counsellors would be able to follow the latest developments.

3. For women being in professional crisis situations it is advisable to use the author's the Client-developing programme for career change for women in professional crisis situations in career counselling both in the e-environment and in in-person counselling sessions, as well as to use the criteria and indicators for identifying a professional crisis to determine a professional crisis before and after completing the programm.

4. Career counsellors are advised to balance all the five life areas: the job, the family, mentality, civic activity and leisure time in order to contribute to the quality stability of professional skills.

5. It is advised to familiarise career counsellors and personnel management specialists, who daily work with the personnel, with author's Professional crisis management model for women in 
professional crisis situations and with the research results for both to identify a professional crisis for women and to promote coping with it.

6. It is advised for educational institutions and training centres to design study programmes in career education based on the research results in order to build up the most important skills needed for a successful career.

7. It is advised for employers to get familiarised with the factors influencing careers, to seek to enhance the work environment for potential employees as well as to introduce a bonus system, so that the employees feel comfortable and appreciated.

8. Women and career counsellors, as far as possible, have to use lifelong education programmes and courses to enhance their knowledge, skills and competences in order to be able to compete in the labour market.

9. Career counsellors have to enhance their career counselling techniques according to the client's interests and needs and employ quality computer technologies as well as to use e-portfolio, ementoring and e-counselling in their counselling.

10. Proposals for the State Education Development Agency:

- to promote the movement of professional crisis mentors in Latvia;

- to inform career counsellors about counselling in the e-environment; to inform clients about it in a way making them interested in it;

- to popularise opportunities to receive career services on the Internet;

- to popularise career counselling at schools, municipalities, in the mass media and, of course, among the general public;

- to hold training where a career counsellor can acquire skills and knowledge in ICT in order to be able to manage online seminars and videoconferences, e-counselling and e-mentoring;

- to educate career counsellors in the application of ICT;

- to organise the production of interactive teaching aids on career development issues for classes at schools;

- to continue developing the e-environment, which would provide career guidance, career counselling and e-counselling. 